FERNANDA VINCI KONDO

\begin{abstract}
AVALIAÇÃO DO PAPEL DOS MASTÓCITOS NA REAÇÃO INFLAMATÓRIA DESENCADEADA PELO VENENO DE BOTHROPS JARARACA EM CAMUNDONGOS GENETICAMENTE SELECIONADOS PARA ALTA OU BAIXA REATIVIDADE INFLAMATÓRIA AGUDA
\end{abstract}

Dissertação apresentada ao Programa de PósGraduação em Imunologia do Instituto de Ciências Biomédicas da Universidade de São Paulo, para obtenção do Título de Mestre em Ciências 


\section{AVALIAÇÃO DO PAPEL DOS MASTÓCITOS NA REAÇÃO INFLAMATÓRIA DESENCADEADA PELO VENENO DE BOTHROPS JARARACA EM CAMUNDONGOS GENETICAMENTE SELECIONADOS PARA ALTA OU BAIXA REATIVIDADE INFLAMATÓRIA AGUDA}

Dissertação apresentada ao Programa de PósGraduação em Imunologia do Instituto de Ciências Biomédicas da Universidade de São Paulo, para obtenção do Título de Mestre em Ciências

Área de concentração: Imunologia

Orientadora: Dra. Nancy Starobinas

Versão Original 
DADOS DE CATALOGAÇÃO NA PUBLICAÇÃO (CIP)

Serviço de Biblioteca e Informação Biomédica do

Instituto de Ciências Biomédicas da Universidade de São Paulo

(9) reprodução total

Kondo, Fernanda Vinci.

Avaliação do papel dos mastócitos na reação inflamatória desencadeada pelo veneno de Bothrops jararaca em camundongos geneticamente selecionados para alta ou baixa reatividade inflamatória aguda / Fernanda Vinci Kondo. -- São Paulo, 2016.

Orientador: Nancy Starobinas.

Dissertação (Mestrado) - Universidade de São Paulo. Instituto de Ciências Biomédicas. Departamento de Imunologia. Área de concentração: Imunologia. Linha de pesquisa: Controle genético da resposta imune.

Versão do título para o inglês: Mast cells role in Bothrops jararaca venom induced inflammation in mice genetically selected for maximum or minimum acute inflammatory reactivity

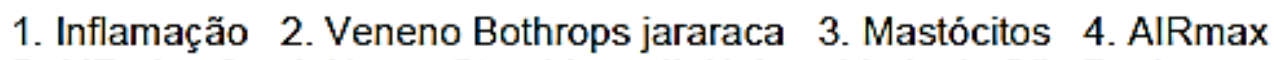
5. AlRmin 6. I. Nancy Starobinas II. Universidade de São Paulo. Instituto de Ciências Biomédicas. Programa de Pós-Graduação em Imunologia III. Título. 
Candidato(a):

Título da

Orientador(a):

\section{Fernanda Vinci Kondo.}

Avaliação do papel dos mastócitos na reação inflamatória desencadeada pelo veneno de Bothrops jararaca em camundongos geneticamente selecionados para alta ou baixa reatividade inflamatória aguda.

A Comissão Julgadora dos trabalhos de Defesa da Dissertação de Mestrado, em sessão pública realizada a ... considerou
( ) Aprovado(a)
( ) Reprovado(a)

Examinador(a):

Assinatura:

Nome:

Instituição:

Examinador(a): Assinatura:

Nome:

Instituição:

Presidente: Assinatura:

Nome:

Instituição: 


\section{Certificado}

Certificamos que o protocolo registrado sob $n^{\circ} \mathbf{1 0}$ nas fls. 15 do livro 03 para uso de animais em experimentação, sob a responsabilidade do Prof(a) Dr(a)) Nancy Starobinas, Coordenador (a) da Linha de pesquisa "Avaliação do papel dos mastócitos na reação inflamatória desencadeada pelo veneno de Bothrops jararaca em camundongos geneticamente selecionados para alta ou baixa reatividade inflamatória aguda" do qual participam o(s) aluno(s)Fernanda Vinci Kondo, está de acordo com os Princípios Éticos de Experimentação Animal adotado pela Sociedade Brasileira de Ciência de Animais de Laboratório (SBCAL) e foi aprovado pela COMISSÃO DE ÉTICA NO USO DE ANIMAIS (CEUA) em 24.03.2014, com validade de 4 anos.

São Paulo, 24 de março de 2014.
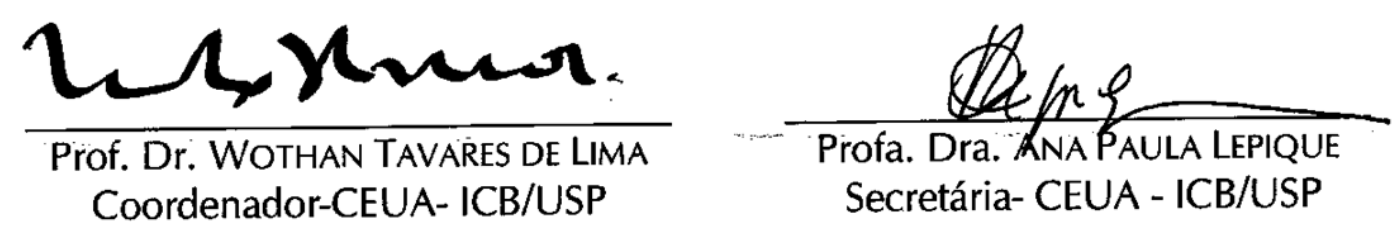


\section{COMISSÃO DE ÉTICA NO USO DE ANIMAIS (CEUAIB) INSTITUTO BUTANTAN}

\section{CERTIFICADO}

Certificamos que o projeto intitulado "Avaliaçāo do papel dos mastócitos na reação inflamatória desencadeada pelo veneno de Bothrops jararaca em camundongos geneticamente selecionados para alta ou baixa reatividade inflamatória aguda", vigente de 02/2014 a 02/2017, protocolo ${ }^{\circ} 1213 / 14$, sob a responsabilidade de Nancy Starobinas e Fernanda Vinci Kondo, Laboratório de Imunogenética - que envolve a criação e/ou utilização de animais pertencentes ao filo Chordata, subfilo Vertebrata (exceto o homem), para fins de pesquisa científica - está de acordo com os preceitos da Lei $n^{\circ} 11.794$, de 8 de outubro de 2008, do Decreto 6.899, de 15 de julho de 2009 e de normas complementares, bem como está de acordo com os Princípios Éticos na Experimentação Animal adotado pelo Colégio Brasileiro de Experimentação Animal (COBEA), e foi aprovado pela COMISSÃO DE ÉTICA NO USO DE ANIMAIS DO INSTITUTO BUTANTAN (CEUAIB).

This is to certify that the proposal "Mast cells role assessment in inflammatory reaction triggered by Bothrops jararaca venom in mice genetically selected for high or low acute inflammatory response", effective from 2014/2 to 2017/2, protocol $\mathbf{n}^{\circ} \mathbf{1 2 1 3} / 14$, under the responsibility of Nancy Starobinas and Fernanda Vinci Kondo, Laboratory of Immunogenetics - which involves the breeding and/or use of animals belonging to phylum Chordata, subphylum Vertebrata (except human beings) - has been reviewed by the Institute Butantan Animal Care and Use Committee and approved. This proposal is in accordance with standards outlined by Brazilian laws for use of experimental animals, and with ethical principles adopted by the Brazilian College of Animal Experimentation.

\begin{tabular}{|c|c|c|}
\hline Data da reunião: & $\mathbf{N}^{\circ}$ de animais/espécie & Observação \\
\hline $19 / 2 / 2014$ & $\begin{array}{c}\text { 147 Camundongos AlRmax } 25 \mathrm{~g}(\mathrm{M} / \mathrm{F}) ; \\
147 \text { Camundongos AIRmin } 25 \mathrm{~g}(\mathrm{M} / \mathrm{F})\end{array}$ & Solicitação de animais \\
\hline $19 / 2 / 2015$ & $\begin{array}{c}\text { 24 Camundongos Swiss (M); } \\
\text { 24 Camundongos Balb/c (M) }\end{array}$ & Inclusão de animais \\
\hline $8 / 3 / 2016$ & $\begin{array}{c}72 \text { Camundongos AIRmax; } \\
72 \text { Camundongos AIRmin }\end{array}$ & Adição de animais \\
\hline
\end{tabular}

São Paulo, 22 de junho de 2016

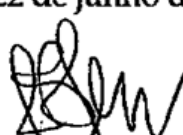

Dr. Jost R/cardo Jensen Coordenador da CEUAIB 
Dedico este trabalho ao meu Deus, pois foi Ele quem estabeleceu os meus desígnios com sua poderosa mão. 


\section{AGRADECIMENTOS}

Agradeço ao meu Senhor Jesus Cristo, por ter colocado em mim um sonho que me capacitaria a realizar. Por ter me sustentado de todas as formas possíveis, inclusive colocando em meu caminho as pessoas a seguir:

Agradeço aos meus pais, Jaime e Márcia Kondo, por nunca terem me deixado desistir. Por terem viabilizado este mestrado de tantas formas que nunca poderei agradecer até o fim. E à minha irmã, Daniela Kondo, por seu apoio e amizade, por seus conselhos de irmã mais velha de quem já passou por tudo isso e saiu vitoriosa.

Agradeço à minha orientadora, Nancy Starobinas, por estar sempre tão disponível em me ajudar. Pela amizade nos momentos difíceis, por todos os experimentos que me ensinou, pelas muitas dúvidas que me ajudou a encontrar respostas, por estar ao meu lado sempre e ter acreditado em mim desde o começo.

Agradeço também aos pesquisadores e discentes que colaboraram com o trabalho: Dra. Gisele Picolo e MSc Morena Sant'Anna, do Laboratório Especial de Dor e Sinalização (IBu), pelo experimento da dor; Dr. Anderson de Sá Nunes e MSc Bruna Bizarro, do Laboratório de Imunologia Experimental (ICB/USP), pelo experimento de citometria de fluxo; Dr. Antônio Condino e MSc Paola Vendramini, do Laboratório de Imunologia Humana (ICB/USP), pelo experimento de produção de ROS; e Dra. Eliana Faquim, do Laboratório de Imunopatologia (IBu), pelo experimento de PCA. E ao Dr. Marlos Sampaio, pelos conselhos e esclarecimentos prestados sobre envenenamento e mastócitos.

Agradeço aos brilhantes pesquisadores do Laboratório de Imunogenética, Olga Ibañez, Orlando Garcia, Marcelo de Franco, Wafa Cabrera, Solange Massa, José Ricardo Jensen, Andréia Borrego, Milene de Franco, Aryene Trezena e Solange Carbonare, sempre solícitos em sanar minhas dúvidas, ajudar em experimentos e partilhar seus conhecimentos.

Agradeço a todos os amigos que fiz no laboratório: minhas irmãs mais velhas, doutoras e do doutorado, Mara Corrêa, Tatiane Canhamero, Nathalia Laszkiewicz e Jussara Fernandes; minha irmã do meio, do mestrado, Marcela Bordenalli; e meus irmãos caçulas (alguns mais velhos do que eu), de IC e PAP (em ordem alfabética, para não dar briga), Felipe Almeida, Flávia Juscele, 
Karen Frangiotti, Letícia Monteleone, Lucyene Arrivabene, Natália Pimenta, Roberta Suene, Rosely Corrêa e Verena Gonçalves. Tem também os que passaram rapidinho por mim, Jéssica Walendy, Wherick Bernardi e Emília Rezende. E um agradecimento especial a irmã no sentido maior da palavra, Eronita Garcia. Não haveria possibilidade alguma de fazer esse mestrado sem vocês.

Agradeço também aos técnicos do laboratório e do biotério, que prepararam materiais, reagentes, animais, além de me ensinarem uma porção de coisas e de se mostrarem tão solícitos sempre que precisei.

Agradeço à banca da qualificação, Dra. Eliana Faquim, Dr. Anderson de Sá Nunes e Dra. Patrícia Clissa, pelos preciosíssimos conselhos que, certamente, enriqueceram e aperfeiçoaram esse trabalho.

Agradeço aos professores das disciplinas ministradas ao longo da pós-graduação, que deram o subsídio para que eu compreendesse com maior profundidade a imunologia, mostrando a complexidade e a beleza dessa tão amada área, e aos amigos que fiz nessas aulas, que também me agregaram conhecimento e bons momentos.

Agradeço às professoras da monitoria na USP, Lourdes Isaac, Regina D'Império, Alessandra Pontillo e Ana Paula Lepique, por terem enriquecido ainda mais o curso de mestrado, compartilhando seus conhecimentos na área da educação; e à minha colega de monitoria, Carla Longo, por ter dividido comigo as responsabilidades e alegrias desse curso.

Agradeço às agências de fomento, CAPES e FAPESP, por terem financiado esse trabalho.

Agradeço, por fim, a todos os que, indiretamente fizeram parte disso, os funcionários do Instituto Butantan e do Instituto de Ciências Biomédicas, por cuidarem das questões de secretaria e biblioteca, além de por zelarem pela segurança, alimentação e limpeza, essenciais para todo o bom trabalho.

A todos, muito obrigada. 
"Entrega ao Senhor as tuas obras, e teus desígnios serão estabelecidos".

Provérbios 16:3 


\section{RESUMO}

KONDO, F. V. Avaliação do papel dos mastócitos na reação inflamatória desencadeada pelo veneno de Bothrops jararaca em camundongos geneticamente selecionados para alta ou baixa reatividade inflamatória aguda. 2016. 91 f. Dissertação (Mestrado em Imunologia) - Instituto de Ciências Biomédicas, Universidade de São Paulo, São Paulo, 2016.

O veneno da Bothrops jararaca (VBj) causa efeitos severos como hemorragia e inflamação aguda local. Os mastócitos produzem e secretam vários mediadores que desencadeiam os eventos inflamatórios mais imediatos, como edema e dor, através de sua ação direta e do recrutamento de outras células para o sítio inflamatório. O presente trabalho tem como objetivo avaliar o papel dos mastócitos na inflamação induzida pelo VBj em linhagens de camundongos geneticamente selecionados para resposta inflamatória aguda máxima (AIRmax) e mínima (AIRmin). Grupos de animais de ambas as linhagens foram tratados durante 3 dias com o inibidor de mastócitos Cromoglicato de Sódio - CROM (20-100 mg/kg i.p.) - e receberam 1-5 $\mu \mathrm{g}$ de $\mathrm{VBj}$ (i.pl. ou i.p.). A formação de edema, a dor, a migração e ativação celular e a produção e expressão de citocinas foram avaliadas. Para avaliar o edema, os animais receberam VBj i.pl. e tiveram as patas medidas após vários horários. Animais de ambas as linhagens tiveram um aumento similar da espessura da pata e o CROM não foi capaz de inibir a formação desse edema. A dor foi mensurada através do teste com os filamentos de von Frey. Animais AIRmax apresentaram maior dor que os AIRmin em resposta ao veneno. A dor foi parcialmente inibida pelo CROM 1-6 hs após o veneno em AIRmax e 1h em AIRmin. Para avaliar a migração celular, os animais receberam VBj i.p. e tiveram suas células peritoneais coletadas após 1,3 e $24 \mathrm{hs}$. Após 3hs, os animais AIRmax apresentaram maior número de células no peritônio em relação aos AIRmin, bem como maior número de macrófagos. Após 24 hs, houve um aumento do número de neutrófilos em AIRmax, inibido por CROM. A análise por citometria de fluxo revelou que, em AIRmax, o número de mastócitos diminui após 3 e 24 hs do $\mathrm{VBj}$, enquanto que o de macrófagos aumenta. Para avaliar a ativação dessas células, foi quantificada a produção de ROS por quimiluminescência. Essa análise revelou que produção de ROS aumentou 24 hs após o veneno, sendo essa produção maior em AIRmax do que em AIRmin, e parcialmente inibida por CROM. A liberação das citocinas IL-1 $\beta$, IL-6, TNF- $\alpha$ e IL-10 foi quantificada por ELISA. Não observamos diferenças na produção destas citocinas entre as linhagens ou entre os grupos de tratamento. A análise da expressão gênica por RT-PCR dessas citocinas e das quimiocinas CCL2 e CXCL2, revelou que, após 3 hs do veneno, a expressão de IL-6 foi suprimida em ambas as linhagens, e que o CROM aumentou a expressão de IL-1 $\beta$ em AIRmin. Foi também observada uma supressão de CCL2 nos animais AIRmin sob a ação do veneno após 24 hs. Não houve diferenças de expressão de TNF- $\alpha$, IL-10 e CXCL2. Esses resultados mostram que os animais AIRmax possuem maior dor, migração de neutrófilos e macrófagos e produção de ROS que os AIRmin, e que essas reações são reduzidas quando os mastócitos são inibidos, sugerindo que a seleção genética para obtenção das linhagens, baseada na intensidade da resposta inflamatória, interferiu na reatividade dos mastócitos.

Palavras-chave: Inflamação. Veneno Bothrops jararaca. Mastócitos. AIRmax. AIRmin. 


\begin{abstract}
KONDO, F. V. Mast cella role in Bothrops jararaca venom induced inflammation in mice genetically selected for maximum or minimum acute inflammatory reactivity. $2016.91 \mathrm{p}$. Master thesis (Immunology) - Instituto de Ciências Biomédicas, Universidade de São Paulo, São Paulo, 2016.
\end{abstract}

Bothrops jararaca venom (BjV) causes severe effects such hemorrhage and acute local inflammation. Mast cells acts producing and secreting mediators that trigger the immediate inflammatory events such as edema and pain through the mediators release and the recruitment of other cells to the site of inflammation. This study aims to evaluate the role of mast cells in inflammation induced by $\mathrm{BjV}$ in mice genetically selected for maximum (AIRmax) or minimum (AIRmin) acute inflammatory response. Animals of both strains were treated during 3 days with mast cell degranulation inhibitor cromolyn - CROM (20-100 mg/Kg ip) - and received 1-5 $\mu \mathrm{g}$ of $\mathrm{BjV}$ (ipl or ip). Edema formation, pain, cell migration and activation, cytokines production and expression were evaluated. $\mathrm{BjV}$ was injected in hind paws and footpad thickness was measured after several times to evaluate the edema. AIRmax mice had similar increase in paws compared to AIRmin, and drug treatment failed to inhibit edema formation. Pain was measured with von Frey hairs, AIRmax mice exhibited greatest pain than AIRmin in response to the venom administration. The pain was partially reversed by CROM at 1-6 hs in AIRmax mice, and at $1 \mathrm{~h}$ in AIRmin. In order to analyze cell migration, animals received $\mathrm{BjV}$ ip and peritoneal cells was collected after 1, 3 and $24 \mathrm{hs}$. AIRmax mice showed higher numbers of peritoneal cells and macrophages than AIRmin after 3 hs of venom inoculation and after $24 \mathrm{hs}$, there was an increase in the number of neutrophils in AIRmax mice, which was inhibit by CROM. Decrease in the number of mast cells was observed after 3 and $24 \mathrm{hsr}$ in AIRmax when this cell population was analyzed by flow cytometry. The activation of these cells was quantified by the reactive oxygen production by chemiluminescence. Venom injection induced a higher production of ROS in AIRmax compared to AIRmin cells and was partially inhibited by the action of CROM at $24 \mathrm{hs}$ after the envenomation. The release of IL$1 \beta$, IL-6, TNF- $\alpha$ and IL-10 was quantified by ELISA. No differences in the production of these cytokines was observed between lines and treatment groups. Analyzing the gene expression by RT-PCR of these cytokines and the chemokines CCL2 and CXCL2, an inhibition of IL-6 was presented in both of lines after $3 \mathrm{hs}$ of $\mathrm{BjV}$, as well as an increase in expression of IL- $1 \beta$ by CROM in AIRmin mice. Furthermore, we observed a CCL2 inhibition in AIRmin mice $24 \mathrm{hs}$ after BjV. There was no difference in TNF- $\alpha$, IL-10 and CXCL2 expression. These results showed that AIRmax mice exhibit more hiperalgesia, macrophage and neutrophil migration, and ROS production than AIRmin mice. All these reactions are reduced when mast cells are inhibited, suggesting that the genetic selection of AIRmax and AIRmin mouse lines, based on the intensity of inflammatory response, interfered in mast cells activities.

Keywords: Inflammation. Bothrops jararaca venom. Mast cells. AIRmax. AIRmin. 


\section{LISTA DE ILUSTRAÇÕES}

FIGURA 1 - EFEITOS BIOLÓGICOS DOS COMPONENTES DOS GRÂNULOS DOS MASTÓCITOS.. . 21

FIGURA 2 - DIVERGÊNCIA PROGRESSIVA ENTRE AS LINHAGENS DE CAMUNDONGOS ........... 28

Figura 3 - AVAliaÇÃo do EdEMA deSEnCAdEAdo POR $1 \boldsymbol{\mu G}$ DE VBJ.. ................................ 46

FIGURA 4 - AVALIAÇÃo do EDEMA DESENCADEAdO POR 0,6 $\boldsymbol{\mu G}$ DE VBJ. ........................... 47

Figura 5 - AVALIAÇÃo da NOCICEPÇÃo dOS ANiMAis AIRMAX E AIRMin APós A

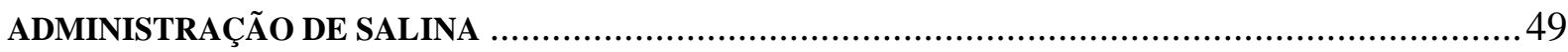

FigURA 6 - AVALIAÇÃ̃ dA NOCICEPÇÃo SOB ESTÍMULO DE VBJ (FÊMEAS).......................... 49

Figura 7 - AVAliaÇÃo da NOCICEPÇÃo SOB ESTÍMUlO dE VBJ (MACHOS)........................50

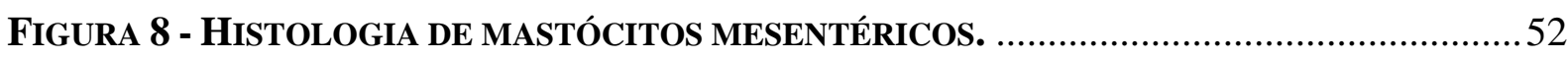

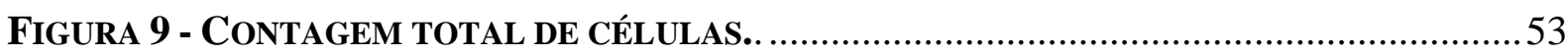

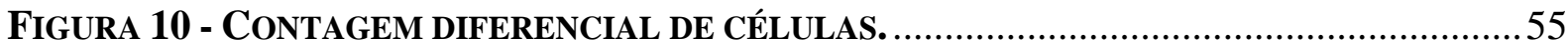

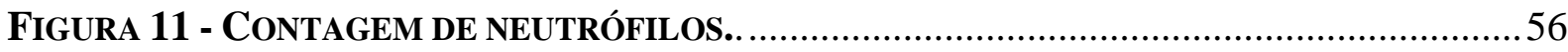

FIGURA 12 - MICROSCOPIA DE MASTÓCITOS PERITONEAIS CORADOS COM AZUL DE TOLUIDINA. 56

Figura 13 - Citograma REPRESENTATIVO dAS POPUlaÇõeS dE CÉlulas do PERITÔNIO MARCADAS PARA FCERI E CKIT.

FiguRA 14 - NÚMERO ABSOLUTO DE CÉLULAS PERITONEAIS COM O FENÓTIPO

FCERI ${ }^{+} / \mathrm{CKIT}^{+}$. 59

Figura 15 - Citograma REPRESENTATIVO dAS POPUlaÇões dE CÉlulas dO PERITÔNIO MARCADAS PARA CD3, CD11b, CD19, F4/80, GR-1 E MHC-II.

FiguRA 16 - NÚMERo ABSOLUTO de CÉluLAS PERITONEAIS COM OS FENÓTIPOS CD11B ${ }^{+}$ F4/80- /GR-1 H ${ }^{\text {IGH/MHC-II' (MACRÓFAGOS) E CD11B }}{ }^{+} /$F4/80+/GR-1 ${ }^{\text {LOw }} /$ /MHC-II $^{+}$ (NEUTRÓFILOS). 61

Figura 17 - Produção de ROS INDUZIdA PELO VBJ APÓS 3 HS.

Figura 18 - Produção de ROS INDUZIDA POR VBJ APÓs 24 HS.

FIgURA 19 - LIBERAÇÃo DE IL-1B INDUZIDA PELO VENENO. 65

FIGURA 20 - LIBERAÇÃo DE IL-6 INDUZIDA PELO VENENO. 66

FIGURA 21 - LIBERAÇÃo DE IL-10 INDUZIDA PELO VENENO. ERRO! INDICADOR NÃO DEFINIDO.

FIGURA 22 - EXPRESSÃo RELATIVA DAS CITOCINAS IL-1B E IL-6.. 68

FIGURA 23 - EXPRESSÃO RELATIVA DAS CITOCINAS DE TNF-A IL-10.

FIGURA 24 - EXPRESSÃO RELATIVA DE QUIMIOCINAS. 
Figura 25 - Reação de Anafilaxia Cutânea Passiva..

LISTA DE TABELAS

TAbela 1 - DivergênCIA de ReSPOSta ENTRE AS Linhagens ESTimuladas POR

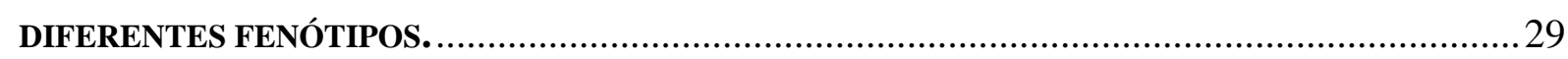

TABELA 2 - SEQUÊNCIA DOS PRIMERS DOS GENES CONSTITUTIVOS. ....................................... 42

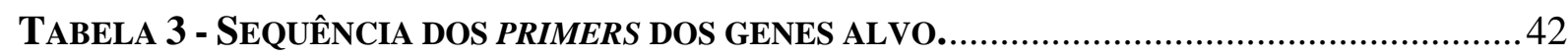

TABEla 4 - Porcentagem de desgranulaÇÃo dos Mastócitos MeSENTÉricos ........... 52 TABELA 5 - EFEITO DO TRATAMENTO DO CROM SOB A DESGRANULAÇÃo DOS MASTÓCITOS

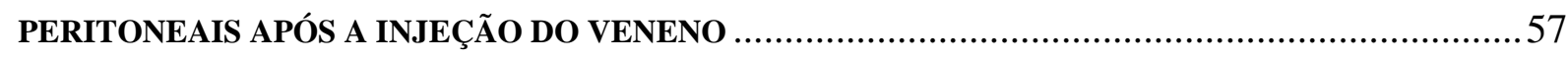




\section{LISTA DE ABREVIATURAS E SIGLAS}

\begin{tabular}{|c|c|}
\hline AIRmax & Máxima resposta inflamatória aguda \\
\hline AIRmin & Mínima resposta inflamatória aguda \\
\hline ANOVA & Análise de Variância \\
\hline$\beta 2 \mathrm{~m}$ & Beta-2-microglobulina \\
\hline BSA & Albumina de Soro Bovino \\
\hline CCL & Ligante de quimiocina $\mathrm{CC}$ \\
\hline cDNA & DNA complementar \\
\hline COX & Cicloxigenase \\
\hline CPA3 & Carboxipeptidase A3 \\
\hline CROM & Cromoglicato de Sódio \\
\hline $\mathbf{c T}$ & Cycle Threshold \\
\hline СТMC & Mastócitos de Tecido Conjuntivo \\
\hline CXCL & Ligante de quimiocina $\mathrm{CXC}$ \\
\hline DAMPs & Padrões Moleculares Associados ao Dano \\
\hline DMSO & Dimetilsulfóxido \\
\hline dNTP & Desorribonuleotídeo trifosfatado \\
\hline D.O. & Densidade Óptica \\
\hline DTT & Ditiotrietol \\
\hline EDTA & Ácido Etilenodiamino Tetra-Acético \\
\hline ELISA & Enzyme Linked ImmunonoSorbent Assay \\
\hline FACS & Fluorescent-Activated Cell Sorter \\
\hline FceRI & Receptor para a fração Fc da IgE \\
\hline $\mathrm{H}_{2} \mathrm{O}_{2}$ & Peróxido de Hidrogênio \\
\hline HPRT & Hipoxantina ribosil-transferase \\
\hline ICAM-1 & Molécula de Adesão Intercelular 1 \\
\hline Ig & Imunoglobulina \\
\hline IL & Interleucina \\
\hline I.p. & Intraperitoneal \\
\hline LD50 & Dose Letal $50 \%$ \\
\hline MDB & Membrane Desalting Buffer \\
\hline MEC & Matriz Extracelular \\
\hline MCP4 & Protease de Mastócito murino 4 \\
\hline
\end{tabular}


MMC

PBS

PCA

PGE $_{2}$

PLA2

PMA

Ppia

QTL

RIN

RNS

ROS

Rps29

RT-PCR

SBF

SVMP

TLR

TNF

Treg

URL

VBj

VCAM-1
Mastócitos de Mucosa

Tampão Fosfato Salina

Anafilaxia Cutânea Passiva

Prostaglandina $\mathrm{E}_{2}$

Fosfolipase $\mathrm{A}_{2}$

Acetato de Forbol Miristato

Peptidylprolyl Isomerase A (Cyclophilin A)

Loci de Traço Quantitativo

RNA Integrity Number

Espécies Reativas de Nitrogênio

Espécies Reativas de Oxigênio

Proteína Ribossomal S 29

Reação em Cadeia da Polimerase em Tempo Real

Soro Fetal Bovino

Metaloproteinase de veneno de serpente

Toll-like Receptor

Fator de Necrose Tumoral

Linfócito $\mathrm{T}$ regulador

Unidades Relativas de Luz

Veneno de Bothrops jararaca

Molécula de adesão vascular 1 


\section{SUMÁRIO}

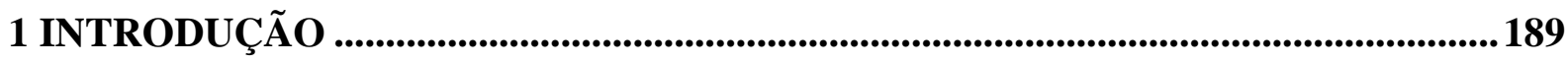

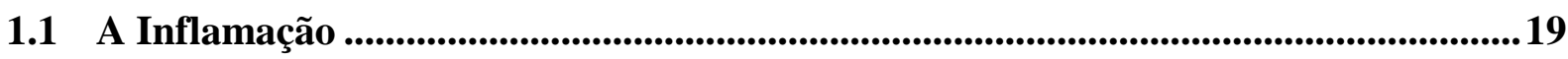

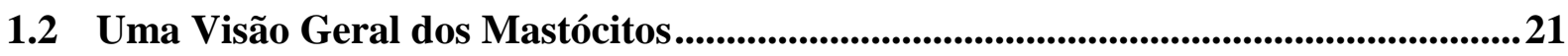

1.3 O Veneno da Serpente Bothrops jararaca......................................................................23

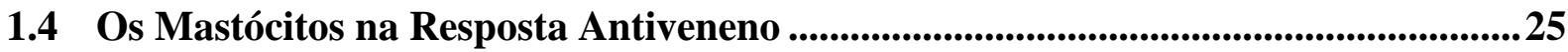

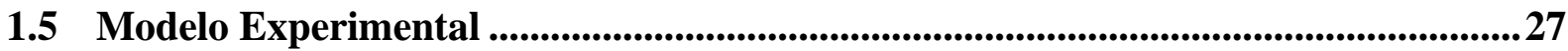

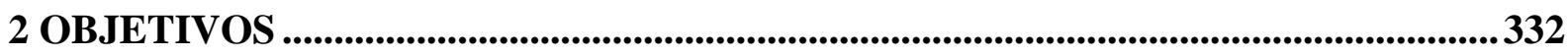

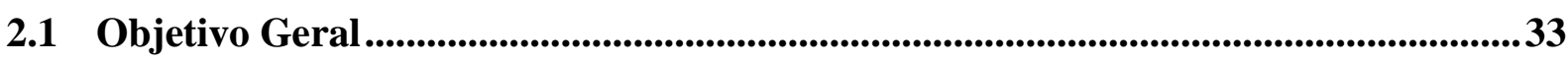

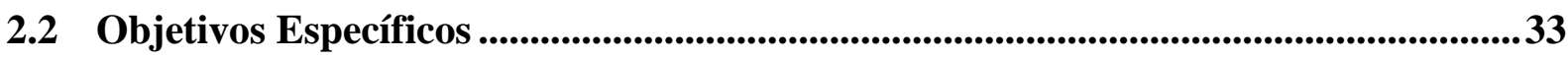

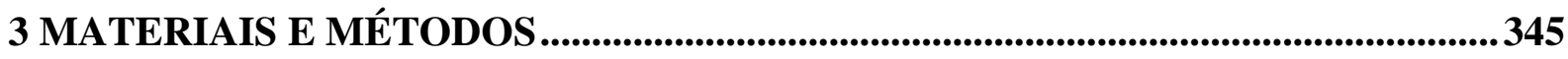

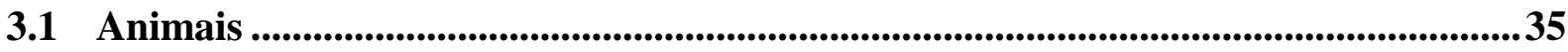

3.2 Veneno e Tratamento Farmacológico ......................................................................................35

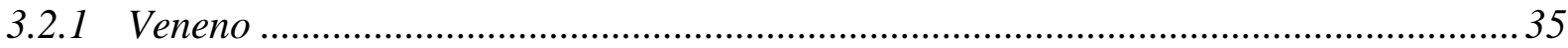

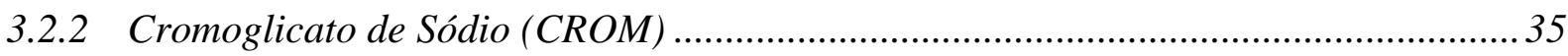

3.3 Reação Inflamatória na Cavidade Peritoneal ............................................................... 35

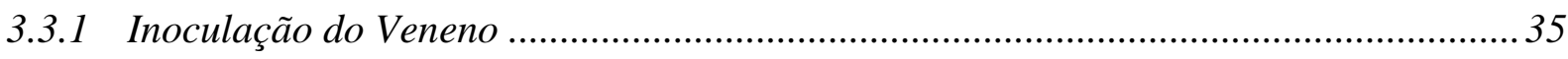

3.3.2 Obtenção e Preparação das Células Peritoneais.......................................................... 35

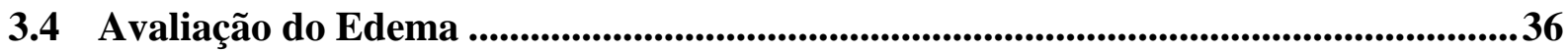

3.5 Avaliação da Nocicepção ................................................................................................................36

3.6 Avaliação da Ação Local do Cromoglicato de Sódio .......................................................337

3.7 Avaliação da Migração Celular .....................................................................................37

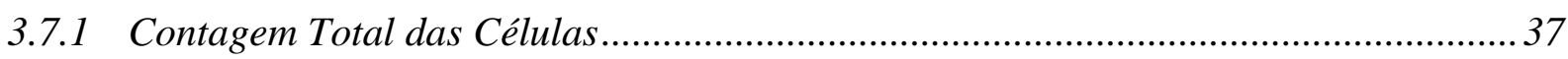

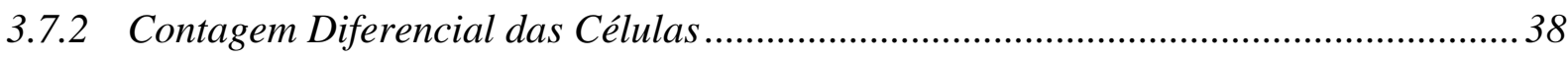

3.7.3 Avaliação das subpopulações de células no peritônio após a inoculação do veneno.. 38

3.8 Avaliação da Ativação Celular .............................................................................................39

3.9 Avaliação da Produção de Citocinas ..............................................................................39

3.10 Análise de Citocinas e Quimiocinas por Expressão Gênica ........................................ 40

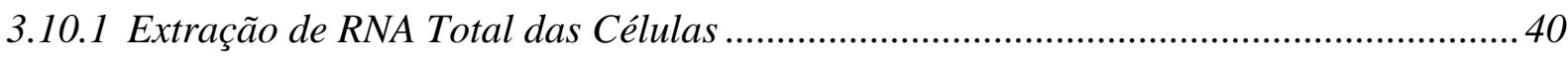

3.10.2 Síntese de DNA Complementar (cDNA) ...................................................................... 41

3.10.3 Reação de Polimerase em Cadeia em Tempo Real (RT-PCR) .................................... 41

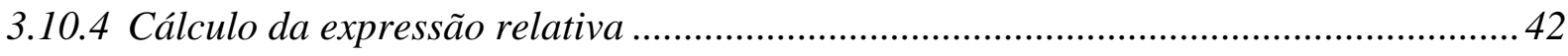

3.11 Reação de Anafilaxia Cutânea Passiva (PCA) ........................................................43 


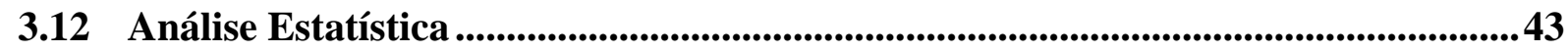

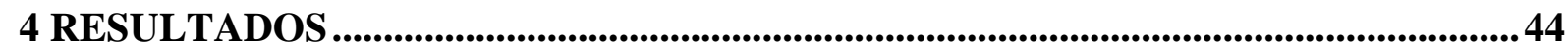

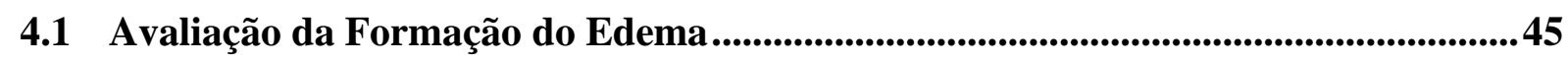

4.2 Avaliação da Nocicepção ........................................................................................................... 48

4.3 Avaliação da Ação Local do Cromoglicato de Sódio .................................................51

4.4 Avaliação da Migração Celular ..................................................................................52

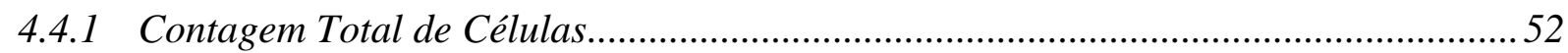

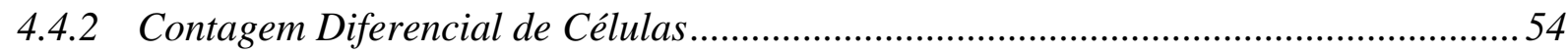

4.4.3 Avaliação das subpopulações de células no peritônio após a inoculação do veneno.. 58

4.5 Avaliação da Ativação Celular ..............................................................................62

4.6 Avaliação da Produção de Citocinas ...........................................................................64

4.7 Análise de Citocinas e Quimiocinas por Expressão Gênica ........................................ 67

4.8 Reação de Anafilaxia Cutânea Passiva (PCA) ........................................................... 71

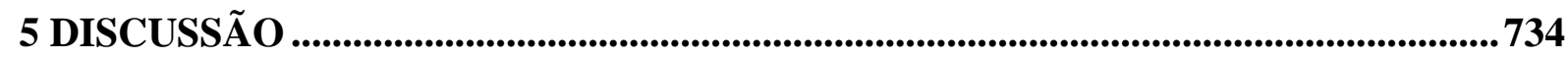

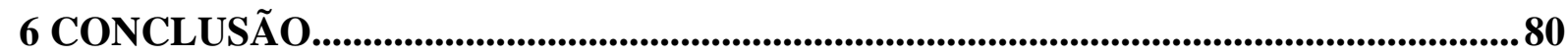

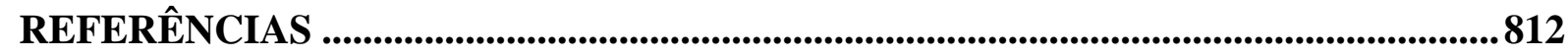




\subsection{A Inflamação}

O mecanismo de defesa natural do sistema imunológico em resposta a injúrias, toxinas e micro-organismos é a inflamação. A inflamação aguda é caracterizada pelo infiltrado de leucócitos, aumento do fluxo sanguíneo e extravasamento de proteínas plasmáticas dos vasos para o sítio da lesão (IBAÑEZ et al., 1992; PÁLMAI-PALLAG; BACHRATI, 2014). Esses eventos são caracterizados por dor, calor, rubor e edema, podendo ou não culminar em perda de função (GILROY et al., 2004).

A despeito da causa, a inflamação é uma resposta promovida pelo organismo para restaurar a homeostase, ajustando o cenário do tecido danificado para sua reconstituição. Esse evento envolve alterações funcionais da microvasculatura, levando a um coordenado recrutamento de componentes sanguíneos ao sítio da injúria, seguido por fagocitose, formação de edema e dor local (TEIXEIRA et al., 2009).

$\mathrm{Na}$ primeira linha de defesa contra danos e infecções estão os neutrófilos e os macrófagos. Além de sua atividade fagocítica, esses granulócitos produzem e liberam espécies reativas de oxigênio (ROS) e nitrogênio (RNS) através do aumento do consumo de oxigênio molecular em um processo chamado "burst oxidativo". Essas espécies desempenham um importante papel na eliminação de micro-organismos, atuando como reguladoras de outras células imunes e como moduladoras de processos apoptóticos. A produção exacerbada dessas espécies, no entanto, pode resultar na degradação de moléculas essenciais das células, como lipídios, proteínas e DNA, promovendo graves danos ao hospedeiro (DAHLGREN; KARLSSON, 1999; FREITAS et al., 2009; RIBEIRO et al., 2003).

Além dessas células, estão também presentes no sítio de infecção ou lesão os mastócitos. Uma vez que as reações da inflamação aguda estão intimamente relacionadas com os mediadores químicos derivados do tecido danificado, os mastócitos têm sido considerados potencialmente importantes na inicialização e/ou amplificação desses processos (METCALFE et al., 1997). Eles rapidamente produzem e secretam vários mediadores inflamatórios, tais como aminas vasoativas (ex.: histamina), citocinas (ex.: TNF, IL-1 $\beta$ e IL-6), fatores de crescimento, quimiocinas (ex. CXCL2), enzimas proteolíticas e mediadores lipídicos (ex.: prostaglandinas e leucotrienos), os quais desencadeiam os eventos inflamatórios mais imediatos, como o edema e a dor, através de alterações vasculares (METCALFE et al., 1997; METZ; MAURER, 2007).

O aumento da permeabilidade vascular, por exemplo, é o mecanismo primário da formação do edema, e depende diretamente da produção e/ou liberação de mediadores inflamatórios pelos mastócitos no local da injúria. (NASCIMENTO et al., 2010). Os mastócitos 
são também importantes reguladores celulares de mecanismos fisiológicos e patológicos da dor, uma vez que estão localizados próximos a neurônios nociceptivos. Eles induzem a ativação nociceptora através da liberação de mediadores químicos, como as prostaglandinas, a serotonina, a histamina e algumas citocinas (ex.: IL-1 $\beta$, IL-6 e TNF) durante a sua desgranulação (CHATTERJEA; MARTINOV, 2015; DRAY, 1995; FORSYTHE; BIENENSTOCK, 2012; REN; DUBNER, 2010).

Em alguns casos, porém, os componentes de grânulos específicos podem ter propriedades anti-inflamatórias, suprimindo os demais efeitos. É o caso da liberação de algumas quimases que, em modelos de inflamação alérgica de pulmão (WAERN et al., 2009; 2013) ou condições de neuroinflamação (HENDRIX et al., NELISSEN et al., 2013), assumem um efeito anti-inflamatório a despeito dos efeitos pró-inflamatórios gerais dos mastócitos em tais condições. $\mathrm{O}$ que se tem proposto é que essas proteases previnem os efeitos prejudiciais de níveis elevados de produtos pró-inflamatórios liberados por mastócitos, como o TNF, através da degradação de várias citocinas e quimiocinas pró-inflamatórias, tais como IL-6, IL-13, IL33, CCL2, CCL3 e CCL5 (BERAHOVICH et al., 2005; NAKAE et al., 2007; NELISSEN et al., 2013; WAERN et al., 2012; 2013; WERNERSSON; PEJLER, 2014; ZHAO et al., 2005).

Além dos mediadores da inflamação, os grânulos dos mastócitos também são constituídos por enzimas lisossomais (como a beta-hexosaminidase), proteoglicanos, proteases mastócito específicas e não-específicas e proteínas associadas a membrana dos grânulos, que possuem funções metabólicas e reguladoras (Figura 1) (WERNERSSON; PEJLER, 2014). 


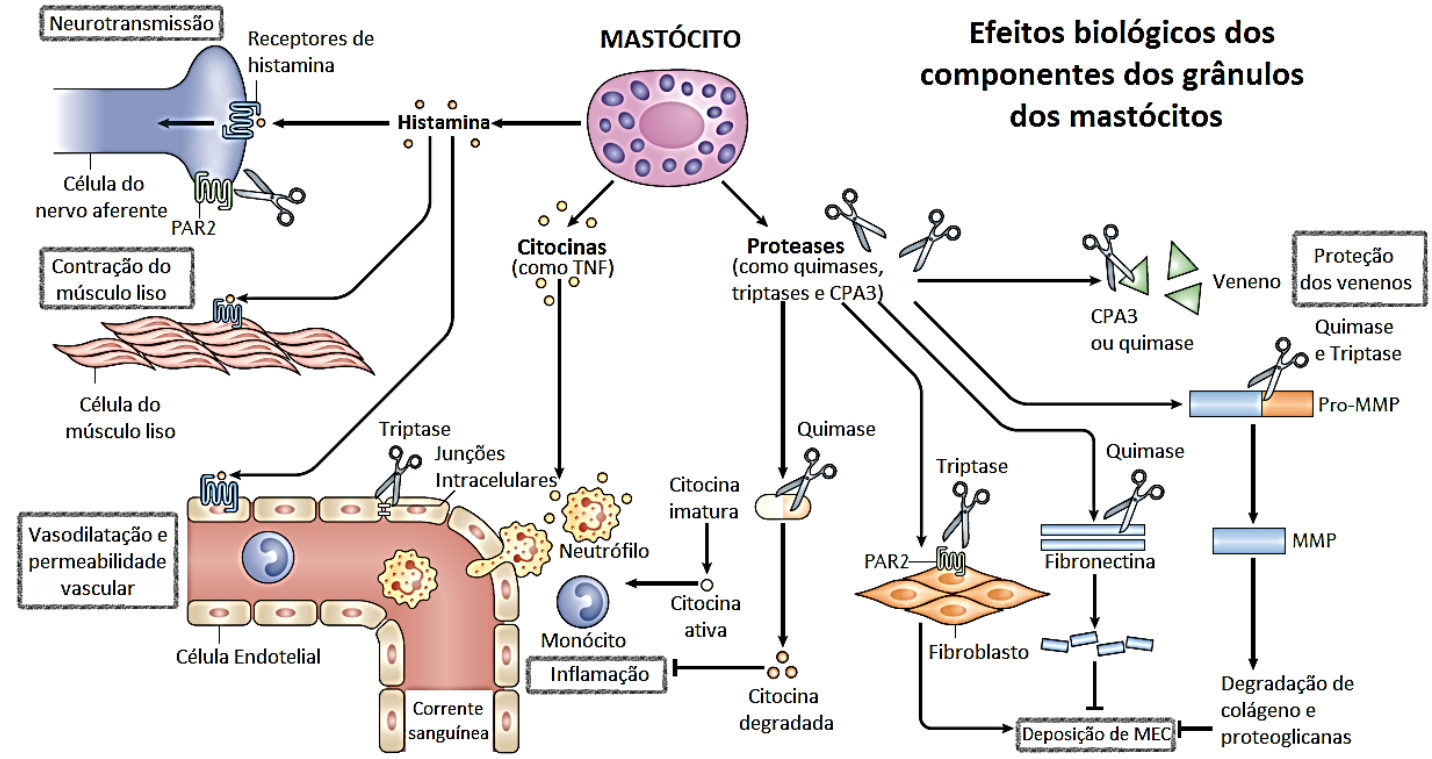

Figura 1 - Efeitos biológicos dos componentes dos grânulos dos mastócitos. Uma vez ativados, os mastócitos sintetizam e/ou liberam importantes mediadores inflamatórios, como a histamina, que participa da neurotransmissão, da contração do músculo liso, da vasodilatação e do aumento da permeabilidade vascular; as citocinas, que auxiliam na migração celular e na ativação de fagócitos; e as proteases, que promovem a deposição de MEC e auxilia na proteção contra os venenos através da degradação de seus componentes (Adaptado de WERNERSSON; PEJLER, 2014).

\subsection{Uma Visão Geral dos Mastócitos}

Os mastócitos são células hematopoiéticas oriundas de precursores pluripotentes da medula-óssea, cuja característica morfológica mais distinguível é o alto conteúdo de grânulos secretores que ocupam a maior porção do seu citoplasma. São consideradas células de vida longa, capazes de sobreviver por meses ou até anos, podendo reagir em minutos e ao longo de horas a uma variedade de estímulos físicos, biológicos e químicos com efeitos locais e sistêmicos (ABRAHAM; JOHN, 2010; MEKORI; METCALFE，2000; WERNERSSON; PEJLER, 2014).

Os precursores de mastócitos circulam pelo sangue e linfa e migram para os tecidos, onde ganham suas características morfológicas e funcionais de células maduras sob a influência de fatores do microambiente local. De modo geral, os mastócitos estão presentes em todos os tecidos vascularizados, onde residem em proximidade aos vasos sanguíneos, nervos, células do músculo esquelético, células epiteliais, glândulas produtoras de muco e folículos capilares. Estão, particularmente, concentrados em sítios anatômicos diretamente expostos ao ambiente externo como pele, vias aéreas e trato gastrointestinal (GALLI; TSAI, 2008; MEKORI; METCALFE, 2000; METCALFE et al., 1997). 
Embora os mastócitos compartilhem muitas características, eles não formam uma população homogênea, podendo diferir tanto no fenótipo quanto à funcionalidade, de acordo com a espécie animal e a sua localização. A classificação dos subtipos de mastócitos de roedores, por exemplo, é baseada em diferenças fenotípicas entre os mastócitos do tecido conjuntivo (CTMC), particularmente da pele e da cavidade peritoneal, e os mastócitos das mucosas (MMC), particularmente da lâmina própria do intestino. Além de diferir na morfologia e em características histológicas, os CTMC e MMC de ratos e camundongos ainda podem ser diferentes em aspectos bioquímicos e funcionais, incluindo a responsividade a vários estímulos de secreção e inibição por drogas, como o Cromoglicato de Sódio (ALDENBORG; ENERBACK, 1985; BIENENSTOCK et al., 1982; METCALFE et al., 1997; MILLER et al., 1989)

As informações obtidas ao longo de décadas quanto à origem, diferenciação e potencial biológico dos mastócitos sugerem que essas células são mais centrais na imunidade inata e adaptativa do que se acreditava anteriormente. Atualmente, sabe-se que os mastócitos estão envolvidos em múltiplos processos biológicos, como na fagocitose de partículas, no processamento de antígenos, na produção de citocinas, na liberação substâncias vasoativas e antimicrobicidas, no recrutamento e ativação de células inflamatórias e no reparo tecidual (ABRAHAM; JOHN, 2010; ABRAHAM; MALAVIYA, 1997; MEKORI; METCALFE, 2000).

A ativação dos mastócitos pode ser FceRI dependente, ou seja, via o receptor de alta afinidade de IgE, FceRI, que ocorre pela ligação cruzada de um antígeno multivalente (alérgeno) com seu anticorpo IgE específico ligado à membrana celular; ou FceRI nãodependente, que pode ocorrer por um estímulo não-imunogênico induzido por substâncias como neuropeptídios (ex.: substância P), compostos básicos (ex.: composto 48/80), citocinas (ex.: IL-1 e IL-3), componentes do complemento (C3a, C4a e C5a) e certas drogas (ex.: opioides), e através da ligação aos receptores de baixa afinidade de IgG (METCALFE et al., 1997).

Seja por uma ou outra via, a ativação dos mastócitos pode resultar em três tipos de efeitos biológicos: 1) secreção regulada do conteúdo de grânulos pré-formados (histamina, serotonina, proteoglicanos, proteases e citocinas) por exocitose; 2) síntese enzimática de mediadores lipídicos (metabólitos do ácido araquidônico); 3) início da transcrição, tradução e secreção de citocinas e expressão de certas quimiocinas e fatores de crescimento (GALLI; TSAI, 2008; MEKORI; METCALFE, 2000). 
Quando ativados, os mastócitos podem desgranular seu conteúdo citoplasmático através de duas vias: fragmentada ou anafilática. A desgranulação fragmentada corresponde a uma liberação seletiva de porções do conteúdo dos grânulos, sem fusão entre os grânulos ou com a membrana. Esse mecanismo foi observado desde no contexto de estresse psicossocial crônico até em resposta a estradiol, estimulação por CCL2 ou TLR e interações com $\mathrm{T}_{\text {regs }}$ (FROSSI et al., 2011; IWAMOTO et al., 2013; MCCURDY et al., 2003; VICARIO et al., 2010; YAN et al., 2014). Já na desgranulação anafilática, ocorre a liberação explosiva do conteúdo dos grânulos, ou mesmo dos grânulos inteiros, após estes se fundirem entre si e/ou com a membrana, formando o canal de desgranulação, seguido pela expulsão do grânulo. É o que ocorre, por exemplo, na ligação cruzada antígeno-FceRI (DVORAK et al., 1991; MOON et al., 2014).

Uma das abordagens utilizadas para a compreensão do papel dos mastócitos na saúde e na doença é o emprego de drogas que podem efetivamente e seletivamente inibir a função dessas células in vivo. Uma vez que os mastócitos possuem uma vasta gama de receptores tanto estimuladores, como inibidores de sua ação, compostos sintéticos têm sido manipulados para atuar em enzimas específicas ou em receptores envolvidos no processo de desgranulação, atuando, assim, como estabilizadores de mastócitos. Uma das drogas mais amplamente utilizadas é o Cromoglicato de Sódio (CROM). Embora seu mecanismo de ação não esteja totalmente elucidado, CROM tem sido clinicamente usado como uma droga antiasmática por mais de 30 anos (OKA et al., 2012; ZHANG et al., 2016).

O que se tem proposto acerca do mecanismo de ação de CROM é que ele previne indiretamente o influxo de $\mathrm{Ca}^{2+}$ por bloquear os canais de $\mathrm{Cl}^{-}$, estabilizando, assim, a membrana dos mastócitos e inibindo a sua desgranulação (LAW et al., 2011; NORRIS; ALTON, 1996). Sabe-se que a ativação dos mastócitos é intrinsecamente regulada pelo influxo e pela concentração intracelular de cálcio $\left(\mathrm{Ca}^{2+}\right)$ (RIVERA; OLIVERA, 2008). Além disso, os mediadores liberados pelos mastócitos podem ser potencializados por concentrações extracelulares de potássio $\left(\mathrm{K}^{+}\right)$ou cloreto $\left(\mathrm{Cl}^{-}\right)$(DUFFY et al., 2004; QIAN; MCCLOSKEY, 1993). Assim, bloqueadores de canais de $\mathrm{K}^{+}$e/ou $\mathrm{Cl}^{-}$podem ser capazes de reduzir indiretamente o processo de desgranulação dos mastócitos por essa via (NEMETH et al., 1990; ROMANIN et al., 1991).

\subsection{O Veneno da Serpente Bothrops jararaca}

O envenenamento por mordida de cobra é um importante problema de saúde pública em vários países do mundo, sobretudo em países tropicais e subtropicais, onde há uma grande 
diversidade de serpentes convivendo com uma população humana rural de acesso limitado a sistemas de saúde (DOS SANTOS et al., 2011).

Dos quatro gêneros de serpentes peçonhentas consideradas de interesse médico no Brasil: Bothrops, Crotalus, Lachesis e Micrurus, verifica-se o predomínio do acidente botrópico, que corresponde a aproximadamente $75 \%$ dos casos de ofidismo notificados no país. A serpente Bothrops jararaca é a espécie mais comum da região Sudeste e, uma vez que possui grande capacidade adaptativa, está distribuída em áreas silvestres, agrícolas e nas imediações das zonas urbanas (MINISTÉRIO DA SAÚDE, 2009; 2014).

Os venenos ofídicos podem ser classificados de acordo com suas ações fisiopatológicas, cujos efeitos são observados em nível local e sistêmico. A gravidade do acidente depende da quantidade de veneno inoculada, da região atingida e da espécie envolvida (MINISTÉRIO DA SAÚDE, 2009). A patogênese do envenenamento pela Bothrops envolve uma ação combinada de metaloproteinases, fosfolipases e serinoproteases, bem como a liberação de vários mediadores químicos oriundos do plasma ou de células inflamatórias da vítima (BONAVITA et al., 2006; GUTIÉRREZ; LOMONTE, 1995; TREBIEN; CALIXTO, 1989).

As metaloproteinases do veneno (SVMPs) são responsáveis pela hemorragia local. Dentre elas, a que tem sido melhor caracterizada é a jararagina, que, além de sua potente ação hemorrágica, também é capaz de processar o precursor do fator de necrose tumoral- $\alpha$ (TNF- $\alpha$ ) - uma citocina correlacionada com o desenvolvimento de dermonecrose induzida pelo veneno de Bothrops jararaca (VBj) -, bloquear a agregação plaquetária induzida por colágeno e hidrolisar fibrinogênio (CLISSA et al., 2001; FOX; SERRANO, 2005; KAMIGUTI et al., 1994; 1996; MOURA-DA-SILVA, 1996).

A Fosfolipase $\mathrm{A}_{2}\left(\mathrm{PLA}_{2}\right)$, constituinte das miotoxinas do veneno, podem induzir diretamente o dano muscular através do rompimento da integridade da membrana de células musculares esqueléticas, culminando em perda tecidual, ou indiretamente pelo processo de isquemia resultante de distúrbios vasculares (GUTIÉRREZ, 1995; GUTIÉRREZ; OWNBY, 2003; MEBS; OWNBY, 1990).

A ação das serinoproteases pode ser principalmente correlacionada à atividade semelhante à trombina do veneno, que promove alteração nos processos de coagulação sanguínea, fibrinólise, agregação plaquetária e na pressão sanguínea (MATSUI et al., 2000; SANTORO; SANO-MARTINS, 2003; SERRANO, 2013).

Dentre essas enzimas, as metaloproteinases são os componentes que mais contribuem para a inflamação local e as respostas nociceptivas induzidas pelo veneno. A ação da PLA2 se limita aos efeitos nociceptivos, enquanto que as serinoproteinases, embora não contribuam 
significativamente para as reações inflamatórias, participam ativamente dos distúrbios coagulativos desencadeados pelo VBj (ZICHAR et al., 2010).

Pode-se dizer, portanto, que o veneno da serpente Bothrops atua através de três ações principais:

- Ação proteolítica, que determina a ação inflamatória na área de inoculação do veneno por danificar a integridade vascular, induzir a necrose e estimular o recrutamento de leucócitos;

- Ação coagulante, que promove o consumo dos fatores de coagulação e a geração de produtos de degradação de fibrina e fibrinogênio, causando incoagubilidade sanguínea;

- Ação hemorrágica, que atua no endotélio vascular, provocando lesões na membrana basal dos capilares e consequente extravasamento sanguíneo (MINISTÉRIO DA SAÚDE, 2001; OLIVEIRA et al., 2010; SECRETARIA DA SAÚDE, 2015).

\subsection{Os Mastócitos na Resposta Antiveneno}

Tem sido cada vez mais reconhecido que os mastócitos são capazes de induzir e regular respostas inflamatórias em diversos cenários experimentais. Como estão estrategicamente localizados nas fronteiras entre o hospedeiro e o ambiente externo e próximo aos vasos sanguíneos, podem rapidamente responder a uma variedade de estímulos (HEIB et al., 2008; METCALFE, 1997; STASSEN et al., 2002).

Muitos componentes do veneno induzem à liberação dos mediadores dos mastócitos tais como as metaloproteinases e a $\mathrm{PLA}_{2}$, no caso do $\mathrm{VBj}-$, produzindo o aumento da permeabilidade vascular, inflamação local, dor, anormalidades dos sistemas de fibrinólise e de coagulação e choque. Dentre esses mediadores, a histamina é o principal componente liberado na resposta antiveneno, quer seja de serpentes, de insetos ou de anfíbios (BONAVITA et al.; METZ et al., 2006; WEISEL-EICHLER; LIBERSAT, 2004; WERNERSSON; PEJLER, 2014).

A histamina é o mediador inflamatório estocado em maiores quantidades nos grânulos dos mastócitos e contribui para o efeito edematogênico de alguns venenos de serpentes Bothrops sp. Esse mediador atua também nos neurônios sensoriais, produzindo prurido quando em baixas concentrações e dor quando em altas, esta última sendo uma vantagem para o predador quando o veneno é usado como defesa. Além disso, está intimamente ligada com o aumento da permeabilidade vascular, o que facilita o acesso do veneno à corrente sanguínea, contribuindo para um quadro de hipotensão e, assim, a imobilização da presa. Com isso, considera-se que a ativação dos mastócitos teciduais pode contribuir consistentemente para o 
dano tecidual local e a distribuição dos componentes do veneno (BARBOSA et al., 2003; DE FARIA et al., 2001; DRAY, 1995; HOFSTRA et al., METZ et al., 2006).

Em contrapartida, experimentos têm demonstrado que outros mediadores liberados pelos mastócitos, como as proteases, podem contribuir para a redução da morbidade e da mortalidade associadas a certos venenos através da degradação de seus componentes (GALLI;TSAI, 2008; METZ et al., 2006; NASCIMENTO et al., 2010). Dentre essas proteases, a Carboxipeptidase A e a quimase mMCP-4 têm sido mais amplamente descritas na ação contra as toxinas. A Carboxipeptidase A3 (CPA3) tem um importante papel na proteção contra a endotelina-1 e as sarafotoxinas, substâncias presentes no veneno de serpentes, inclusive da Bothrops jararaca. Já a quimase mMCP-4 se mostrou crucial para a proteção contra o veneno de algumas espécies de escorpião, bem como contra os efeitos tóxicos do peptídeo vasoativo intestinal, mostrando que a desgranulação dos mastócitos é relevante em situações em que se requer uma resposta protetora rápida a várias substâncias nocivas (BORGHERESI et al., 2001; WERNERSSON; PEJLER, 2014).

A desgranulação dos mastócitos é importante para os efeitos inflamatórios induzidos pelo veneno da serpente Bothrops moojeni, produzindo os sinais iniciais para o desenvolvimento do edema, com o envolvimento da histamina e de prostaglandinas (NASCIMENTO et al., 2010). A participação dos produtos da Ciclooxigenase (COX) na formação do edema já havia sido previamente demonstrada nos venenos de Bothrops asper (OLIVO et al., 2007), Bothrops insularis (BARBOSA et al., 2003) e também da Bothrops jararaca (OLIVO et al., 2007; TEIXEIRA et al., 1994; TREBIEN; CALIXTO, 1989), seja pela ação das prostaglandinas ou, em menor escala, pela ação dos leucotrienos.

Um estudo recente também demonstrou que os mastócitos, através da ação da histamina e, em menor escala, dos mediadores de COX, exercem um importante papel nos eventos inflamatórios induzidos pelo veneno da arraia Potamotrygon motoro. A inibição da desgranulação de mastócitos promoveu uma diminuição da formação do edema e do recrutamento de neutrófilos desencadeados pelo veneno (KIMURA et al., 2015).

Além da potente ação de seus grânulos, os mastócitos podem promover um rápido recrutamento de leucócitos. Os neutrófilos são capazes de combater agentes nocivos usando mecanismos oxidativos e não-oxidativos, enquanto que os macrófagos podem secretar matrizes de metaloproteinases e seus inibidores teciduais que regulam a deposição dos componentes de MEC e o recrutamento de células para os sítios de injúria, promovendo o reparo tecidual (DOENER et al., 2013; GALLI et al., 2011). Estudos revelam que a inflamação tecidual e o recrutamento de neutrófilos são severamente prejudicados em animais deficientes de mastócitos 
(DE FILIPPO et al., 2013; KNEILLING; ROCKEN, 2009). Por outro lado, modelos de doenças inflamatórias autoimunes severas revelam que a infiltração de neutrófilos em sítios de inflamação e destruição tecidual é também criticamente influenciada por mastócitos (BIEDERMANN et al., 2000).

O influxo de neutrófilos é dependente de mastócitos e macrófagos residentes. Ambos sintetizam os quimioatraentes de neutrófilos, CXCL1 e CXCL2 (ligantes 1 e 2 de quimiocinas CXC), sendo que uma porção dessas quimiocinas já está pré-formada nos grânulos dos mastócitos. Assim, os mastócitos, posicionados próximos à vasculatura, iniciam uma fase mais imediata do recrutamento de neutrófilos, enquanto que os macrófagos dão um maior alcance a essas células até o local da inflamação (DE FILIPPO et al., 2013). Além dessas quimiocinas, outros produtos dos mastócitos como triptases e quimases (por sua ação proteolítica) também podem atuar como quimioatraentes de neutrófilos (TANI et al., 2000; THAKURDAS et al., 2007).

$\mathrm{O}$ recrutamento de neutrófilos também pode ocorrer via linfócito $\mathrm{T}$ em reações de hipersensibilidade tardia através da ação do TNF e da quimiocina CXCL8 (IL-8), liberados pelos mastócitos, promovendo dois sinais qualitativamente diferentes, porém sinérgicos. $\mathrm{O}$ TNF induz a produção de moléculas de adesão necessárias para a ligação dos neutrófilos às células endoteliais (P-selectina, ICAM-1 e VCAM-1), enquanto a IL-8 estabelece o gradiente quimiotático necessário para a diapedese e a migração direcionada de neutrófilos (KNEILLING; ROCKEN, 2009).

Uma vez que os neutrófilos chegam até o sítio inflamatório, eles podem promover o recrutamento de monócitos e linfócitos, regulando a mudança de tipo de infiltração leucocitária durante o curso da inflamação. Além disso, podem também contribuir para a resolução de alterações tissulares causadas por vários agentes injuriantes, como venenos, através da remoção de debris, reposição ordenada de células, reparação tecidual e regeneração (TEIXEIRA et al., 2003; TIDBALL, 1995).

\subsection{Modelo Experimental}

Para investigar a participação dos mastócitos nos processos inflamatórios desencadeados pelo $\mathrm{VBj}$, foram utilizadas linhagens de camundongos geneticamente selecionados para máxima (AIRmax) ou mínima (AIRmin) resposta inflamatória aguda.

Essas linhagens de camundongos foram desenvolvidas pelo Laboratório de Imunogenética do Instituto Butantan, através de uma seleção genética bidirecional para forte 
ou fraca resposta inflamatória aguda contra partículas de poliacrilamida (Biogel P-100), uma substância não-imunogênica, insolúvel e quimicamente inerte. Esse processo seletivo foi realizado a partir de uma população inicial de camundongos altamente polimórfica (F0), oriunda da mistura equilibrada de oito linhagens isogênicas diferentes (STIFELL et al., 1987; 1990), de acordo com o esquema a seguir:

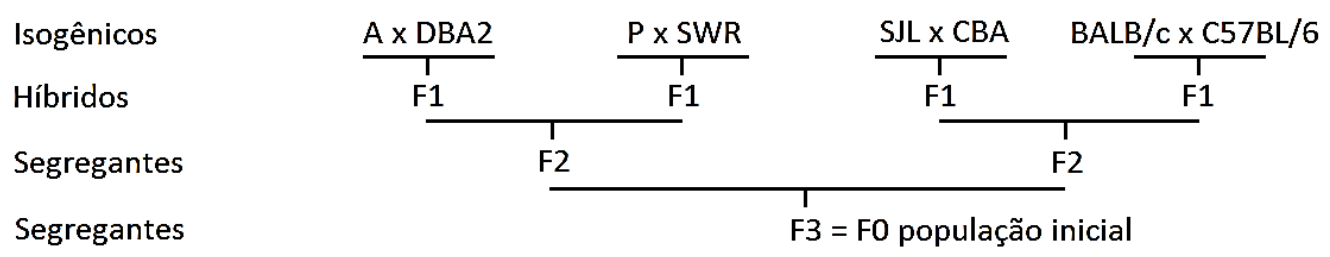

Os camundongos foram fenotipicamente selecionados baseado no influxo leucocitário local e na concentração de proteínas nos exsudatos, 24 hs após a injeção subcutânea de Biogel. Os acasalamentos foram direcionados e repetidos nas gerações sucessivas, escolhendo-se os camundongos com alta ou baixa resposta inflamatória, situados em cada um dos extremos da curva de distribuição normal dos fenótipos. A máxima separação fenotípica foi atingida com uma diferença entre as linhagens de 20 vezes do infiltrado leucocitário e 2,5 vezes da concentração de proteínas no exsudato (IBAÑEZ et al., 1992), conforme ilustrado na Figura 2.
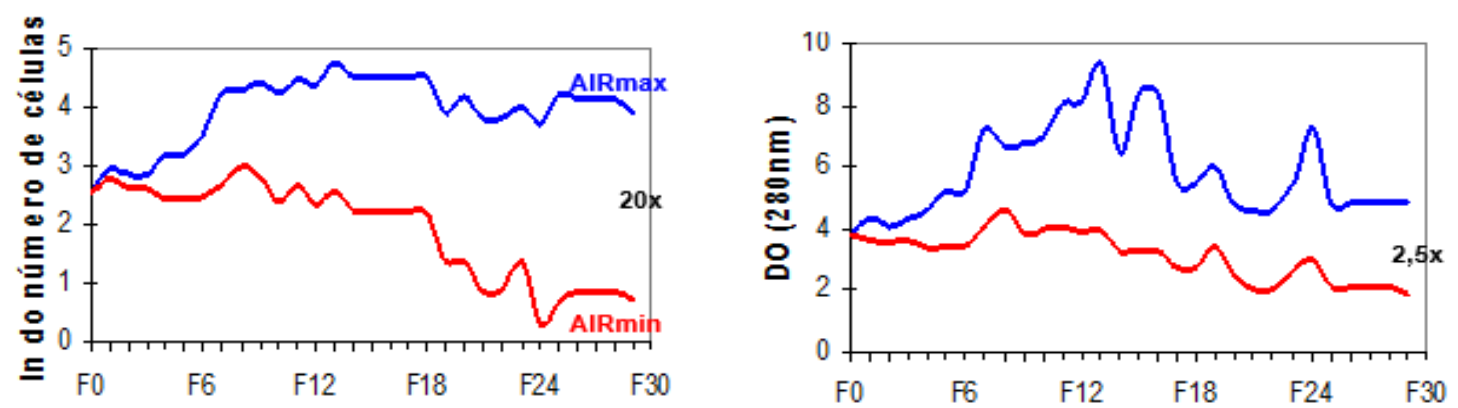

Figura 2 - Divergência progressiva entre as linhagens de camundongos selecionados para máxima ou mínima resposta inflamatória baseado no influxo leucocitário local e na concentração de proteínas nos exsudatos (IBAÑEZ et al., 1992).

Essa diferença resultou da acumulação de alelos dotados com efeitos opostos na resposta inflamatória aguda em cada linhagem. Análises desse processo seletivo indicam que a regulação da intensidade dessa resposta envolve ao menos 11 loci de traço quantitativo (QTL) - regiões 
do genoma que afetam uma característica quantitativa (BIOZZI et al., 1998; IBAÑEZ et al., 1992).

Foi recentemente demonstrado que a divergência da resposta inflamatória ao Biogel não ocorre apenas na inflamação aguda. Alguns dos genes mapeados na resposta inflamatória aguda também se apresentam diferencialmente expressos durante as reações de inflamação crônica. Além disso, diferenças no infiltrado celular e características locais do tecido analisado indicam que o processo seletivo para a resposta inflamatória aguda também afetou a resposta inflamatória crônica, o que sugere a existência de um controle genético comum para ambas as respostas (FERNANDES et al., 2016).

Além da diferença na capacidade inflamatória em resposta ao Biogel, verificou-se que estas linhagens divergem também em resposta a outros estímulos, como infecções bacterianas (ARAÚJO et al., 1998), doenças tumorais (BIOZZI et al., 1998), doenças autoimunes (VIGAR et al., 2000) e regeneração tecidual (DE FRANCO et al., 2007), como representado na Tabela 1.

Tabela 1 - Divergência de resposta entre as linhagens estimuladas por diferentes fenótipos.

\begin{tabular}{|l|c|c|c|}
\hline \multicolumn{1}{|c|}{ Fenótipo } & AlRmax & AlRmin & Ref. \\
\hline Infecções Bacterianas & Resistente & Suscetível & $\begin{array}{c}\text { ARAÚJO et al., } \\
1998\end{array}$ \\
\hline Artrite induzida por Pristane & Suscetível & Resistente & $\begin{array}{c}\text { VIGAR } \text { et al., } \\
2000\end{array}$ \\
\hline Tumorigênese de pele & Resistente & Suscetível & $\begin{array}{c}\text { BIOZZl et al., } \\
1998\end{array}$ \\
\hline Reparo tecidual & Regeneração & Cicatrização & $\begin{array}{c}\text { DE FRANCO et } \\
\text { al., 2007 }\end{array}$ \\
\hline $\begin{array}{l}\text { Reação local ao veneno de } \\
\text { B. jararaca }\end{array}$ & ++++ & + & $\begin{array}{c}\text { CARNEIRO et } \\
\text { al., 2002; } 2008\end{array}$ \\
\hline
\end{tabular}

Camundongos AIRmax e AIRmin diferem grandemente na sua resistência/suscetibilidade inata a infecção por patógenos. Araújo et al., (1998) mostraram resultados de infecção experimental por Salmonella typhimurium e Listeria monocytogenes, nos quais a dose letal (LD50) foi 100 vezes maior em camundongos AIRmax do que em AIRmin.

Avaliando-se os camundongos AIRmax e AIRmin para suscetibilidade à indução química de tumorigênese de pele, foi demonstrado que os camundongos AIRmax são mais 
resistentes a tumorigênese do que os camundongos AIRmin, apresentando uma diferença de até seis vezes na taxa indução de tumor. Com isso, evidenciou-se que uma intensa resposta inflamatória aguda (AIR) estaria associada à resistência, enquanto que uma baixa resposta, à suscetibilidade à tumorigênese nos segregados F2 (AIRmax x AIRmin) escolhidos para fenótipos extremos de AIR, o que sugere que, ao menos alguns dos QTL para essa resposta, contém genes que controlam a tumorigênese (BIOZZI et al., 1998).

Em relação a doenças autoimunes, a linhagem AIRmax mostrou ser extremamente suscetível a indução de artrite por pristane. Camundongos AIRmax tiveram 50\% de incidência de artrite 120 dias após o tratamento. A linhagem AIRmin, no entanto, mostrou ser resistente mesmo após 360 dias, excluindo-se a possibilidade de sensibilidade tardia da linhagem (VIGAR et al., 2000).

Ribeiro et al., (2003) observaram que o alto número de células inflamatórias nos animais AIRmax foi caracterizado por uma alta produção de neutrófilos na medula óssea e no sangue, alta concentração de agentes quimiotáticos em exsudatos colhidos após a indução da inflamação e uma crescente resistência dos neutrófilos infiltrados à apoptose espontânea. Assim, a seleção genética levou a uma seleção convergente de alelos, o que, consequentemente afetou a homeostase dos neutrófilos.

Esse influxo de neutrófilos mostrou-se significativamente correlacionado com o reparo tecidual, o que pode ser atribuído, ao menos em parte, a aumento da atividade das metaloproteinases de matriz e a formação de blastema (GOUREVITCH et al., 2003). Os animais AIRmax, com uma maior produção de neutrófilos, apresentaram regeneração tecidual, enquanto que, nos animais AIRmin, ocorreu cicatrização de borda (CANHAMERO et al., 2011; 2014; DE FRANCO et al., 2007).

É importante ressaltar que o processo seletivo não afetou as respostas imunes específicas, uma vez que os camundongos AIRmax e AIRmin produzem quantidades similares de anticorpos após imunização com doses ótimas de antígenos, como proteínas heterólogas e antígenos bacterianos. Respostas imunes mediadas por células, como proliferação de células T específicas e reações do tipo tardias mostraram-se igualmente similares nas duas linhagens (ARAÚJO et al.,1998; VIGAR et al., 2000).

Com relação ao $\mathrm{VBj}$, em estudos anteriores realizados com as linhagens AIRmax e AIRmin, observou-se que esses animais não apresentam alteração na dose letal (DL50) do veneno, porém são diferentes quanto a sensibilidade local, o que mostra que os fenômenos sistêmicos e locais desencadeados pelo veneno são independentes. Além disso, a linhagem AIRmax mostrou maior capacidade de resposta aguda frente ao veneno no que concerne a 
formação de edema, influxo celular, produção de citocinas e secreção de $\mathrm{H}_{2} \mathrm{O}_{2}$ (CARNEIRO et al., 2002).

Foram também investigados os mecanismos desencadeados pelo VBj que resultam na acumulação leucocitária, demonstrando uma diferença entre as linhagens de camundongos na geração de mediadores pró-inflamatórios induzidos pelo veneno. Foi verificado que os animais AIRmax secretam maiores concentrações de $\mathrm{PGE}_{2}$, bem como de IL-1 $\beta$ e IL-6 (CARNEIRO et al., 2008).

Pela capacidade das linhagens de camundongos AIRmax e AIRmin em produzir reações inflamatórias divergentes desencadeadas por agentes variados, elas foram escolhidas para o estudo da atuação dos mastócitos e dos mediadores químicos presentes em seus grânulos no processo de inflamação aguda desencadeado pelo $\mathrm{VBj}$. 
2 OBJETIVOS 


\subsection{Objetivo Geral}

Avaliar o papel do mastócito nas reações inflamatórias desencadeadas pelo veneno de B. jararaca nos animais selecionados para alta (AIRmax) ou baixa (AIRmin) resposta inflamatória aguda.

\subsection{Objetivos Específicos}

Nos animais que receberam o veneno e/ou o tratamento para inibir a atividade dos mastócitos, foram avaliados:

- O edema e a hiperalgesia;

- A migração e a ativação das células no foco inflamatório;

- A expressão e liberação das citocinas IL-1 $\beta$, IL-6, IL-10 e TNF- $\alpha$;

- A expressão das quimiocinas CCL2 e CXCL2.

A reatividade dos mastócitos dessas linhagens foi testada em uma reação anafilática e o efeito do Cromoglicato de Sódio na inibição dessa reação. 
3 MATERIAIS E MÉTODOS 


\subsection{Animais}

Foram utilizados camundongos das linhagens selecionadas para máxima (AIRmax) e mínima (AIRmin) resposta inflamatória aguda de ambos os sexos, entre 3 e 4 meses de idade, pesando, em média, 25 g. Estes animais são criados e mantidos no biotério do Laboratório de Imunogenética do Instituto Butantan (São Paulo, Brasil) em condições padrão com ração e água ad libitum e em ciclo claro/escuro de 12 hs.

Foram também utilizados animais da linhagem BALB/c, machos, pesando $20 \mathrm{~g}$, provenientes do Biotério Central do Instituto Butantan (São Paulo, Brasil).

Os procedimentos em experimentação animal foram aprovados pela Comissão de Ética no Uso de Animais (CEUA) da USP (Protocolo nº10/14) e pela Comissão de Ética no Uso de Animais do Instituto Butantan (CEUAIB) (Protocolo nº 1213/14).

\subsection{Veneno e Tratamento Farmacológico}

\subsubsection{Veneno}

Foi utilizado o veneno bruto liofilizado da serpente Bothrops jararaca, produzido e cedido pelo Laboratório de Herpetologia, Instituto Butantan (São Paulo, Brasil).

\subsubsection{Cromoglicato de Sódio (CROM)}

Os animais foram pré-tratados intraperitonealmente (i.p.) por 3 dias consecutivos com 100 mg/kg de Cromoglicato de Sódio (Sigma Chemical Co.; St. Louis, MO, USA), dissolvido em $500 \mu \mathrm{L}$ de PBS (soluções preparadas diariamente). Os experimentos foram realizados $24 \mathrm{hs}$ após a última dose da droga.

\subsection{Reação Inflamatória na Cavidade Peritoneal}

\subsubsection{Inoculação do Veneno}

Os animais foram inoculados i.p. com $500 \mu \mathrm{L}$ de uma solução contendo $5 \mu \mathrm{g}$ de VBj/camundongo diluídos em PBS. Os animais controle receberam apenas o veículo (500 $\mu \mathrm{L})$.

\subsubsection{Obtenção e Preparação das Células Peritoneais}

Para a obtenção das células peritoneais, os animais foram eutanasiados em câmara de $\mathrm{CO}_{2}$ ou por deslocamento cervical, sendo feita, em seguida, a lavagem da cavidade peritoneal com $5 \mathrm{~mL}$ de PBS ou meio RPMI 1640 gelados. As células do lavado coletado foram 
centrifugadas a $300 \mathrm{x}$ g por 5 minutos a $4{ }^{\circ} \mathrm{C}$ e submetidas a lise de hemácias com $1 \mathrm{~mL}$ de tampão de lise de hemácias [4,15 g de Cloreto de amônia, 0,84 g de Bicarbonato de Sódio e 1 $\mathrm{mL}$ de EDTA 0,5M pH 8,0 em $500 \mathrm{~mL}$ de $\mathrm{H}_{2} \mathrm{O}$ destilada] por 5 minutos em banho-maria a $37^{\circ} \mathrm{C}$. As células foram novamente centrifugadas a $300 \mathrm{x}$ g por 5 minutos, sendo, por fim, ressuspendidas em $1 \mathrm{~mL}$ de PBS ou meio RPMI 1640 suplementado com $1 \mathrm{mM}$ de Glutamina, $0,1 \mathrm{mM}$ de Gentamicina e $10 \%$ de Soro Fetal Bovino (SFB) inativado a $56{ }^{\circ} \mathrm{C}$.

\subsection{Avaliação do Edema}

Camundongos AIRmax e AIRmin foram inoculados no coxim plantar com 0,6 ou 1,0 $\mu \mathrm{g}$ de VBj/pata diluído em $30 \mu \mathrm{L}$ de salina apirogênica estéril. Como controle, foi utilizada a pata contralateral, na qual foi injetada apenas o veículo $(30 \mu \mathrm{L})$.

Antes da injeção e após 15 min., 30 min., 1, 3, 6 e 24 hs, a espessura das patas foi medida com o auxílio de um micrômetro analógico (L.S. Starrett Co.; Athol, Massachussetts, EUA). Os resultados foram calculados como a diferença entre ambas as patas e expressos como a porcentagem do aumento da espessura das patas (NASCIMENTO et al., 2010).

\subsection{Avaliação da Nocicepção}

Animais AIRmax, AIRmin e BALB/c foram inoculados no coxim plantar com 1,0 $\mu \mathrm{g}$ de $\mathrm{VBj} /$ pata diluído em $30 \mu \mathrm{L}$ de salina apirogênica estéril. Nos animais controle, foi inoculado apenas o veículo $(30 \mu \mathrm{L})$.

Para avaliação da sensibilidade mecânica foi utilizado o teste com filamentos de von Frey antes e após 30 min, 1, 3, 6, 24, 48, 72 e 96 hs após a inoculação do veneno. Foi utilizado um conjunto de vinte filamentos de náilon para medir limiares nociceptivos mecânicos (em gramas), relativos à variação progressiva de pressão. A sensibilidade tátil foi avaliada através da aplicação de um estímulo de pressão leve e constante na região central da pata, necessário para determinar a retirada, ou flinch, da pata traseira.

Os camundongos foram colocados sobre uma plataforma metálica perfurada (célula de 0,8 x $0,8 \mathrm{~cm}$.), elevada $30 \mathrm{~cm}$. da superfície, sobre a qual foi adaptada uma caixa acrílica transparente $(8 \times 8 \times 18 \mathrm{~cm}$.) dividida em doze compartimentos iguais. Antes do teste, foi permitido que os animais permanecessem nestas caixas por aproximadamente 20 minutos, até cessar a atividade exploratória.

O teste iniciou-se com um filamento de valor intermediário $(0,16 \mathrm{~g})$. Se o animal apresentou a resposta positiva ao estímulo, o próximo filamento de menor diâmetro foi testado; 
se o animal apresentou uma resposta negativa, o filamento de maior força foi testado. Este procedimento foi repetido até que o limiar fosse determinado. Cada filamento foi aplicado cinco vezes consecutivamente. O limiar nociceptivo mecânico foi definido como o filamento de menor diâmetro que provocou uma rápida retirada da pata, em pelo menos uma das cinco tentativas (TAL; BENNETT, 1994).

\subsection{Avaliação da Ação Local do Cromoglicato de Sódio}

A comprovação da eficácia do CROM para estabilização dos mastócitos em nível local em nosso modelo experimental se deu através da análise histológica da desgranulação de mastócitos mesentéricos.

Camundongos AIRmax e AIRmin foram tratados i.p. com $100 \mathrm{mg} / \mathrm{kg}$ Cromoglicato de Sódio por 3 dias consecutivos. Após 24 hs do último tratamento, os animais foram injetados i.p. com $1 \mu \mathrm{g} / \mathrm{g}$ do Composto 48/80 (Sigma), uma substância com propriedade de desgranular mastócitos e, após 30 minutos, foram eutanasiados. Semelhantemente, outro grupo de animais recebeu $5 \mu \mathrm{g}$ de VBj i.p. e, após 10 minutos, foram eutanasiados. Como controle, animais de ambas as linhagens receberam apenas o veículo $(500 \mu \mathrm{L})$ durante 3 dias e a mesma dose do Composto 48/80 e do VBj.

O abdômen foi aberto e o mesentério foi cuidadosamente removido do animal e fixado em lâmina com formaldeído por 30 minutos. As lâminas foram coradas com o azul de toluidina por 3 minutos, sendo, então, levadas ao microscópio para análise. Os mastócitos foram quantificados e classificados de acordo com a sua integridade morfológica (íntegros ou desgranulados). A análise foi expressa como a proporção (\%) de mastócitos desgranulados relativa ao número de mastócitos totais presentes no mesentério (MOTA, 1964) por $\mathrm{cm}^{2}$.

\subsection{Avaliação da Migração Celular}

Em camundongos AIRmax e AIR min, as células peritoneais foram coletadas 1, 3 e 24 hs após a injeção i.p. do VBj.

\subsubsection{Contagem Total das Células}

Uma alíquota contendo $10 \mu \mathrm{L}$ da suspensão celular obtida do lavado peritoneal foi adicionada à $180 \mu \mathrm{L}$ de PBS e $10 \mu \mathrm{L}$ de azul de tripan. As células foram contadas na câmara hemocitométrica de Malassez. Foram contadas, no mínimo, 100 células. 


\subsubsection{Contagem Diferencial das Células}

Suspensões contendo $5 \times 10^{4}$ células obtidas da coleta de lavado peritoneal foram completadas com PBS para o volume final de $300 \mu \mathrm{L}$ sendo, a seguir, centrifugadas em uma “citospin” (Eppendorf) a 10 x g por 3 minutos duas vezes. As lâminas de microscopia utilizadas foram previamente preparadas com $300 \mu \mathrm{L}$ de BSA a $4 \%$.

Após a centrifugação, as lâminas foram coradas por um conjunto para coloração rápida em hematologia (kit composto por três soluções: metanol (solução fixadora), eosina e hematoxilina) (BAXTER), e a contagem diferencial foi realizada baseada nas diferenças morfológicas e de coloração das células. Os tipos celulares considerados foram: neutrófilos, mastócitos e células mononucleares (compreendendo macrófagos e linfócitos). Foram contadas, no mínimo, 200 células por lâmina.

As amostras também foram coradas com azul de toluidina por 3 minutos. As lâminas foram levadas ao microscópio e os mastócitos foram quantificados e classificados de acordo com a sua integridade morfológica. A análise foi expressa como a proporção (\%) dos mastócitos desgranulados relativa ao número de mastócitos totais presentes no lavado peritoneal (MOTA, 1964).

\subsubsection{Avaliação das subpopulações de células no peritônio após a inoculação do veneno}

Para a análise do perfil das células presentes no peritônio após 3 e 24 hs da inoculação do veneno, foi realizada uma citometria de fluxo.

Células do lavado peritoneal foram centrifugadas, ressuspendidas em tampão de FACS (PBS 1\% SFB) e contadas. Alíquotas contendo $1 \times 10^{6}$ células foram transferidas para tubos de polipropileno de 12 × $75 \mathrm{~mm}$ (BD Biosciences) e incubadas por 30 minutos a $4{ }^{\circ} \mathrm{C}$ com os anticorpos monoclonais específicos para CD3, CD11b, CD19, cKIT, F4/80, FceRI, GR-1 e MHC-II (BD Biosciences e Biolegend), conjugados com os fluorocromos PE, BV510, APC, APC-Cy7, PB, PE-Cy7, FITC e PerCP Cy5.5, respectivamente, e em diluições apropriadas. Após lavagem, as amostras foram adquiridas no citômetro FACS Canto II, do Serviço de Citometria do Departamento de Imunologia do Instituto de Ciências Biomédicas da USP.

A análise dos resultados foi realizada através do software FlowJo® versão 10.1 (BectonDickinson). 


\subsection{Avaliação da Ativação Celular}

As células do peritônio dos animais AIRmax e AIRmin, coletadas após 3 e 24 hs da inoculação do veneno, foram avaliadas quanto a sua ativação através da quantificação da produção de ROS por um ensaio de quimiluminescência dependente de luminol (HATANAKA et al., 2006).

A técnica baseia-se na reação do luminol com as ROS geradas pelos fagócitos, produzindo uma substância que emite luz quando retorna ao seu estado basal (FREITAS et al., 2009). Os resultados foram obtidos como unidades relativas de luz (URL) e a análise foi expressa por área sob a curva.

Em uma placa branca opaca de 96 poços de fundo chato (Costar), foram acrescentados nos poços: PBS Ca ${ }^{++} / \mathrm{Mg}^{++}\left[\mathrm{CaCl}_{2} .2 \mathrm{H}_{2} \mathrm{O}(0,90 \mathrm{mM}) ; \mathrm{MgCl}_{2}(0,49 \mathrm{mM}) ; \mathrm{NaCl}(137 \mathrm{mM}) ; \mathrm{KCl}\right.$ $\left.(2,68 \mathrm{mM}) ; \mathrm{Na}_{2} \mathrm{HPO}_{4}(8,1 \mathrm{mM}) ; \mathrm{KH}_{2} \mathrm{PO}_{4}(1,21 \mathrm{mM})\right]$ q.s.p. completar o volume final de 300 $\mu \mathrm{L}$ por poço; 1 x $10^{5}$ células totais do lavado peritoneal; $30 \mu \mathrm{L}$ do substrato luminol [DMSO; PBS $\mathrm{Ca}^{++} / \mathrm{Mg}^{++}$; luminol liofilizado $\left.(100 \mu \mathrm{M})\right]$ e 2,7 $\mu \mathrm{L}$ de PMA (90 nM) (Sigma). Imediatamente após a adição do PMA, a placa foi lida em um luminômetro de microplacas (EG\&G Berthold LB96V, Bad Wildbad, Alemanha) em temperatura ambiente, com tempo de leitura total de $3600 \mathrm{~s}$, gerando, aproximadamente, 130 ciclos. Os resultados foram obtidos como unidades relativas de luz (URL) utilizando-se o programa MicroWin (Mikrotek Laborsysteme, Alemanha) e a análise foi expressa como área sob a curva, utilizandose o programa GraphPad Prism® versão 5.01 (GraphPad Software, San Diego, CA, EUA).

\subsection{Avaliação da Produção de Citocinas}

A liberação das citocinas IL-1 $\beta$, IL-6, IL-10 e TNF- $\alpha$ na cavidade peritoneal, após inoculação i.p. de VBj, foi dosada através do método ELISA, usando-se o kit BD OptEIA (BD Biosciences), segundo as instruções do fabricante para cada citocina. Foram utilizados como amostras os sobrenadantes dos lavados peritoneais.

Resumidamente, em uma placa transparente de 96 poços fundo chato (NUNCMaxisorp) foi adicionado o anticorpo de captura diluído conforme recomendação do lote em tampão carbonato ou fosfato, dependendo da citocina, para sensibilização da placa, sendo esta incubada a $4{ }^{\circ} \mathrm{C}$ overnight. Após lavagem com PBS-Tween 0,05\% (Merk), a placa foi bloqueada com PBS $20 \%$ SFB e incubada por $2 \mathrm{~h}$ em T.A. A placa foi lavada com PBS-Tween e as amostras individuais e dos recombinantes foram adicionadas e incubadas por $2 \mathrm{hs}$ em T.A. Após esse período, a placa foi mais uma vez lavada com PBS-Tween e foi adicionado o anticorpo de 
detecção biotinilado e a avidina (SAv-HRP). A reação foi revelada com a solução do substrato e bloqueada com ácido sulfúrico (H2SO4).

A placa foi lida em um leitor de ELISA automático (Labsystems Multiscan EIA), utilizando-se um filtro de $450 \mathrm{~nm}$, com correção pelo filtro de $570 \mathrm{~nm}$. Os valores de densidade óptica (D.O.) obtidos foram transformados em pg/mL mediante equação de regressão não-linear com base em uma curva padrão feita com concentrações conhecidas de cada citocina, utilizando o programa GraphPad Prism versão 5.01.

\subsection{Análise de Citocinas e Quimiocinas por Expressão Gênica}

\subsubsection{Extração de RNA Total das Células}

A extração de RNA das células peritoneais foi realizada através do uso do kit RNAspin Mini RNA Isolation (GE Healthcare), de acordo com as instruções do fabricante.

As células obtidas do lavado peritoneal foram acertadas para $5 \times 10^{6}$ células e lisadas através do uso de $350 \mu \mathrm{L}$ do tampão RA1 e 3,5 $\mu \mathrm{L}$ de $\beta$-mercaptoetanol, sendo submetidas ao vórtex por 10 segundos. O lisado foi transferido para um mini filtro RNAspin e centrifugado à $11.000 \mathrm{x}$ g por 1 minuto para ser filtrado.

Para ajuste das condições de ligação do RNA, foi adicionado ao filtrado $350 \mu 1$ de etanol $70 \%$, submetendo as amostras ao vórtex por 5 segundos duas vezes. O conteúdo foi homogeneizado três vezes e transferido para uma coluna de RNAspin e centrifugado a $8.000 \mathrm{x}$ g por 30 segundos, a fim de permitir a ligação do RNA.

A remoção do sal promove uma melhor digestão pela DNase I. Assim, para dessalinizar a membrana de sílica, foi adicionado $350 \mu \mathrm{L}$ do tampão de MDB (Membrane Desalting Buffer). As amostras foram centrifugadas a $11.000 \mathrm{x}$ g por 1 minuto para a secagem da membrana. A digestão do DNA se deu pela adição de $95 \mu \mathrm{l}$ de um preparado de $10 \mu \mathrm{L}$ de DNase I reconstituído + $90 \mu \mathrm{L}$ de tampão de reação de DNase no centro da membrana de sílica. As amostras foram incubadas à temperatura ambiente por 15 minutos.

Após a incubação, a DNase I foi inativada com $200 \mu 1$ do tampão RA2, seguida de uma centrifugação a 11.000 x g por 1 minuto. A membrana de sílica foi, então, lavada com $600 \mu \mathrm{L}$ do tampão RA3, sendo centrifugada a 11.000 x g por 1 minuto e, a seguir, com mais $250 \mu \mathrm{L}$ do tampão RA3, centrifugando a 11.000 x g por 2 minutos para secar a membrana completamente. O RNA foi eluído em $50 \mu \mathrm{L}$ de $\mathrm{H}_{2} \mathrm{O}$ livre de RNase, sendo centrifugado a 11.000 x g por 1 minuto.

A concentração dos RNAs extraídos das amostras foi mensurada por espectrofotometria 
em comprimento de onda $260 \mathrm{~nm}$ no aparelho Nanovue Plus (GE, USA) e expressa em unidades de densidade óptica (D.O.). Nesta etapa de quantificação, foi observada a relação em torno de 2.0 para a razão RNA/Proteínas $(260 \mathrm{~nm} / 280 \mathrm{~nm})$. A integridade dos RNAs foi analisada no aparelho Bioanalyser (Agilent Technologies, Alemanha). Somente os RNAs com RIN (RNA Integrity Number) superior a 8.0 foram selecionados para a obtenção de cDNA.

\subsubsection{Síntese de DNA Complementar (cDNA)}

A síntese da fita complementar de DNA foi realizada por transcrição reversa a partir do RNA total purificado.

Para tanto, $10 \mu \mathrm{L}$ contendo $0,5 \mu \mathrm{g}$ de RNA foram adicionados a $1 \mu \mathrm{L}$ de oligo (dT) (50 $\mathrm{mM}$ ), $1 \mu \mathrm{L}$ de dNTP (10 mM) (Desoxirribonucleotídeos trifosfatados) e $2 \mu \mathrm{L}$ de $\mathrm{H}_{2} \mathrm{O}$ livre de RNase. As amostras foram homogeneizadas e incubadas em um termociclador (MJ Research PTC-200) a $65^{\circ} \mathrm{C}$ por 5 minutos e a $4{ }^{\circ} \mathrm{C}$ por 1 minuto.

A seguir, foi adicionado às amostras $4 \mu \mathrm{L}$ de tampão específico $5 \mathrm{x}$ concentrado [250 $\mathrm{mM}$ Tris- $\mathrm{HCl}$ (pH 8,3), $375 \mathrm{mM} \mathrm{KCl}$ e $15 \mathrm{mM} \mathrm{MgCl} 2], 1 \mu \mathrm{L}$ de DTT (0,1 M) (dithiothreiotol) e $1 \mu \mathrm{L}$ da enzima SuperScript (200 U/ $\mu \mathrm{L}$ ) (Invitrogen). As amostras foram incubadas a $50{ }^{\circ} \mathrm{C}$ por 50 minutos. A reação da enzima foi bloqueada por uma incubação a $70{ }^{\circ} \mathrm{C}$ por 15 minutos.

\subsubsection{Reação de Polimerase em Cadeia em Tempo Real (RT-PCR)}

A fim de analisar a expressão gênica de IL-1 $\beta$, IL-6, IL-10, TNF- $\alpha$, CCL2 e CXCL2, foi realizada a reação de PCR em tempo real.

Em uma placa de 96 poços de 0,1 mL para ciclagem rápida (Applied Biosystems - Life Technologies), foi adicionado uma solução contendo sequências sintéticas específicas ou primers $(2,5 \mu \mathrm{M})(0,5 \mu \mathrm{L}$ de cada primer $), 6,25 \mu \mathrm{L}$ do Platinum SYBR Green supermix para PCR UDG com ROX (Invitrogen) e $\mathrm{H}_{2} \mathrm{O}$ livre de RNase para ajustar o volume final de 10,5 $\mu 1$ por poço. Por fim, foi adicionado a essa solução $2 \mu \mathrm{L}$ da amostra de cDNA sintetizado (diluição $1: 4)$.

As reações foram realizadas pelo termociclador Step One Plus (Applied Biosystems). As amostras foram submetidas, inicialmente, a uma fase de ativação da enzima polimerase a 95 ${ }^{\circ} \mathrm{C}$ por 10 minutos (“hot start”). A amplificação das sequências alvo ocorreu em 40 ciclos constituídos de etapas sucessivas de desnaturação $\left(95^{\circ} \mathrm{C}\right.$ por 15 segundos) e extensão $\left(60^{\circ} \mathrm{C}\right.$ por 1 minuto). A fluorescência do SYBR Green incorporada ao material dupla fita amplificado a cada ciclo foi detectada na etapa da extensão pelo termociclador. 
Os resultados foram analisados através do programa Step One versão 2.3 e a cada amostra foi atribuído um valor de cT (Cycle Threshold) referente ao número de ciclos necessários para que a fluorescência incorporada às duplas fitas amplificadas ultrapassasse a fluorescência de fundo das reações, ou seja, no início da fase Log de amplificação das sequências alvo.

As sequências dos primers utilizados foram desenhadas com o programa Primer Blast, disponível em: < http://www.ncbi.nlm.nih.gov/tools/primer-blast/index.cgi >, estando representadas nas Tabelas 2 e 3:

Tabela 2 - Sequência dos primers dos genes constitutivos.

\begin{tabular}{|c|l|l|}
\hline PRIMER & FORWARD & REVERSE \\
\hline Ppia & AGCGTTTTGGGTCCAGGAAT & AAATGCCCGCAAGTCAAAAG \\
\hline $\mathbf{3 2 m}$ & CCCCACTGAGACTGATACATACG & CGATCCCAGTAGACGGTCTTG \\
\hline HPRT & CACAGGACTAGAACACCTGC & GCTGGTGAAAAGGACCTCT \\
\hline $\mathbf{R p s} \mathbf{2 9}$ & TCTACTGGAGTCACCCACGGAAGT & GTCAGTCGAATCCATTCAAGGTCGC \\
\hline
\end{tabular}

Tabela 3 - Sequência dos primers dos genes alvo.

\begin{tabular}{|c|l|l|}
\hline PRIMER & FORWARD & REVERSE \\
\hline IL-1 $\boldsymbol{\beta}$ & AGATGAAGGGCTGCTTCCAAACC & TTGTTGATGTGCTGCTGCGAGA \\
\hline IL-6 & GTTCTCTGGGAAATCGTGGA & TGTACTCCAGGTAGCTATGG \\
\hline IL-10 & GCTGGACAACATACTGCTAACC & CCCAAGTAACCCTTAAAGTCCTG \\
\hline TNF- $\boldsymbol{\alpha}$ & TCTCATCAGTTCTATGGCCC & GGGAGTAGACAAGGTACAAC \\
\hline $\mathbf{C C L 2}$ & GCCTGCTGTTCACAGTTGC & TCATTGGGATCATCTTGCTG \\
\hline $\mathbf{C X C L 2}$ & CCTGGTTCAGAAATCATCCA & CTTTGGTTCTTCCGTTGAGG \\
\hline
\end{tabular}

\subsubsection{Cálculo da expressão relativa}

A expressão dos genes estudados foi estimada por meio do método comparativo do cT.

Pequenas variações relativas às diferenças na quantidade do RNA total dos genes alvo foram corrigidas por normalização. Para tanto, foram testados quatro primers de genes constitutivos, sendo eles: Ciclofilina (Ppia), Beta-2- microglobulina ( $\beta 2 \mathrm{~m})$, Hipoxantina ribosil-transferase (HPRT) e Proteína Ribossomal S 29 (Rps29). Através de cálculos 
algorítmicos realizados pela ferramenta GeNorm - Excel, foi determinado o fator de normalização de expressão dos genes, indicando como genes mais estáveis para a análise das células peritoneais os genes Ppia e HPRT.

Pelos valores do cT, foi calculado o Delta $\mathrm{cT}(\Delta \mathrm{cT})$ para cada amostra de cDNA, que consiste na diferença entre o cT do gene de interesse e do gene constitutivo ( $\Delta \mathrm{cT}=\mathrm{cT}<$ gene alvo> - cT <gene constitutivo>). A expressão dos genes entre os vários grupos experimentais foi determinada pela comparação entre o $\Delta \mathrm{cT}$ das amostras em diferentes condições experimentais e o $\Delta \mathrm{cT}$ do grupo controle (calibrador) $(\Delta \Delta \mathrm{cT}=\Delta \mathrm{cT}<$ teste $>-\Delta \mathrm{cT}$ <calibrador>). $\mathrm{O}$ valor da expressão relativa foi considerado, portanto, o resultado da fórmula $2^{-\triangle \Delta C T}$ (LIVAK ; SCHMITTGEN, 2001).

\subsection{Reação de Anafilaxia Cutânea Passiva (PCA)}

Camundongos das linhagens AIRmax, AIRmin e BALB/c de, aproximadamente, 4 semanas de idade foram injetados i.d. na região dorsal, sob sedação $(100 \mathrm{mg} / \mathrm{kg}$ Quetamina e $10 \mathrm{mg} / \mathrm{kg}$ de Xilazina), com diferentes concentrações de soro de animais imunizados com Ovalbumina (1:80, 1:160, 1:320 e 1:640), tendo como controle a injeção do soro de um animal não imunizado. Após o período de sensibilização de $2 \mathrm{hs}$, os animais foram desafiados intravenosamente com $500 \mu \mathrm{L}$ de uma solução composta pelo corante azul de Evans (Sigma) a 0,25\% e Ovalbumina ( $2 \mathrm{mg} / \mathrm{mL}$ ). Passados 30 minutos do desafio, os camundongos foram eutanasiados em câmara de $\mathrm{CO}_{2}$ e a leitura da reação foi analisada na pele invertida dos animais. Foram consideradas reações positivas as que obtiveram, no mínimo, $5 \mathrm{~mm}$ de diâmetro (OVARY, 1958).

\subsection{Análise Estatística}

As diferenças entre os grupos experimentais foram analisadas estatisticamente por análise de variância (One-Way ANOVA), seguida do teste de Bonferroni. Foram considerados significativos os valores de $\mathrm{p}<0,05$, empregando-se o programa GraphPad Prism versão 5.01. 
4 RESULTADOS 


\subsection{Avaliação da Formação do Edema}

Para avaliar o papel dos mastócitos na formação do edema promovido pelo VBj, camundongos pré-tratados com diferentes doses de CROM foram inoculados com o VBj no coxim plantar e a espessura das patas foi medida. Os resultados foram calculados como a diferença entre a pata inoculada com o veneno e a pata controle, e expressos como a porcentagem do aumento da espessura das patas (NASCIMENTO et al., 2010).

A injeção de $1 \mu \mathrm{g}$ de VBj na pata dos animais de ambas as linhagens promoveu um aumento de espessura superior a 40\%. Nos animais da linhagem AIRmax, a espessura da pata inoculada aumentou até a $1^{\mathrm{a}}$ hora após o veneno, retornando a sua espessura inicial nas horas subsequentes. Já nos animais AIRmin, a espessura da pata aumentou até a $3^{\mathrm{a}}$ hora, retornando ao nível basal. Não houve diferença significativa entre as linhagens (Figura 3A).

O pré-tratamento dos animais com as doses de 20 e $30 \mathrm{mg} / \mathrm{kg}$ de CROM não inibiu a formação do edema desencadeado pelo VBj em nenhuma das linhagens. Foram, então, testadas as doses de 50 e $100 \mathrm{mg} / \mathrm{kg}$ de CROM, porém estas também não foram capazes de inibir o edema (Figura 3B-C).

Uma vez que não foi possível modular a formação do edema com o pré-tratamento com CROM, foi diminuída a dose do veneno de $1 \mu \mathrm{g}$ para $0,6 \mu \mathrm{g} /$ pata.

A injeção de 0,6 $\mu \mathrm{g}$ de $\mathrm{VBj}$ na pata dos animais promoveu um aumento da espessura das patas superior a 30\% em ambas as linhagens. A espessura da pata aumentou até 3 hs após a inoculação o veneno em AIRmax e até 6 hs em AIRmin, diminuindo nas horas seguintes. Mais uma vez, não houve diferença significativa entre as linhagens (Figura 4A). O prétratamento com $100 \mathrm{mg} / \mathrm{kg}$ de CROM não foi capaz de modular a formação do edema promovida por essa dose de $\mathrm{VBj}$ em nenhuma das linhagens (Figura 4B-C). 


\section{Edema de pata - $1 \mu \mathrm{g} \mathrm{VBj}$}
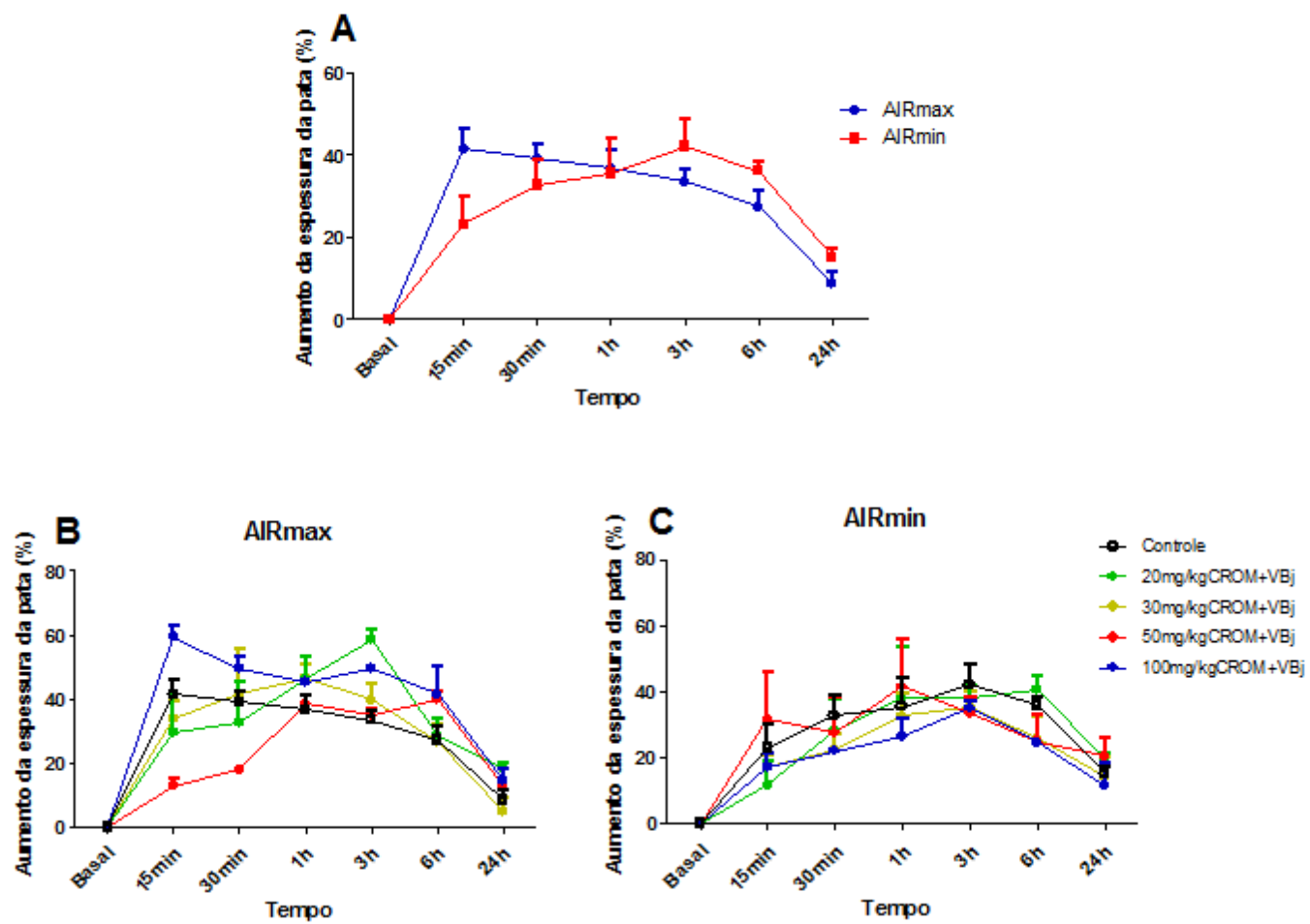

Figura 3 - Avaliação do edema desencadeado por $1 \boldsymbol{\mu g}$ de VBj. Animais de ambas as linhagens (n=6) foram inoculados no coxim plantar com $\mathrm{VBj}$ e o aumento da espessura da pata foi medido (A). Foi também mensurado o edema nos animais AIRmax (B) e AIRmin (C) tratados com as diferentes doses de CROM (n=3-6). Os resultados representam a média \pm e.p.m. 
Edema de pata - 0,6 $\mu \mathrm{g}$ VBj
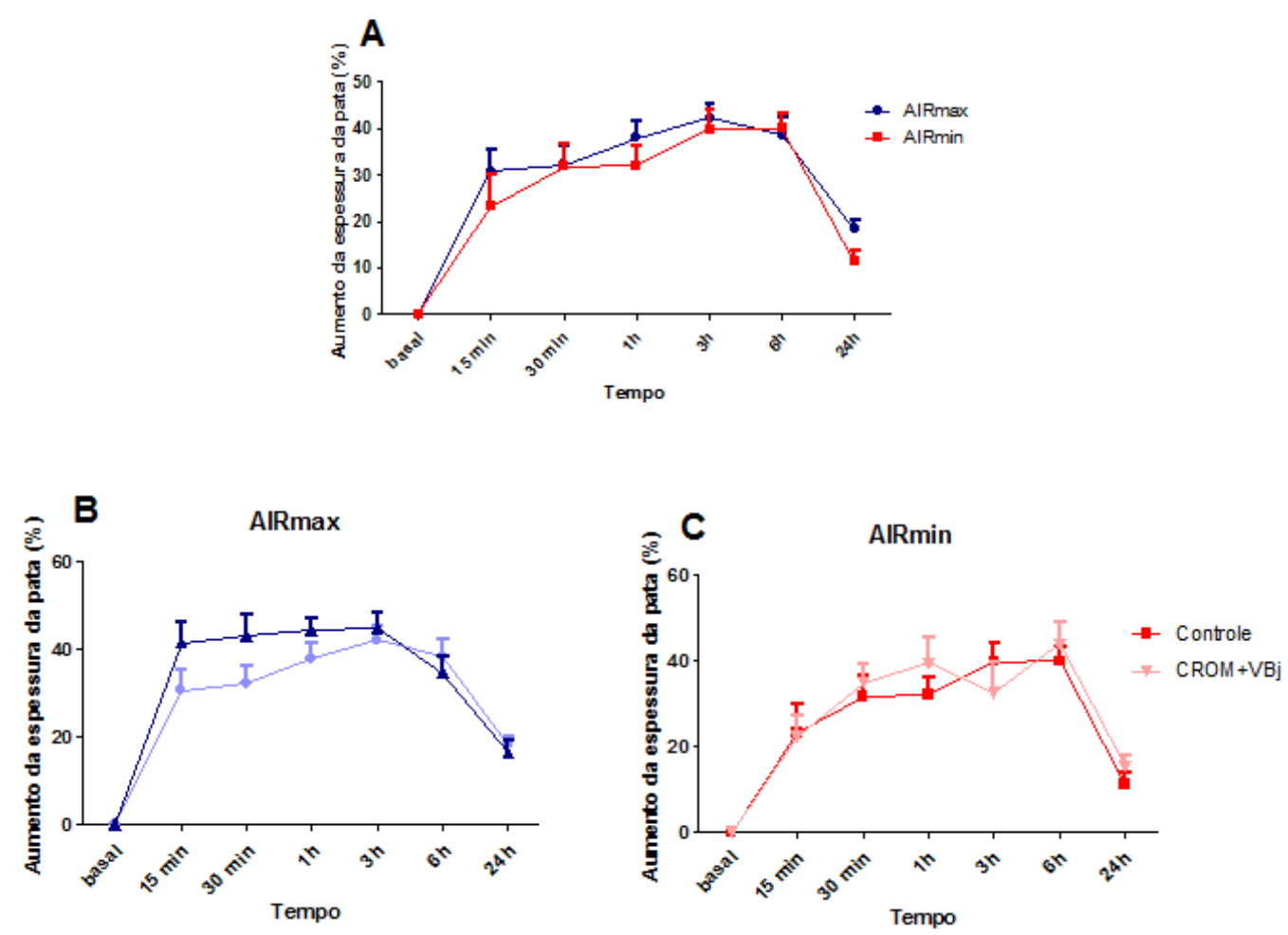

Figura 4 - Avaliação do edema desencadeado por 0,6 $\boldsymbol{\mu g}$ de VBj. Animais de ambas as linhagens $(n=10)$ foram inoculados no coxim plantar com VBJ e o aumento da espessura da pata medido (A). Foi também mensurado o edema nos animais AIRmax (B) e AIRmin (C) tratados com $100 \mathrm{mg} / \mathrm{kg}$ de CROM (n=8). Os resultados representam a média \pm e.p.m. 


\subsection{Avaliação da Nocicepção}

Para avaliar o papel dos mastócitos na nocicepção sob o estímulo do VBj, testamos a sensibilidade dos animais através do teste com filamentos de von Frey. Foi utilizado um conjunto de filamentos de náilon para medir limiares nociceptivos mecânicos relativos à variação progressiva de pressão. A sensibilidade tátil foi avaliada através da aplicação de um estímulo de pressão leve e constante na região central da pata, necessário para determinar a retirada, ou flinch, da pata traseira. Quanto menor o limiar nociceptivo, maior a dor dos animais.

A medição dos animais controle após a administração do veículo revelou que os animais AIRmax já possuem um limiar nociceptivo menor do os animais AIRmin (Figura 5).

A injeção do VBj na pata $(1 \mu \mathrm{g})$ promoveu uma diminuição significativa do limiar nociceptivo nas duas linhagens, sendo essa diminuição maior em AIRmax do que em AIRmin. O menor limiar ocorreu entre 3 e 6 hs a partir da inoculação do veneno em AIRmax e às 6 hs em AIRmin. O pré-tratamento com CROM (100 mg/kg) inibiu parcialmente o limiar nociceptivo dos 15 minutos às 24 hs nos animais AIRmax e à 1 h nos AIRmin (Figura 6).

Uma vez que não há dados na literatura de avaliação de nocicepção nos camundongos das linhagens AIRmax e AIRmin, utilizamos a linhagem BALB/c como referência para o experimento. Para verificar também se alguma interferência hormonal pode ter participado no resultado do experimento anterior pela utilização de camundongos fêmeas, utilizamos camundongos machos.

Nestes animais, a injeção de VBj na pata $(1 \mu \mathrm{g})$ também promoveu a diminuição do limiar nociceptivo nas três linhagens, sendo essa diminuição maior em AIRmax do que em AIRmin a partir das 3 hs e maior que BALB/c a partir das $24 \mathrm{hs}$. Os animais BALB/c atingiram um limiar nociceptivo semelhante aos AIRmax ao longo do tempo, porém retornaram ao seu nível basal mais rapidamente. Os animais AIRmax e BALB/c atingiram seu menor limiar às 3 hs, enquanto que os AIRmin, aos 30 minutos e $1 \mathrm{~h}$. O pré-tratamento com CROM (100 mg/kg) inibiu parcialmente a diminuição do limiar nociceptivo entre 1 e 6 hs em AIRmax, à $1 \mathrm{~h}$ em AIRmin e dos 30 minutos à 1 h em BALB/c. Nas três linhagens, os grupos controles sem tratamento e os tratados apenas com CROM permaneceram em seus níveis basais de dor, sem diferenças significativas entre eles (Figura 7). 


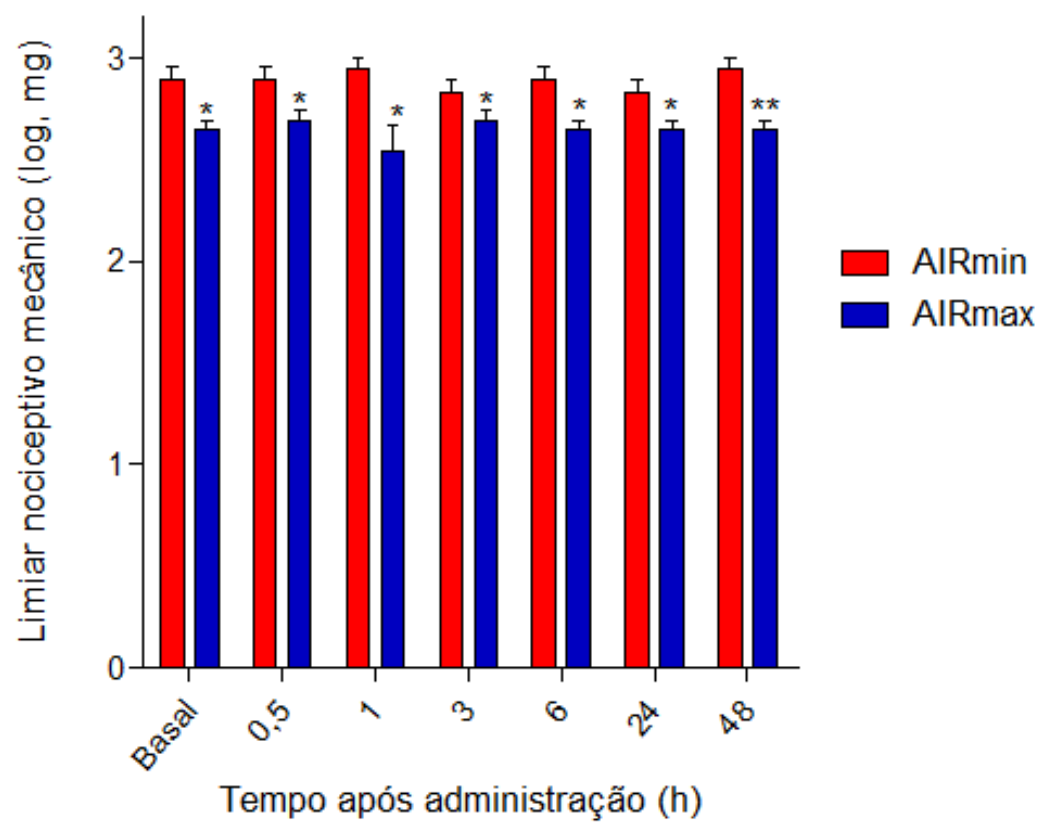

Figura 6 - Avaliação da nocicepção dos animais AIRmax e AIRmin após a administração de salina. Animais AIRmax e AIRmin ( $n=4)$ foram inoculados no coxim plantar com $30 \mu 1$ de solução salina apirogênica estéril e testados com os filamentos de von Frey.

* - AIRmin vs. AIRmax $(* p<0.05 ; * * p<0.01)$. Os resultados representam a média \pm e.p.m.
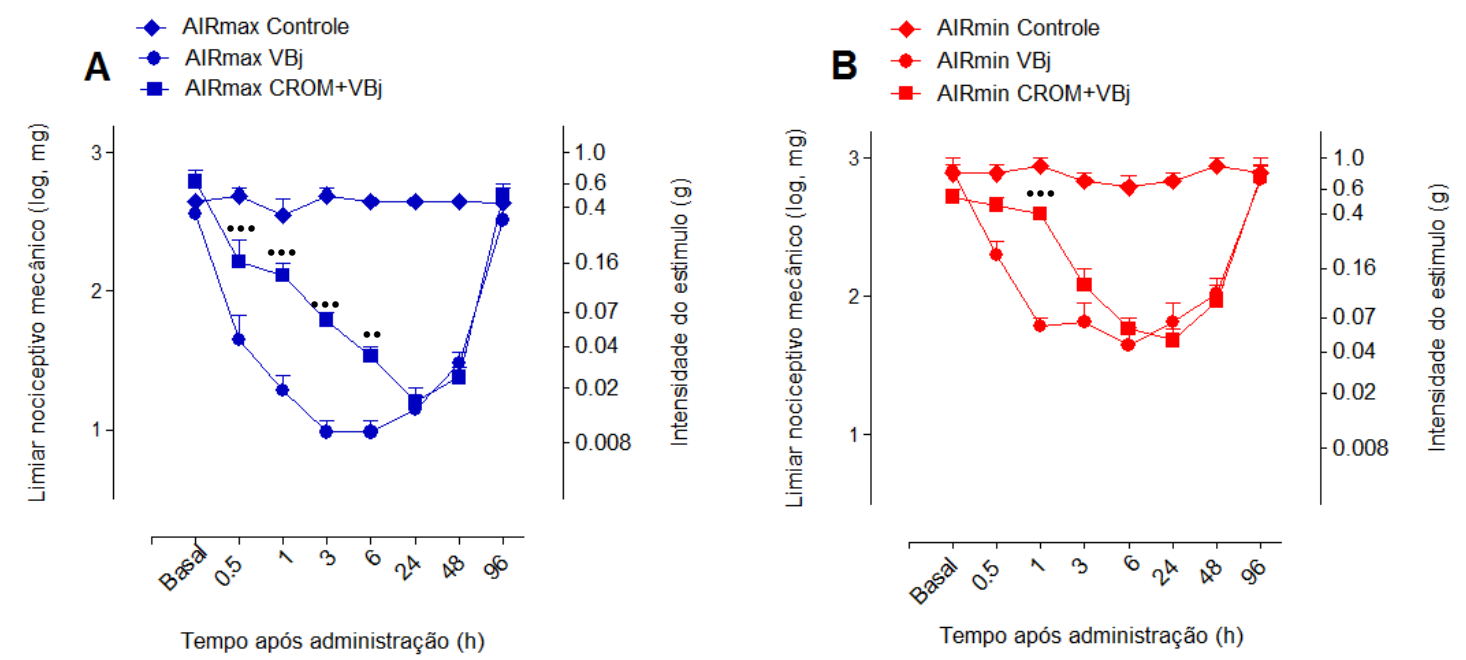

Figura 5 - Avaliação da nocicepção sob estímulo de VBj (fêmeas). Animais AIRmax (A) e AIRmin (B) (n=4), pré-tratados com $100 \mathrm{mg} / \mathrm{kg}$ de CROM, foram inoculados no coxim plantar com $1 \mu \mathrm{g}$ de $\mathrm{VBj} / \mathrm{pata}$ e testados com os filamentos de von Frey.

- - VBj vs. $\mathrm{CROM}+\operatorname{VBj}(\bullet \mathrm{p}<0.01 ; \cdots \mathrm{p}<0.001)$. Os resultados representam a média \pm e.p.m. 
- AIRmax Controle

$\diamond$ AlRmax CROM

- AIRmax VBj

- AIRmax CROM+VB

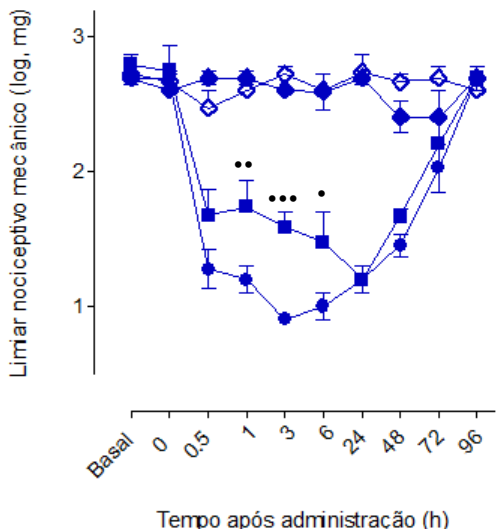

- AlRmin Controle

$\diamond$ AIRmin CROM

- AlRomin VBj

- AlRmin CROM+VB]
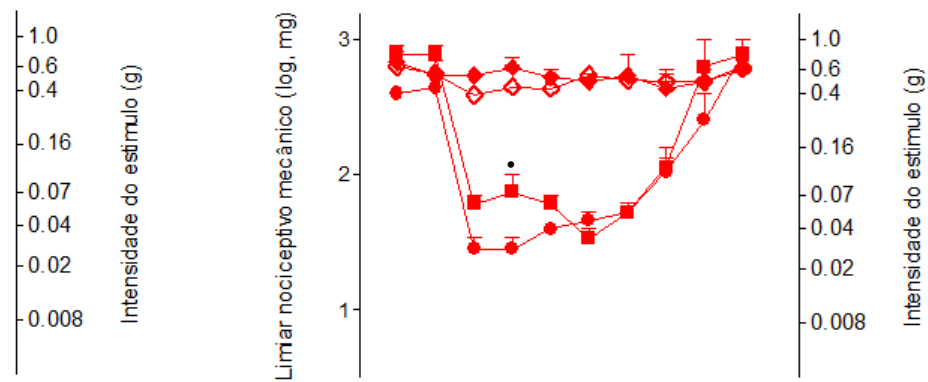

$8^{8^{80}} 00^{5} \times 32^{2} x^{8} 1^{2} 9^{6}$

Tempo após administração (h)

- BALB/c Controle

$\diamond$ BALB/C CROM

- BALB/c VBj

- $\mathrm{BALB} / \mathrm{C} \mathrm{CROM}+\mathrm{VBj}$

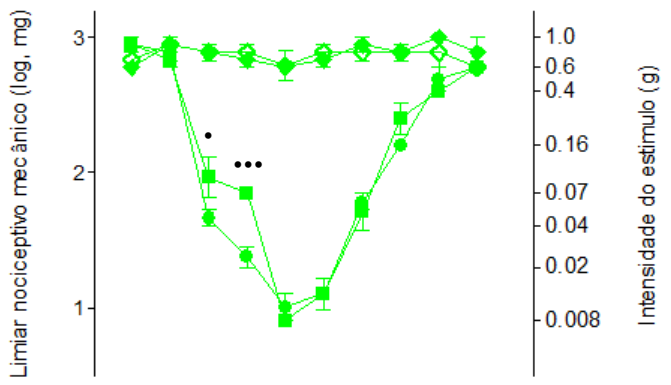

$00^{5} \times 362^{2} x^{8} 1^{2} 9^{6}$

Tempo após administração (h)

Figura 7 - Avaliação da nocicepção sob estímulo de VBj (machos). Camundongos AIRmax, AIRmin e $\mathrm{BALB} / \mathrm{c}(\mathrm{n}=4)$ pré-tratados com $100 \mathrm{mg} / \mathrm{kg}$ de $\mathrm{CROM}$, foram inoculados no coxim plantar com $1 \mu \mathrm{g}$ de $\mathrm{VBj} /$ pata e testados com os filamentos de von Frey.

- $\mathrm{VBj}$ vs. $\mathrm{CROM}+\operatorname{VBj}(\bullet p<0.05 ; \bullet p<<0.01 ; \cdots p<<0,001)$. Os resultados representam a média \pm e.p.m. 


\subsection{Avaliação da Ação Local do Cromoglicato de Sódio}

Para avaliar a capacidade do CROM em estabilizar os mastócitos dos animais AIRmax e AIRmin, foi feita uma análise histológica da desgranulação dos mastócitos mesentéricos. Os animais foram pré-tratados por 3 dias com CROM (100 mg/kg) e injetados i.p. com $1 \mu \mathrm{g} / \mathrm{g}$ do Composto 48/80, uma substância com potencial de desgranular os mastócitos, ou com $5 \mu \mathrm{g}$ do VBj. Após 30 minutos, o mesentério foi coletado.

A avaliação da atuação do CROM sobre a desgranulação dos mastócitos se deu através da quantificação e classificação dos mastócitos quanto a sua integridade morfológica, conforme ilustrado na Figura 8. A análise foi expressa como a proporção (\%) dos mastócitos desgranulados relativa ao número de mastócitos presentes no mesentério (MOTA, 1964) por $\mathrm{cm}^{2}$, sendo apresentada na Tabela 2 .

Animais de ambas as linhagens que não receberam nenhum tratamento possuem no mesentério cerca de $25 \%$ dos mastócitos desgranulados (dados não apresentados). A administração do veículo i.p. aumentou essa porcentagem em 10\% nos animais AIRmax e 25\% nos AIRmin (animais controle).

A administração do Composto 48/80 aumentou o número de mastócitos desgranulados em aproximadamente $10 \%$ em relação aos animais controle na linhagem AIRmax e $20 \%$ nos AIRmin. Nos animais pré-tratados com CROM, porém, houve uma inibição do aumento dessa desgranulação em ambas as linhagens de quase 100\% em AIRmax e de 85\% em AIRmin.

Da mesma forma, a injeção do $\mathrm{VBj}$ aumentou quase $15 \%$ do número de mastócitos desgranulados em relação ao controle nos animais AIRmax e cerca de $25 \%$ nos AIRmin. O prétratamento com CROM inibiu esse aumento em $80 \%$ em AIRmax e em cerca de $95 \%$ em AIRmin.

O experimento demonstrou que os mastócitos desgranulam em resposta ao Composto 48/80 e ao VBj, e que o pré-tratamento com CROM é capaz de inibir essa resposta a ambos os estímulos, de modo que o nível de desgranulação dos mastócitos seja semelhante ao nível de desgranulação nos animais controle, indicando a eficácia do tratamento com a droga em estabilizar os mastócitos. 


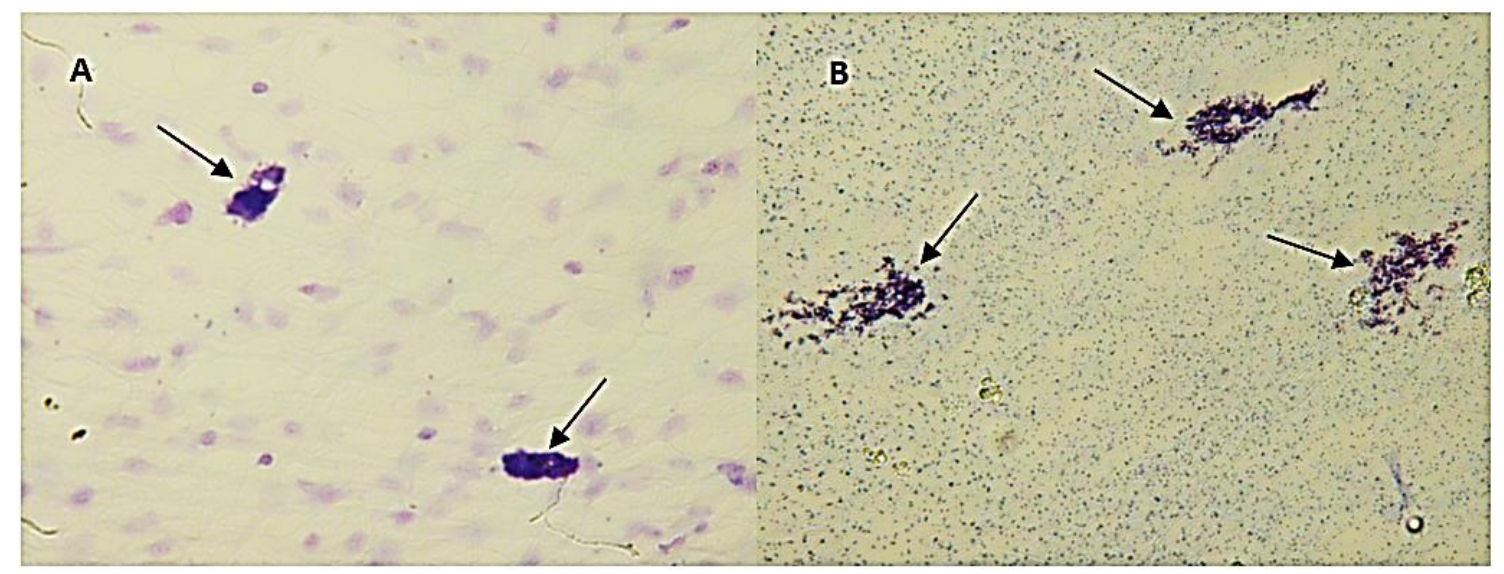

Figura 8 - Histologia de mastócitos mesentéricos. Mastócitos íntegros (A) e desgranulados (B) do mesentério dos camundongos, corados com azul de toluidina e fotografados em aumento de $20 \mathrm{x}$.

Tabela 4 - Porcentagem de desgranulação dos mastócitos mesentéricos

\begin{tabular}{cccccc}
\hline Controle & C 48/80 & $\begin{array}{c}\text { CROM } \\
+ \text { C48/80 }\end{array}$ & VBj & $\begin{array}{c}\text { CROM } \\
+ \text { VBj }\end{array}$ \\
\hline AlRmax & $35 \%$ & $47 \%$ & $36 \%$ & $48 \%$ & $44 \%$ \\
\hline AlRmin & $50 \%$ & $70 \%$ & $59 \%$ & $76 \%$ & $52 \%$ \\
\hline
\end{tabular}

Animais pré-tratados i.p. com PBS ou com CROM (100 mg/kg) por 3 dias consecutivos e injetados com o Composto 48/80 ou VBj no $4^{\circ}$ dia (n=3-8). Controle: animais que receberam apenas o veículo (PBS) i.p.

\subsection{Avaliação da Migração Celular}

A migração celular dos leucócitos ao peritônio sob estímulo do VBj foi avaliada por contagem total e diferencial das células e por citometria de fluxo.

\subsubsection{Contagem Total de Células}

As células coletadas do lavado peritoneal foram quantificadas em uma câmara hemocitométrica de Malassez para determinação do número de leucócitos. A coleta foi realizada 1, 3 e 24 hs após a inoculação i.p. do $\operatorname{VBj}(5 \mu \mathrm{g})$.

Os animais AIRmax apresentaram maior número de leucócitos do que os animais AIRmin 3 hs após a injeção do veneno. Não houve, porém, diferenças significativas entre os demais grupos de animais ou entre os mesmos grupos nos diferentes horários (Figura 9). 

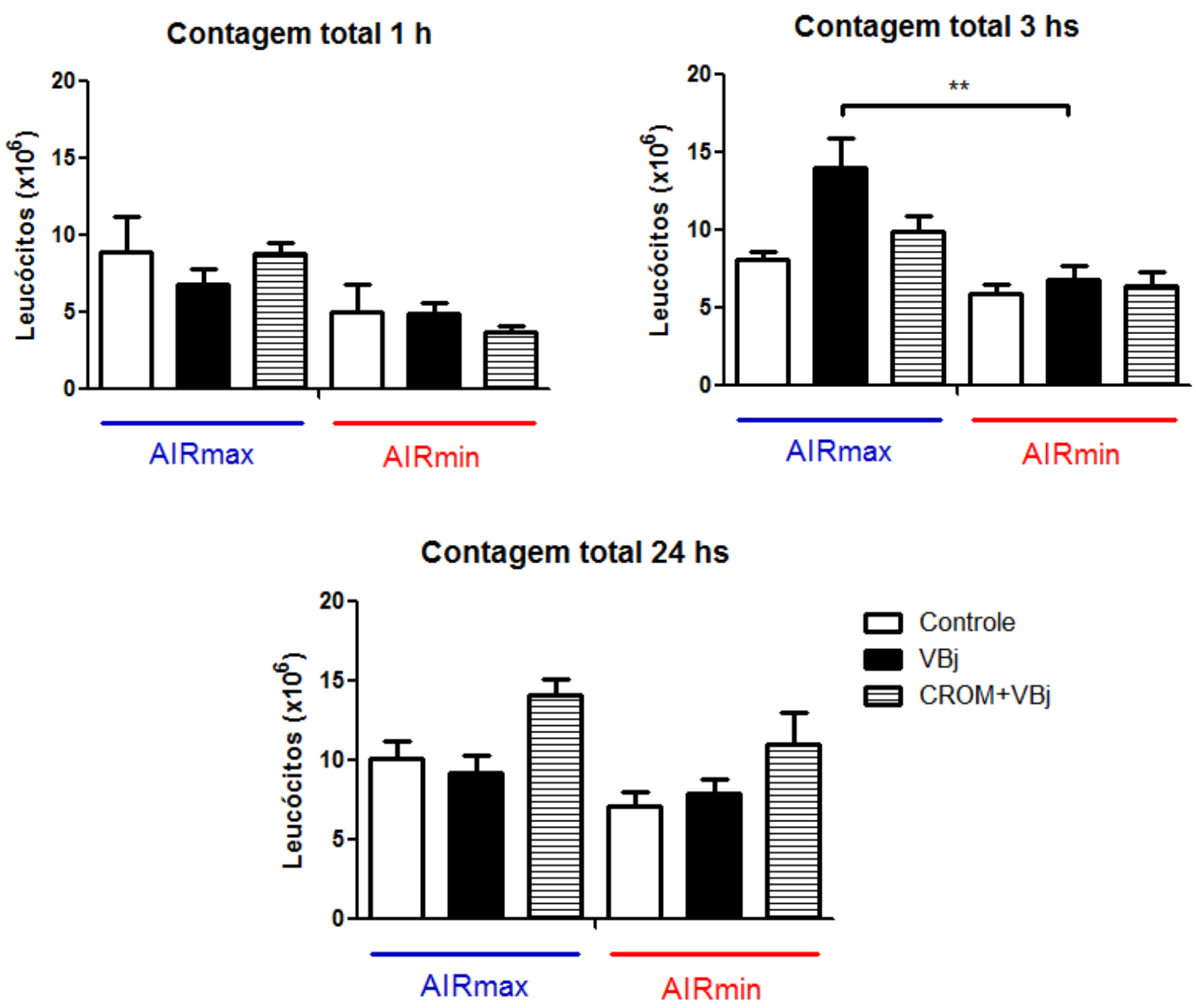

Figura 9 - Contagem total de células. Número de leucócitos peritoneais de animais de ambas as linhagens ( $\mathrm{n}=$ 5) após 1, 3 e 24 hs da injeção i.p. de $5 \mu \mathrm{g}$ de $\mathrm{VBj}$.

* - AIRmax vs. AIRmin (**p < 0.01). Os resultados representam a média \pm e.p.m. 


\subsubsection{Contagem Diferencial de Células}

As células coletadas após 1, 3 e 24 hs da injeção do veneno foram classificadas e quantificadas de acordo com suas características morfológicas (Figura 10).

O número de mastócitos e linfócitos do peritônio não apresentou diferenças significativas entre as linhagens e não foi afetado pelo tratamento.

O número de macrófagos dos animais tratados com CROM, no entanto, foi diferente entre as linhagens após $1 \mathrm{~h}$ da inoculação do veneno, sendo maior em AIRmax do que em AIRmin. Já às 3 hs, o número de macrófagos dos animais tratados com o veneno foi maior em AIRmax do que em AIRmin. Não houve diferença significativa entre os grupos da mesma linhagem nesses horários. Às 24 hs, o número de macrófagos dos animais tratados com CROM foi maior do que dos animais controle e dos tratados apenas com o veneno.

O número de neutrófilos apresentou diferenças apenas às 24 hs da injeção do veneno, sendo maior nos animais AIRmax tratados com o veneno do que nos AIRmin do mesmo grupo e nos animais controle na linhagem AIRmax (Figura 11).

As células foram também coradas com azul de toluidina para evidenciar os mastócitos, sendo classificadas e quantificadas de acordo com a sua integridade, conforme ilustrado na Figura 12.

A injeção i.p. do VBj aumentou o número de mastócitos desgranulados em ambas as linhagens à 1 e 3 hs, e às 24 hs apenas em AIRmax. O tratamento com CROM, no entanto, não alterou significativamente o número de mastócitos desgranulados em nenhum grupo (Tabela 3). 
Contagem diferencial - $1 \mathrm{~h}$

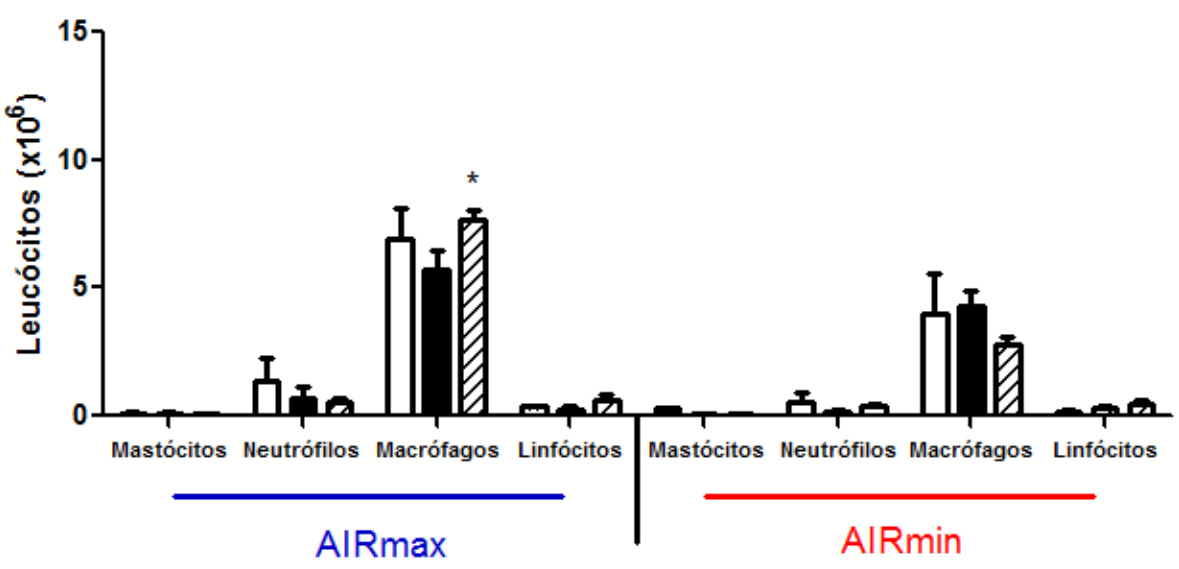

Contagem diferencial - 3 hs

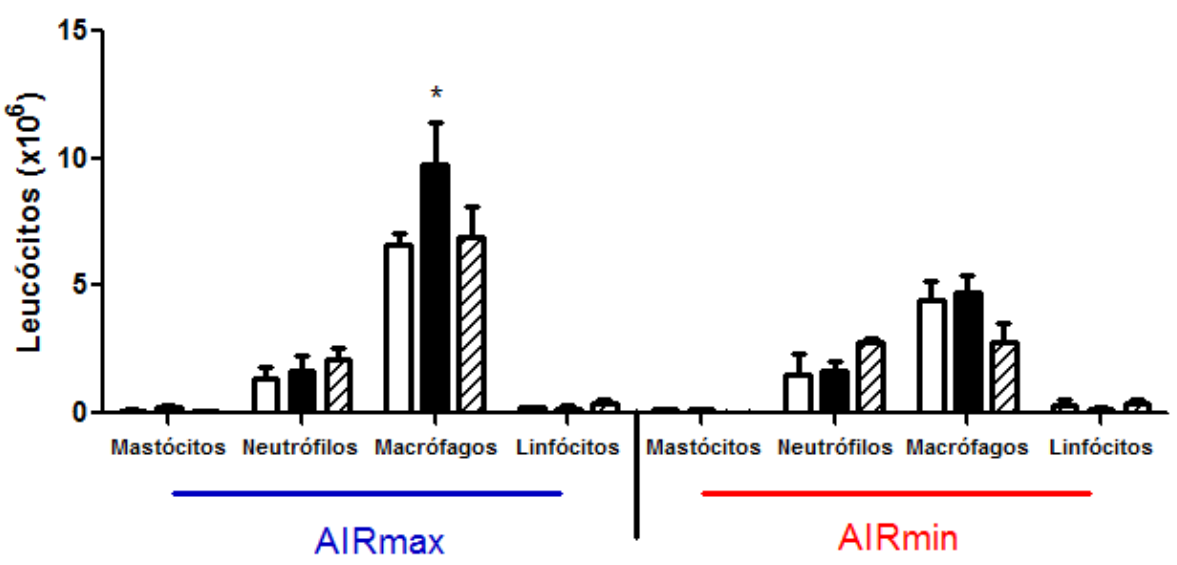

Contagem diferencial - 24 hs

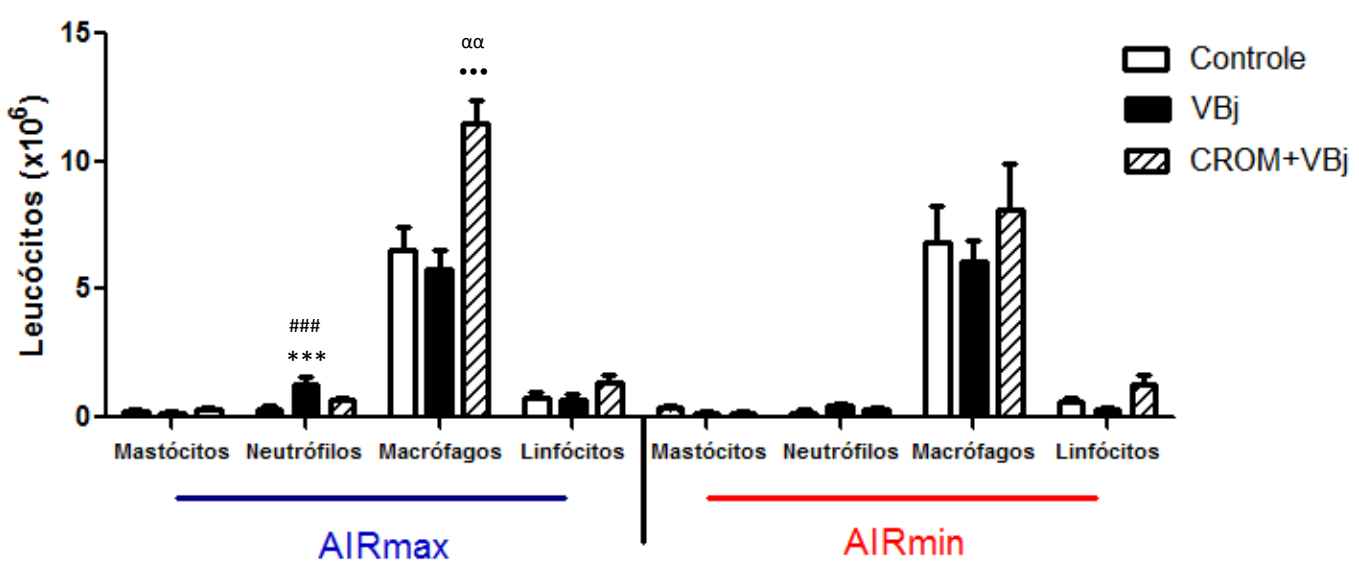

Figura 10 - Contagem diferencial de células. Número de mastócitos, neutrófilos, macrófagos e linfócitos peritoneais de animais de ambas as linhagens ( $\mathrm{n}=3$ ) após 1, 3 e 24 hs da injeção de $5 \mu \mathrm{g}$ de $\mathrm{VBj}$.

* - AIRmax vs. AIRmin $(* \mathrm{p}<0.5$; ***p < 0.001). \# - Controle vs. VBj (\#\#\# p <0 .001). $\alpha$ - Controle vs. $\mathrm{CROM}+\mathrm{VBj}(\alpha \alpha \mathrm{p}<0.01) . \bullet-\mathrm{VBj}$ vs. CROM+VBj $(\cdots \mathrm{p}<0.001)$. Os resultados representam a média \pm e.p.m. 
Neutrófilos 24 hs

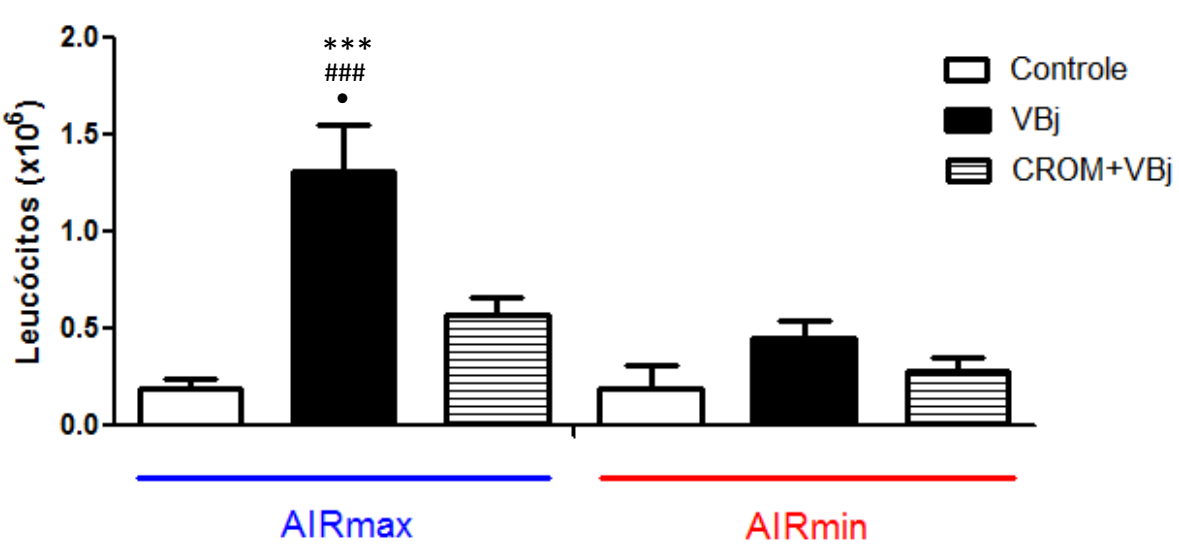

Figura 11 - Contagem de neutrófilos. Número de neutrófilos peritoneais de animais de ambas as linhagens (n=3) após 24 hs da injeção i.p. de $5 \mu \mathrm{g}$ de VBj.

* - AIRmax vs. AIRmin (***p < 0.001). \# Controle vs. VBj (\#\#\# p < 0.001$)$. - VBj vs. CROM+VBj $(\bullet p<0.01)$. Os resultados representam a média \pm e.p.m.

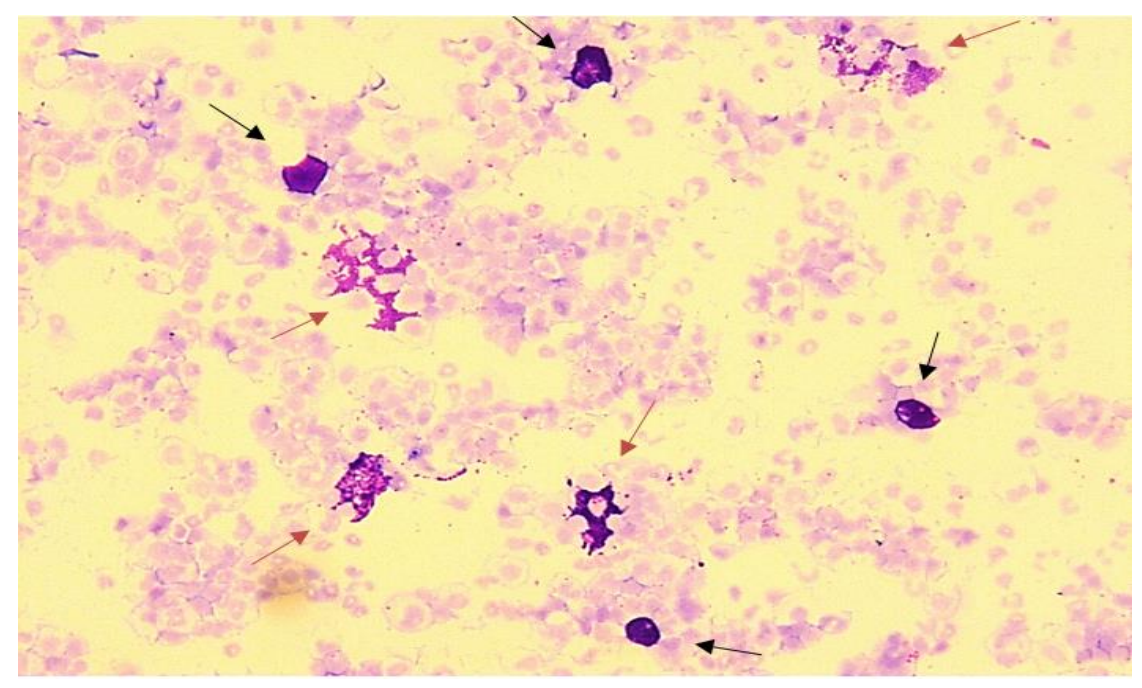

Figura 12 - Microscopia de mastócitos peritoneais corados com azul de toluidina. Células peritoneais coradas com o corante azul de toluidina para evidenciar mastócitos. Mastócitos íntegros (setas pretas) e desgranulados (setas vermelhas). Resolução 10 x. 
Tabela 5 - Efeito do tratamento do CROM sob a desgranulação dos mastócitos peritoneais após a injeção do veneno

\begin{tabular}{lcccc}
\hline & & PBS & PBS+VBj & CROM+VBj \\
\hline AIRmax & $1 h$ & $30 \%$ & $75 \%$ & $93 \%$ \\
\cline { 2 - 5 } & $3 h s$ & $70 \%$ & $84 \%$ & $81 \%$ \\
\cline { 2 - 5 } AIRmin & $24 h s$ & $70 \%$ & $91 \%$ & $78 \%$ \\
& $1 h$ & $58 \%$ & $88 \%$ & $86 \%$ \\
& $3 h s$ & $46 \%$ & $95 \%$ & $78 \%$ \\
\cline { 2 - 5 } & $24 h s$ & $73 \%$ & $42 \%$ & $86 \%$ \\
\hline
\end{tabular}

Porcentagem de mastócitos peritoneais desgranulados em animais pré-tratados com $100 \mathrm{mg} / \mathrm{kg}$ de CROM ou PBS e injetados com $5 \mu \mathrm{g}$ de $\mathrm{VBj}$ ou PBS (n=3). 


\subsubsection{Avaliação das subpopulações de células no peritônio após a inoculação do veneno}

Para analisar o perfil de células presentes no peritônio após a inoculação do veneno, foi realizado um ensaio para identificar o fenótipo das células coletadas 3 e 24 hs após a inoculação i.p. do veneno. As células foram marcadas com anticorpos monoclonais específicos para CD3, CD11b, CD19, cKIT, F4/80, FcєRI, GR-1 e MHC-II, e estas marcações foram avaliadas no citômetro de fluxo.

Primeiramente, foi analisada a população $\mathrm{Fc}_{\mathrm{R}} \mathrm{RI}^{+} / \mathrm{CKIT}^{+}$, correspondente aos mastócitos (Figura 13). A injeção de VBj levou à diminuição dessa população em ambas as linhagens após 3 e 24 hs da inoculação. O pré-tratamento com CROM, no entanto, inibiu parcialmente essa diminuição de células nos animais AIRmax após 3 hs do veneno (Figura 14). Este resultado indica que a diminuição observada é devido a desgranulação induzida pelo veneno que foi parcialmente inibida pelo tratamento com CROM.

A seguir, foram analisadas as populações de células marcadas para CD3 e CD19, sendo o fenótipo $\mathrm{CD}^{+} / \mathrm{CD} 19^{-}$correspondente aos linfócitos $\mathrm{T}$ e o fenótipo $\mathrm{CD} 3{ }^{-} / \mathrm{CD} 19^{+}$, aos linfócitos B. Não houve diferenças significativas entre as linhagens ou entre os grupos de tratamento dessas populações (dados não apresentados).

A partir da população $\mathrm{CD}^{-} 9^{-}$, foram analisadas as populações $\mathrm{CD}_{11 \mathrm{~b}^{+} / \mathrm{F} 4 / 80^{-} / \mathrm{GR}-}$ $1^{\text {high }} / \mathrm{MHC}^{-\mathrm{II}^{-}}$, correspondente aos neutrófilos, e CD11b $\mathrm{b}^{+} / \mathrm{F} 4 / 80^{+} / \mathrm{GR}-1^{\text {low }} / \mathrm{MHC}-\mathrm{II}^{+}$, correspondente aos macrófagos (Figura 15). Foram observadas diferenças nessas populações somente após 24 hs do veneno. O número de macrófagos dos animais AIRmax aumentou na presença do veneno, sendo esse aumento maior do que nos animais AIRmin. O aumento dessa população foi inibido na presença de CROM. Apesar de não haver diferenças significativas no número de neutrófilos, o perfil parece ser semelhante (Figura 16). 


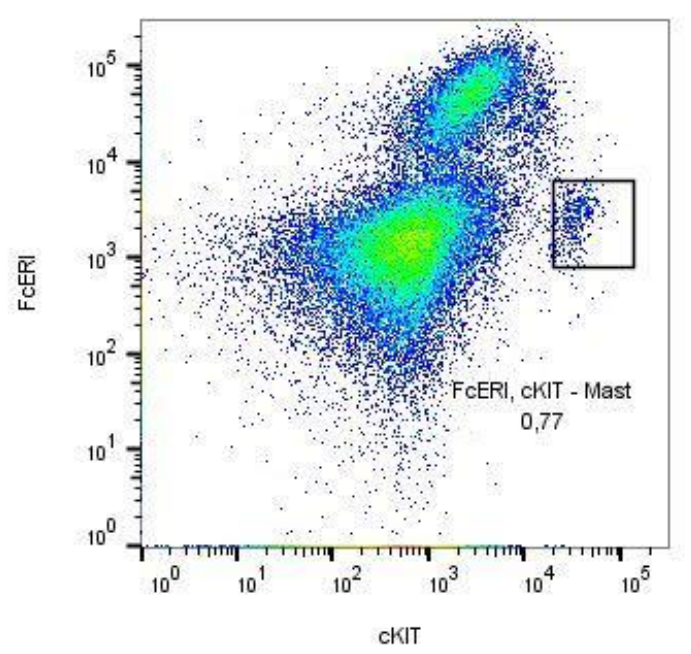

Figura 13 - Citograma representativo das populações de células do peritônio marcadas para FceRI e cKIT.

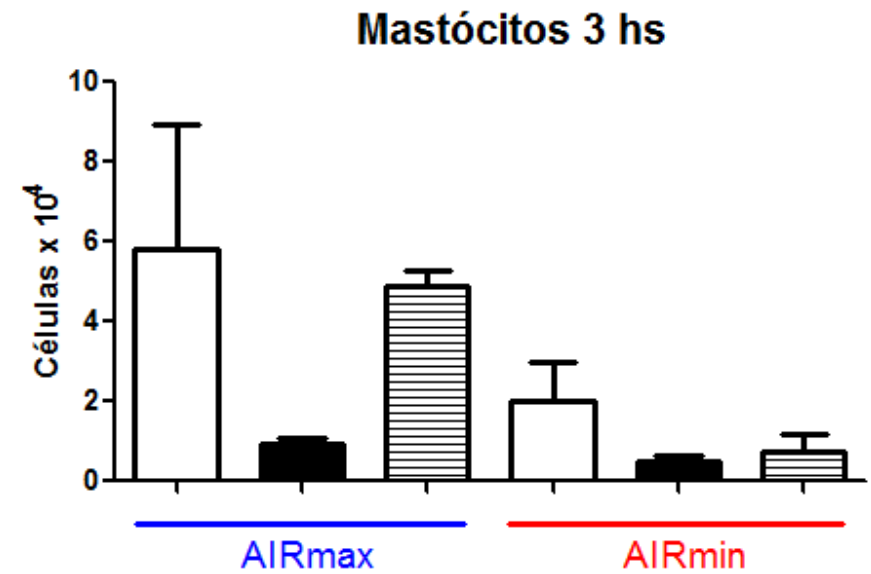

Mastócitos 24 hs

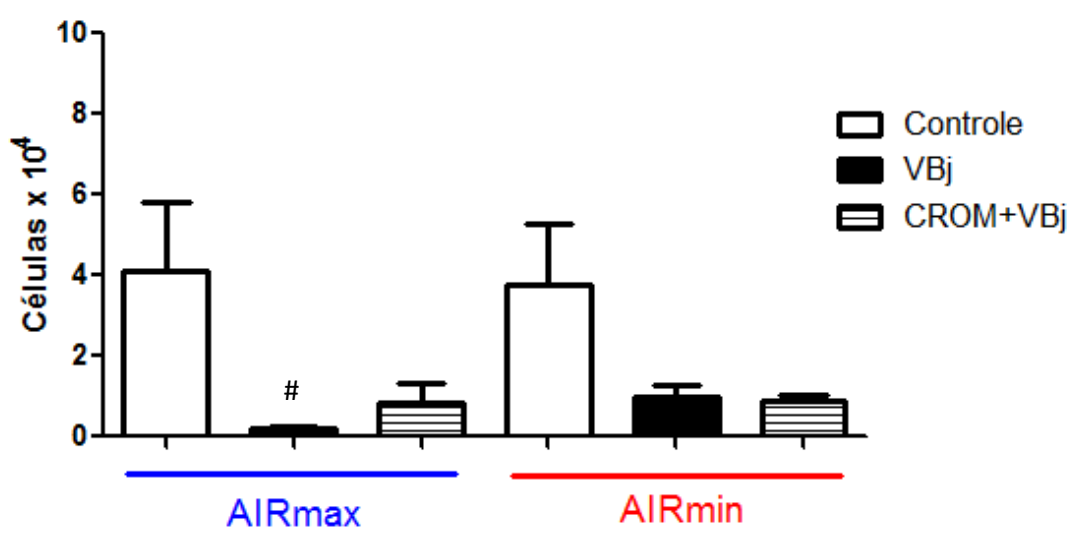

Figura 14 - Número absoluto de células peritoneais com o fenótipo Fc\&RI ${ }^{+} / \mathbf{c K I T}^{+}$. Células de animais de ambas as linhagens $(\mathrm{n}=3)$ pré-tratados com $100 \mathrm{mg} / \mathrm{kg}$ de CROM, coletadas 3 e 24 hs após a injeção i.p. de VBj, foram marcadas com anticorpos específicos para FceRI e cKIT e quantificadas por FACS.

\# Controle vs. VBj (\# p < 0.05). Os resultados representam a média \pm e.p.m. 

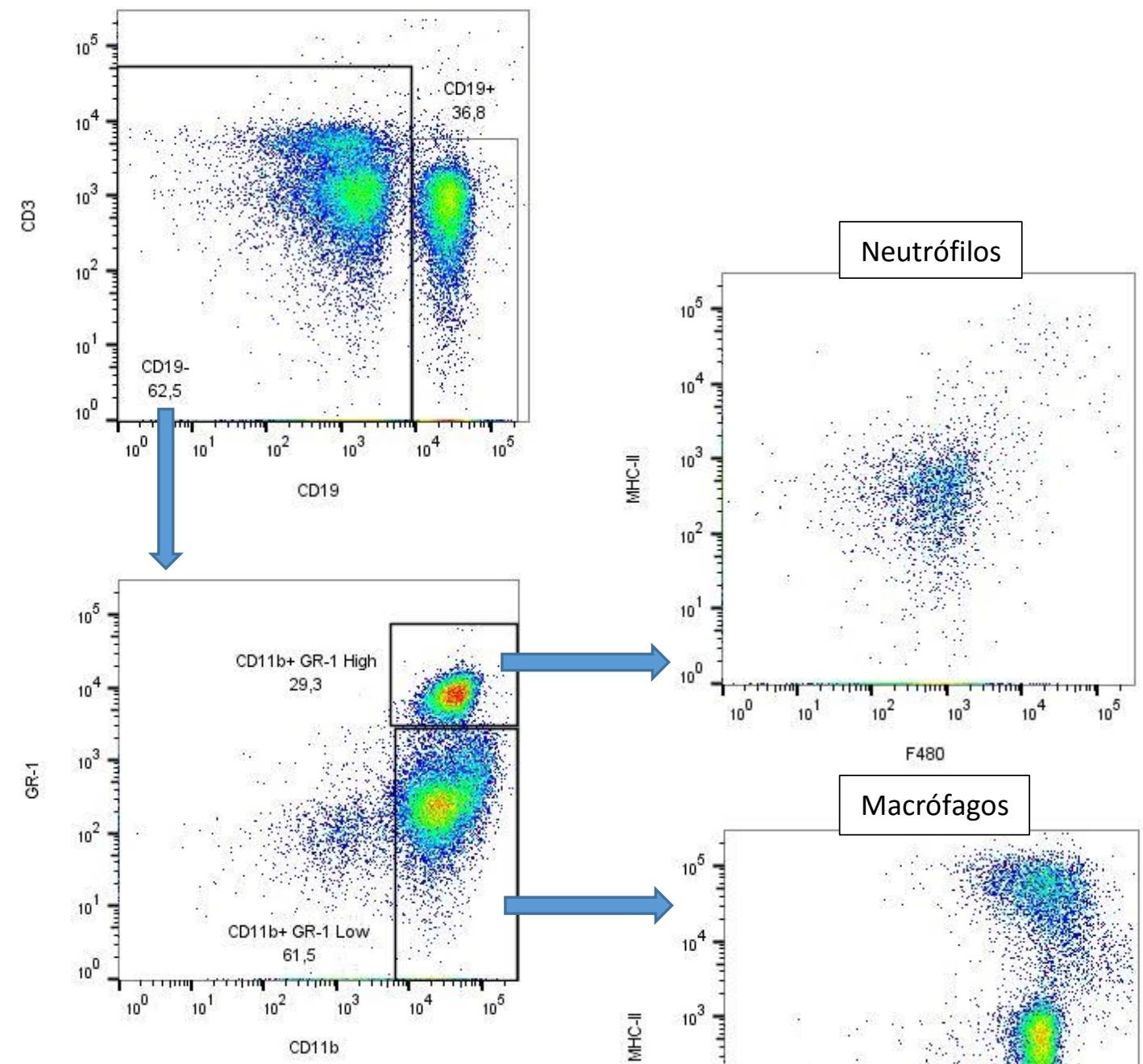


\section{Macrófagos 24 hs}

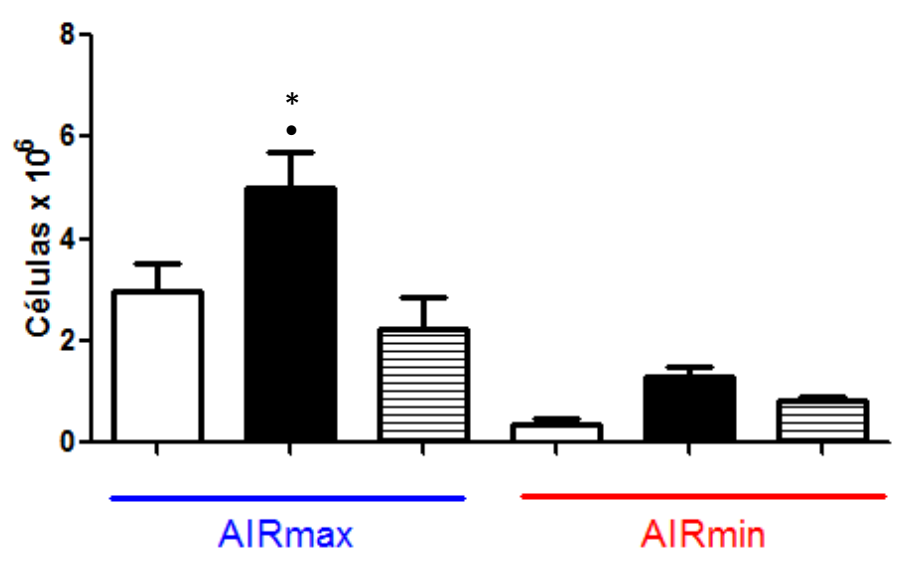

Neutrófilos 24 hs

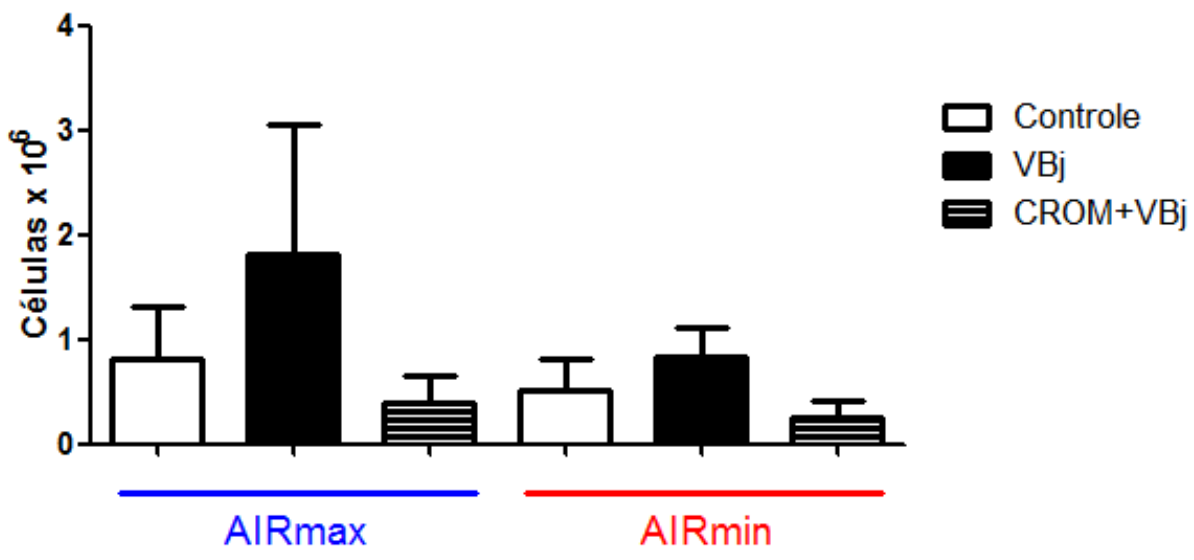

Figura 16 - Número absoluto de células peritoneais com os fenótipos CD11b ${ }^{+}$F4/80 /GR-1 high/MHCII $^{-}$(macrófagos) e CD11b $/$F4/80 $/$GR-1 ${ }^{\text {low }} / \mathbf{M H C}-$ II $^{+}$(neutrófilos). Células de animais de ambas as linhagens (n=3) pré-tratados com $100 \mathrm{mg} / \mathrm{kg}$ de CROM, coletadas 3 e 24 hs após a injeção i.p. de VBj foram marcadas com anticorpos específicos para CD11b, GR-1, F4/80 e MHC-II, e quantificadas por FACS.

*-AIRmax vs. AIRmin $(* \mathrm{p}<0.05)$. $\bullet \operatorname{VBj}$ vs. CROM+VBj $(\bullet \mathrm{p}<0.05)$. Os resultados representam a média \pm e.p.m. 


\subsection{Avaliação da Ativação Celular}

A ativação celular foi avaliada pela quantificação da produção de ROS através de ensaio de quimiluminescência dependente de luminol em células do lavado peritoneal estimuladas com PMA. Os resultados foram obtidos como unidades relativas de luz (URL) e a análise foi expressa por área sob a curva.

Para avaliar os efeitos mais imediatos dos mastócitos na ativação dos fagócitos produtores de ROS, foi realizada a quantificação das espécies reativas após 3 hs da injeção do VBj. Não houve diferença significativa entre os grupos de tratamento ou entre as linhagens (Figura 17).

Após 24 hs da injeção do VBj, no entanto, houve um aumento da produção de ROS pelos fagócitos em ambas as linhagens, sendo essa produção maior em AIRmax do que em AIRmin. O pré-tratamento com CROM $(100 \mathrm{mg} / \mathrm{kg})$ inibiu essa produção nos animais AIRmax (Figura 18). 


\section{Produção de ROS 3 hs}

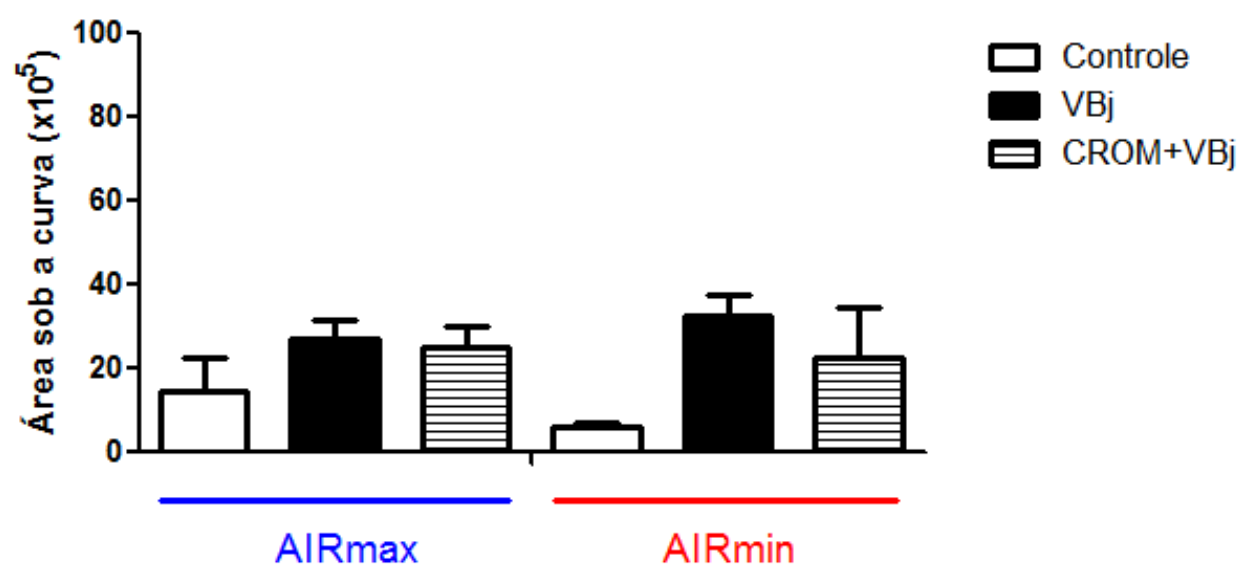

Figura 17 - Produção de ROS induzida pelo VBj após 3 hs. Quantificação da produção de ROS sob estímulo de PMA por células peritoneais de animais de ambas as linhagens ( $\mathrm{n}=2-6)$ pré-tratados com $100 \mathrm{mg} / \mathrm{kg}$ de CROM, coletadas 3 hs após a inoculação i.p. de VBj. Os resultados representam a média \pm e.p.m.

\section{Produção de ROS 24 hs}

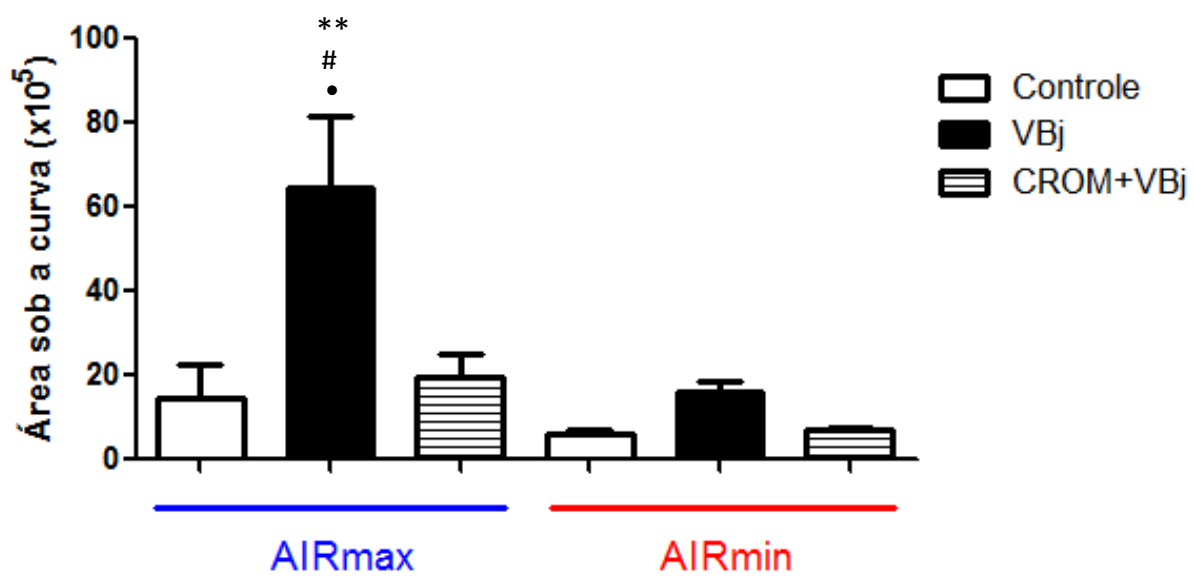

Figura 18 - Produção de ROS induzida por VBj após 24 hs. Quantificação da produção de ROS sob estímulo

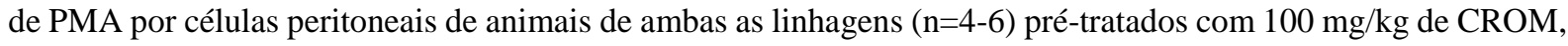
coletadas 24 hs após a inoculação i.p. de VBj.

* - AIRmax vs. AIRmin (** p <0.005) \# - Controle vs. VBj (\# p < 0.5). • - VBj vs. CROM+VBj $(\bullet p<0.5)$. Os resultados representam a média \pm e.p.m. 


\subsection{Avaliação da Produção de Citocinas}

Para avaliar a liberação de citocinas na cavidade peritoneal após a inoculação do VBj, foi realizado um ensaio imunoenzimático (ELISA) com anticorpos específicos para as citocinas IL-1 $\beta$, IL-6, IL-10 e TNF- $\alpha$ no sobrenadante de células peritoneais.

A análise da liberação de IL-1 $\beta$ após 3 hs da injeção do veneno não revelou diferenças significativas. A tendência do gráfico parece indicar que o veneno diminuiu essa liberação em ambas as linhagens e que o CROM modulou essa diminuição nos animais AIRmax. Após 24 hs do veneno, houve uma diminuição da liberação da citocina comparado às 3 hs e o prétratamento com CROM inibiu essa liberação nos animais AIRmin (Figura 19).

A liberação da citocina IL-6 somente foi detectada 3 hs após a injeção do veneno. Não houve diferenças estatísticas entre as linhagens ou entre os grupos de tratamento (Figura 20).

A citocina IL-10 também não apresentou diferenças estatísticas entre as linhagens ou entre os grupos de tratamento 3 ou 24 hs após a injeção de VBj (Figura 21).

A liberação de TNF- $\alpha$ não foi detectada em nenhum dos horários ou grupos de tratamento. 


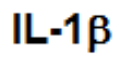

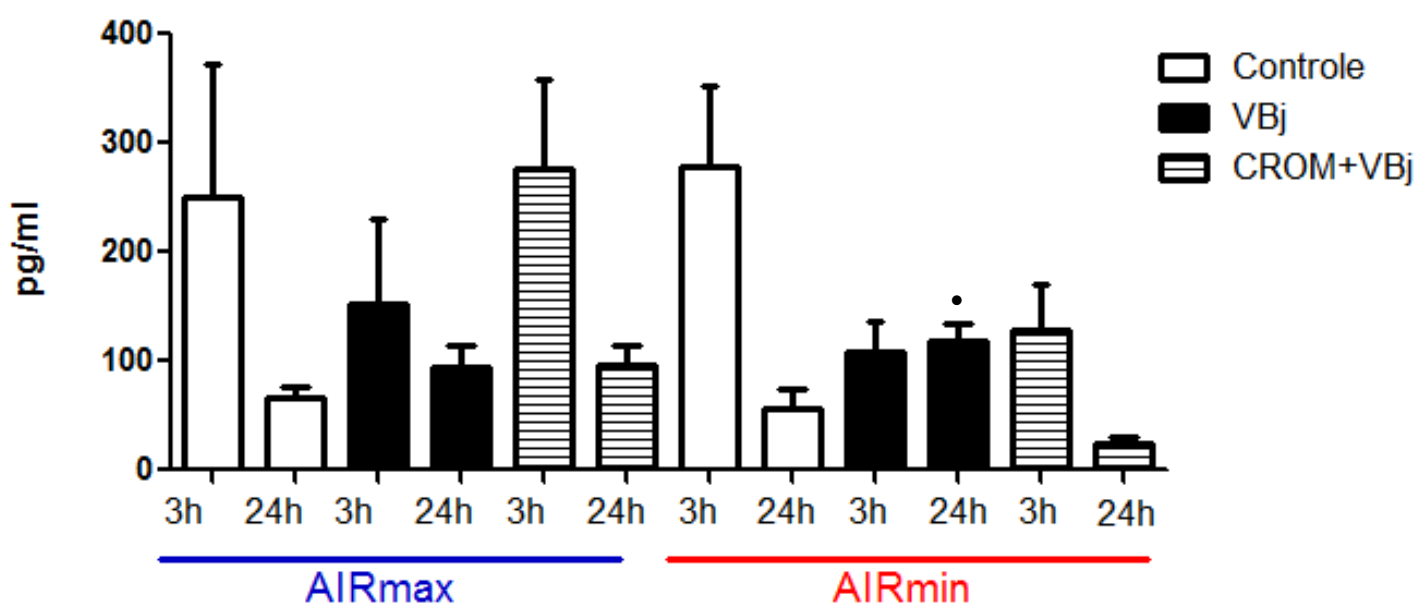

Figura 19 - Liberação de IL-1 $\beta$ induzida pelo veneno. Dosagem da liberação de IL-1 $\beta$ no sobrenadante de células peritoneais de animais de ambas as linhagens ( $\mathrm{n}=3)$, pré-tratados com $100 \mathrm{mg} / \mathrm{kg}$ de CROM, coletadas 3 e 24 hs após a inoculação i.p. de VBj.

- - VBj vs. CROM+VBj $(\bullet p<0.05)$. Os resultados expressam média \pm e.p.m.

IL-6

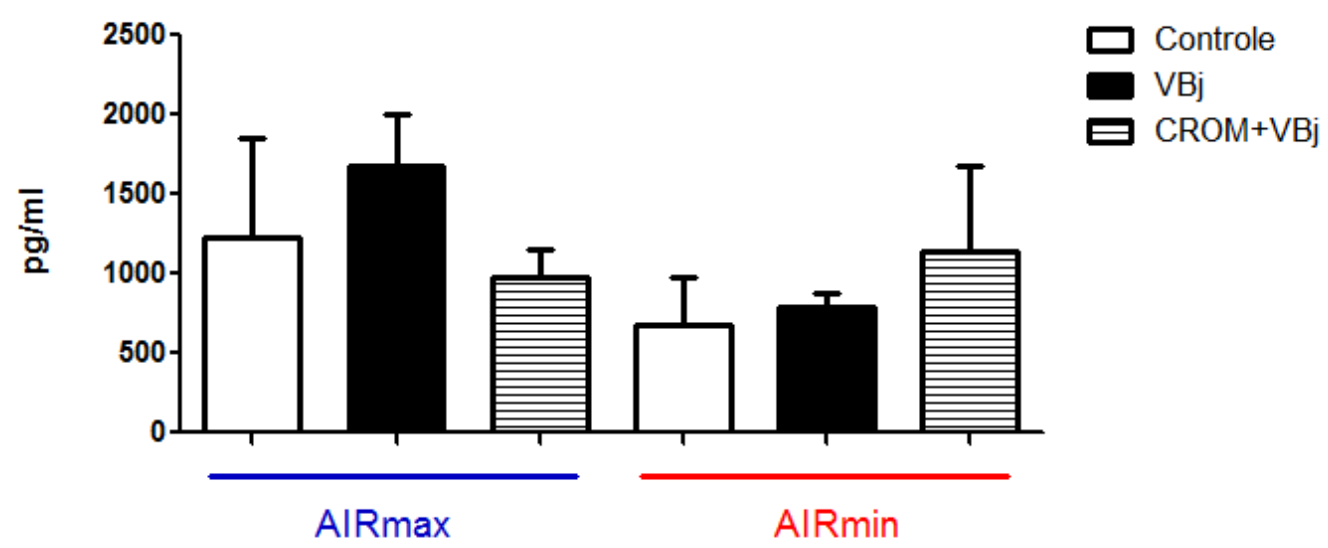

Figura 20 - Liberação de IL-6 induzida pelo veneno. Dosagem da liberação de IL-6 no sobrenadante de células peritoneais de animais de ambas as linhagens (n=3), pré-tratados com 100 mgkg de CROM, coletadas 3 hs após a inoculação i.p. de VBj. Os resultados expressam média \pm e.p.m. 


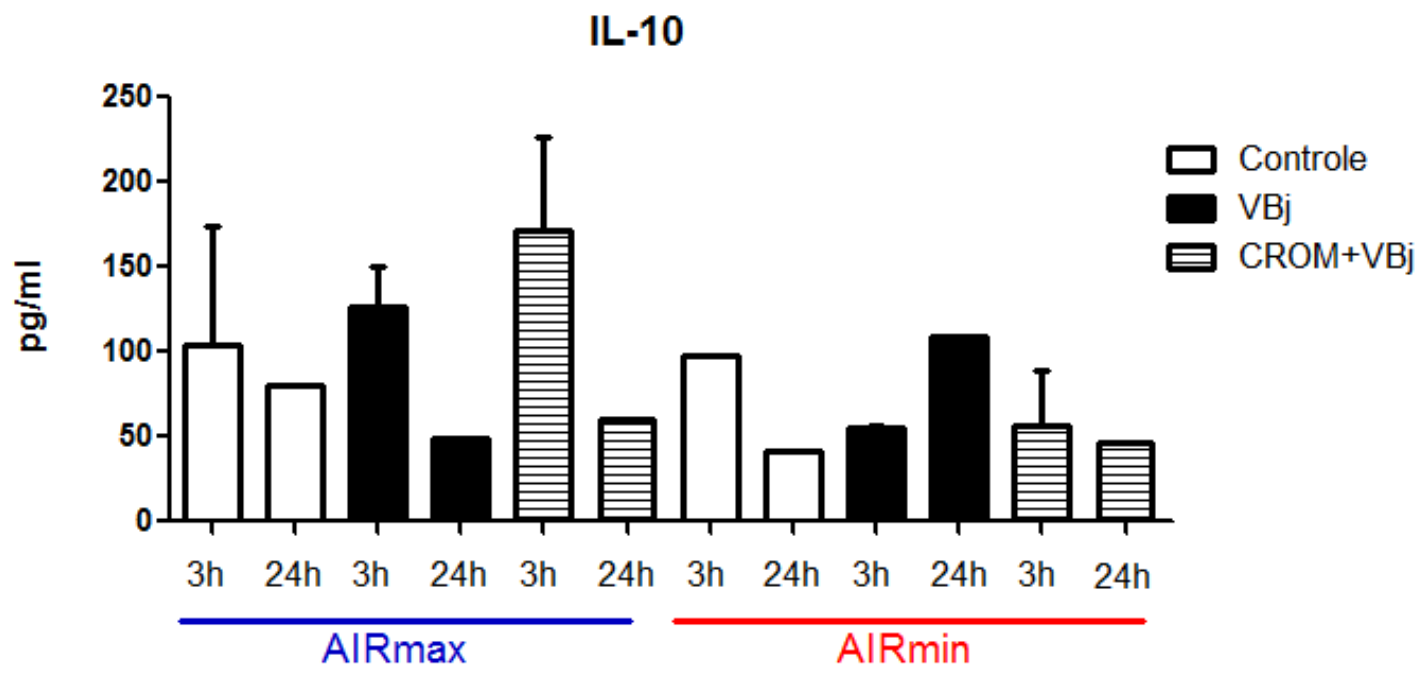

Figura 21 - Liberação de IL-10 induzida pelo veneno. Dosagem da liberação de IL-10 no sobrenadante de células peritoneais de animais de ambas as linhagens ( $\mathrm{n}=3$ ), pré-tratados com $100 \mathrm{mg} / \mathrm{kg}$ de CROM, coletadas 3 e 24 hs após a inoculação i.p. de VBj. Os resultados expressam média \pm e.p.m 


\subsection{Análise de Citocinas e Quimiocinas por Expressão Gênica}

A fim de analisarmos a expressão gênica das citocinas IL-1 $\beta$, IL-6, IL-10 e TNF- $\alpha$, e das quimiocinas CCL2 e CXCL2, realizamos RT-PCR em amostras de cDNA sintetizadas a partir do RNA extraído de células peritoneais após 3 e 24 hs da injeção do VBj.

A expressão dos genes estudados foi estimada por meio do método comparativo do cT através da análise da expressão relativa, usando-se como calibrador a média dos animais AIRmin controle 24 hs.

A análise da expressão de IL-1 $\beta$ indicou que há uma maior expressão da citocina nos animais AIRmax 3 hs após a injeção de PBS do que às 24 hs, bem como nos animais AIRmin pré-tratados com CROM 3 hs após o VBj em relação às 24 hs e em relação aos animais AIRmax (Figura 22A).

A análise da IL-6 revelou que os animais controle de ambas as linhagens apresentam maior expressão relativa da citocina às 3 hs do que às 24 hs e do que os animais tratados com o veneno e pré-tratados com CROM do mesmo horário (Figura 22B).

Já a análise da citocina TNF-a mostrou diferença significativa apenas no grupo de animais controle de ambas as linhagens, apresentando uma expressão maior da citocina 3 hs após a injeção do PBS em relação às 24 hs (Figura 23A).

A citocina anti-inflamatória IL-10 não teve diferença de expressão entre nenhum grupo de tratamento, linhagens ou tempo de inoculação do veneno (Figura 23A).

Uma vez que os mastócitos estão relacionados com o recrutamento de leucócitos, avaliamos também a expressão das quimiocinas CCL2 e CXCL2.

A análise da expressão relativa de CCL2 e CXCL2 revelou que os animais controle de ambas as linhagens expressam mais a quimiocinas às 3 hs do que às 24 hs. Nos animais AIRmin, ainda foi observado que o grupo controle também expressa mais CCL2 do que os grupos tratados com veneno ou com CROM às 24 hs (Figura 24). 

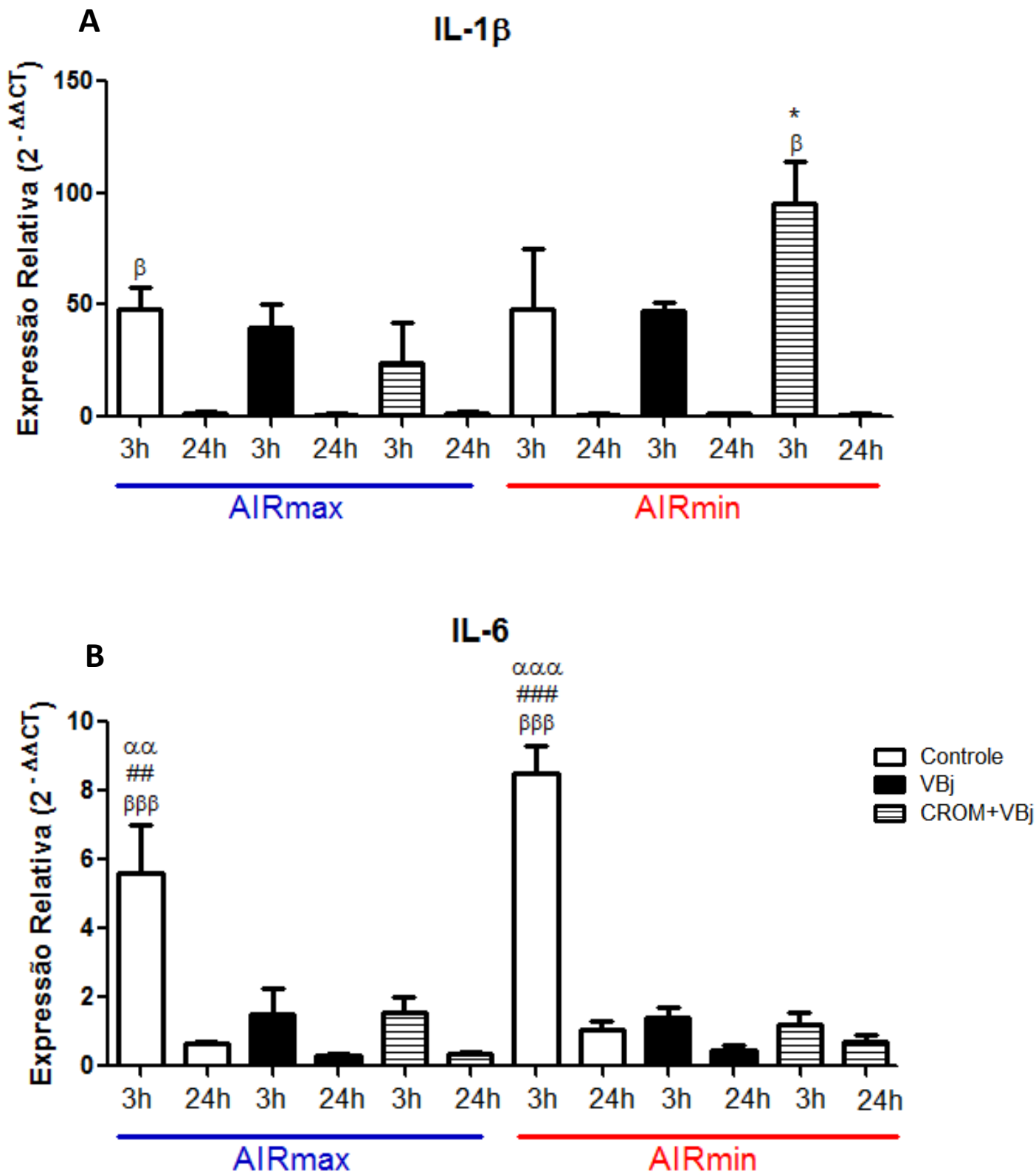

Figura 22 - Expressão relativa das citocinas IL-1ß e IL-6. Quantificação da expressão relativa de IL-1 $\beta$ (A) e IL-6 (B) em células peritoneais de animais de ambas as linhagens ( $\mathrm{n}=3$ ), pré-tratados com $100 \mathrm{mg} / \mathrm{kg}$ de CROM, coletadas 3 e 24 hs após a inoculação i.p. de VBj.

$\beta-3$ hs vs. 24 hs $(\beta \mathrm{p}<0.05 ; \beta \beta \beta \mathrm{p}<0,0001)$. * - AIRmax vs. AIRmin $(* \mathrm{p}<0.05)$. $\alpha$-Controle vs. CROM+VBj $(\alpha \alpha \mathrm{p}<0.001 ; \alpha \alpha \alpha \mathrm{p}<0.0001)$. \# - Controle vs. VBj (\#\# p < 0.001; \#\# $\mathrm{p}<0.0001)$. Os resultados expressam média \pm e.p.m 
TNF- $\alpha$

A

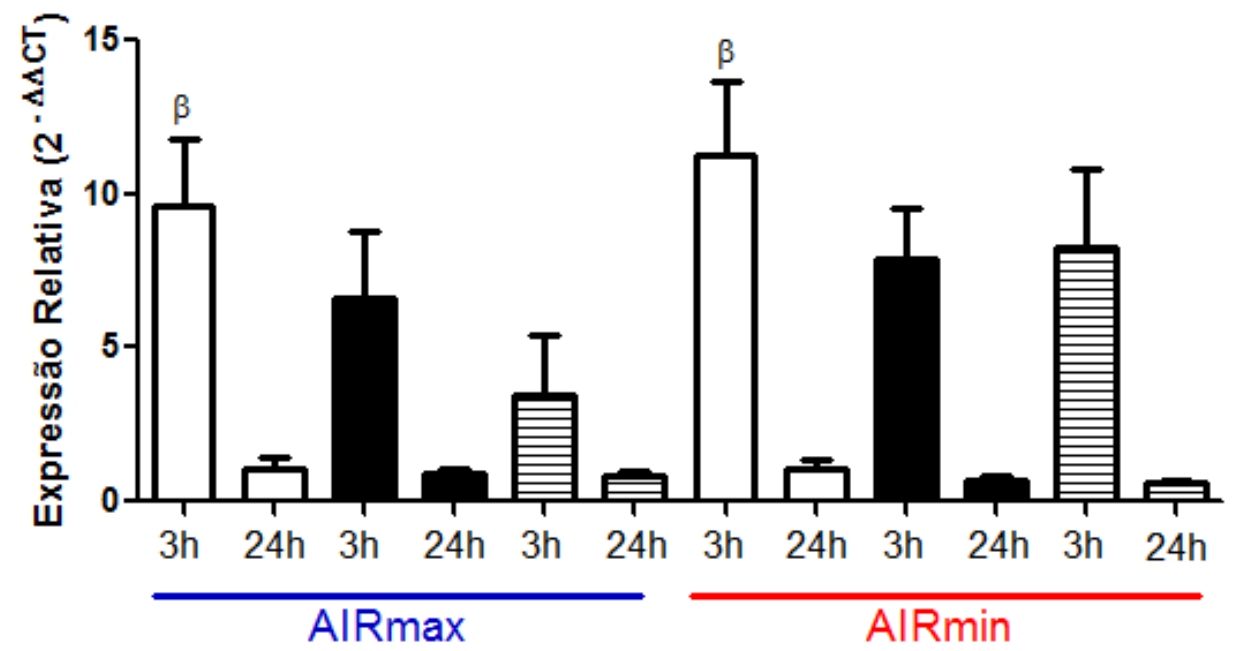

IL-10

B
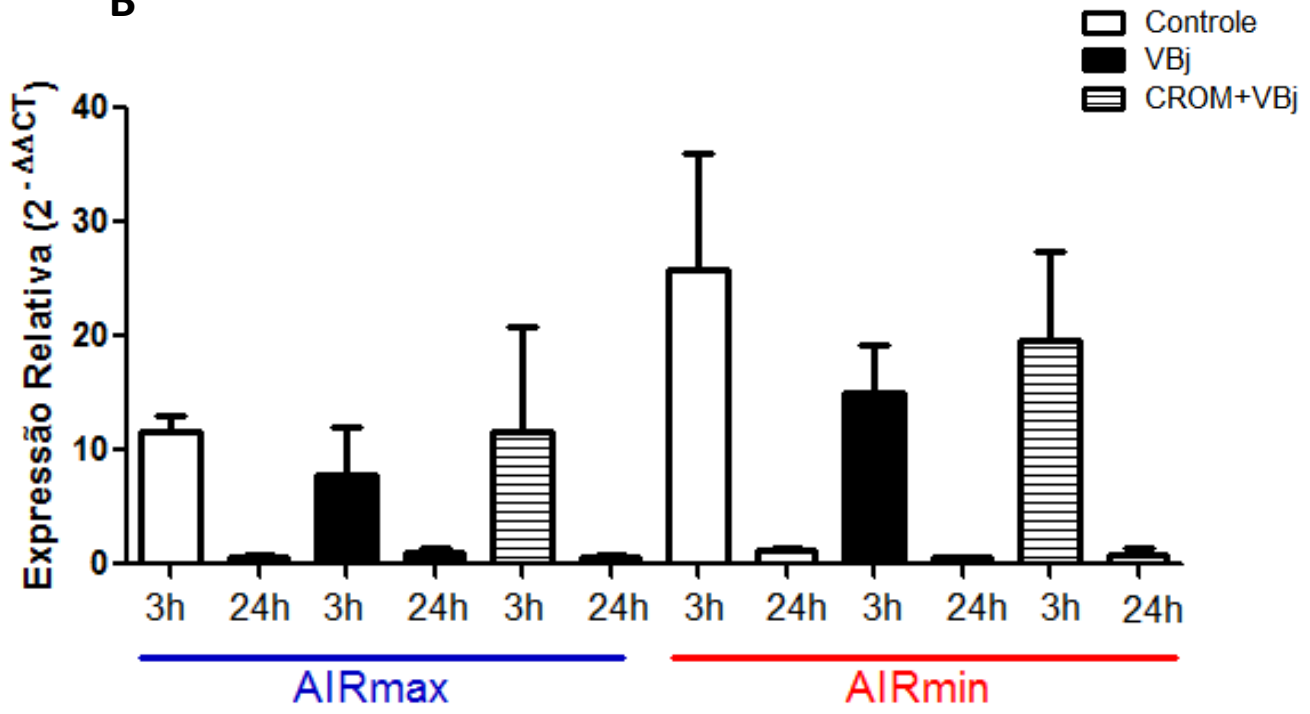

Figura 23 - Expressão relativa das citocinas de TNF- $\alpha$ IL-10. Quantificação da expressão relativa de TNF- $\alpha$ (A) e IL-10 (B) em células peritoneais de animais de ambas as linhagens ( $\mathrm{n}=3$ ), pré-tratados com $100 \mathrm{mg} / \mathrm{kg}$ de CROM, coletadas 3 e 24 hs após a inoculação i.p. de VBj.

$\beta-3$ hs vs. 24 hs $(\beta \mathrm{p}<0.05)$. Os resultados expressam média \pm e.p.m 


\section{CCL2}

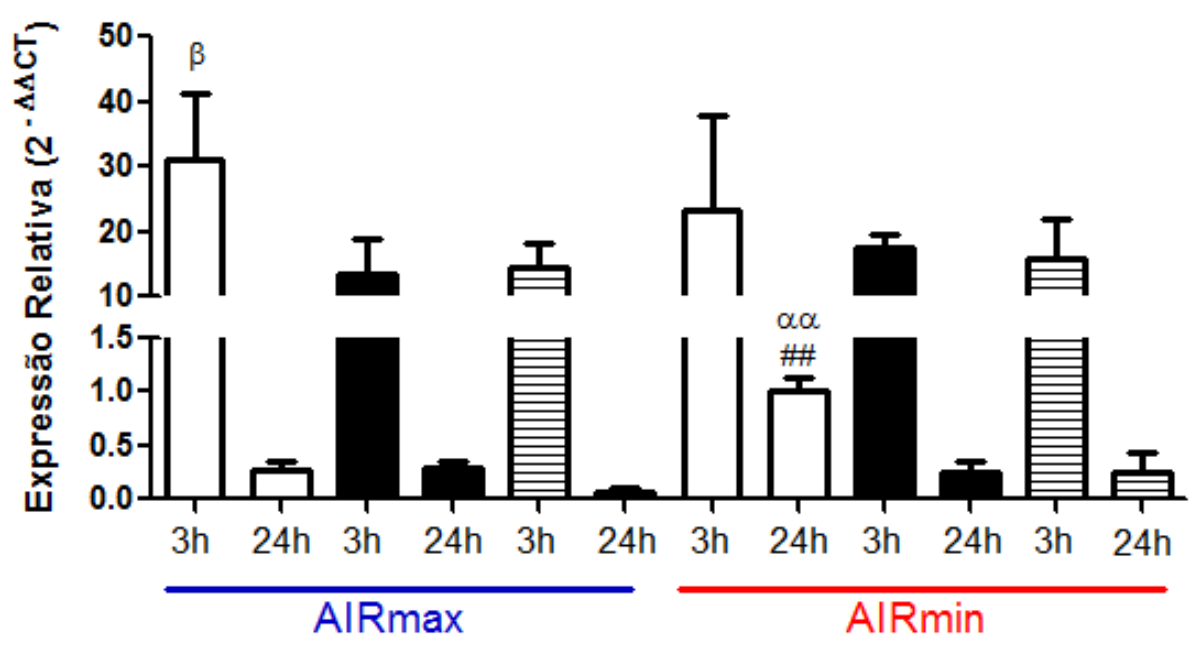

CXCL2

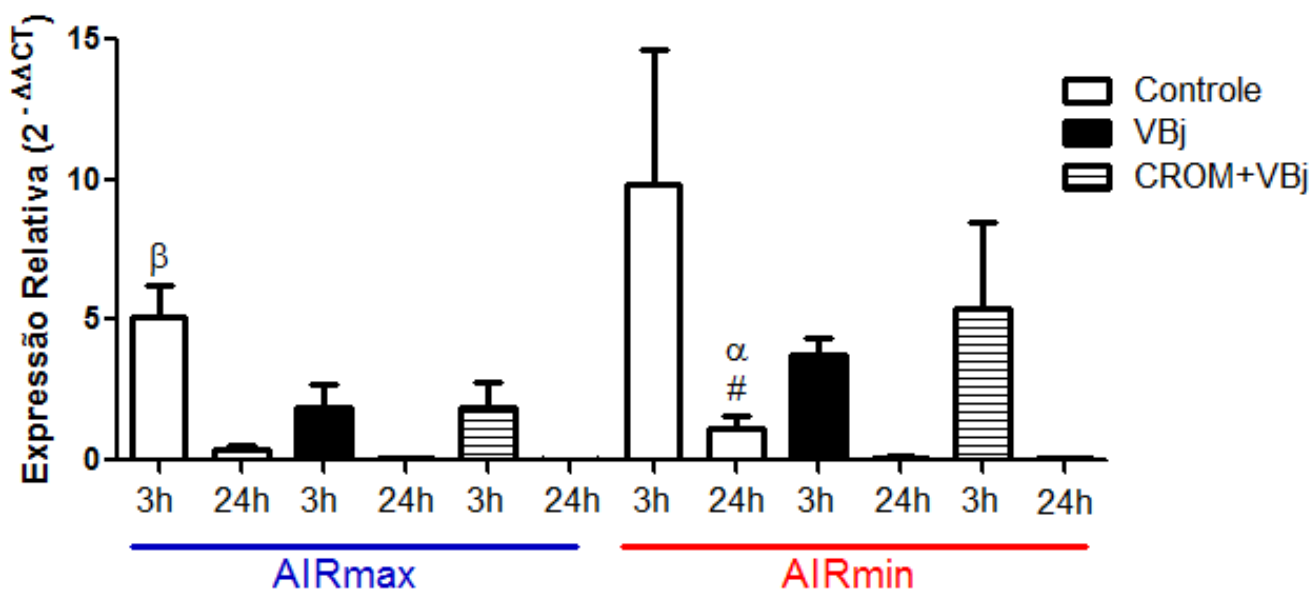

Figura 24 - Expressão relativa de quimiocinas. Quantificação da expressão relativa de CCL2 e CXCL2 em células peritoneais de animais de ambas as linhagens ( $\mathrm{n}=3$ ), pré-tratados com $100 \mathrm{mg} / \mathrm{kg}$ de CROM, coletadas 3 e 24 hs após a inoculação i.p. de VBj.

$\beta-3$ hs vs. 24 hs $(\beta p<0,05)$. \# - Controle vs. VBj \# p < 0.05). $\alpha-$ Controle vs. CROM+VBj $(\alpha p<0,05)$. Os resultados expressam média \pm e.p.m 


\subsection{Reação de Anafilaxia Cutânea Passiva (PCA)}

Para avaliar a funcionalidade dos mastócitos nas duas linhagens e a eficácia do CROM como estabilizador de mastócitos, testamos a dose de $100 \mathrm{mg} / \mathrm{kg}$ do fármaco nas reações de Anafilaxia Cutânea Passiva em animais AIRmax, AIRmin e, como controle, nos animais $\mathrm{BALB} / \mathrm{c}$.

Após o pré-tratamento com o CROM, os animais foram sensibilizados com diferentes concentrações de soro de animais imunizados com ovalbumina (1:80, 1:160 e 1:320) e, a seguir, desafiados com uma solução composta pelo corante Azul de Evans e ovalbumina. A leitura da reação foi analisada na pele invertida dos animais, sendo consideradas reações positivas as que obtiveram, no mínimo, 5 mm de diâmetro (OVARY, 1958).

A sensibilização levou à desgranulação dos mastócitos nas três linhagens, de modo a promover o extravasamento plasmático detectável pela coloração do Azul de Evans (Figura 25). Nas três linhagens, o efeito foi detectável até a diluição de 1:320 do soro. Diferentemente dos animais AIRmin (Figura 25C) e BALB/c (Figura 25E), os halos dos animais AIRmax (Figura 25A) não ficaram bem delimitados, o que indica que uma diluição ainda maior do soro seria capaz de promover a reação.

O tratamento com $100 \mathrm{mg} / \mathrm{kg}$ de CROM não foi capaz de inibir a reação nos AIRmax nem nos BALB/c, porém inibiu a reação em duas diluições dos animais AIRmin (Figura 25B, D e F). 

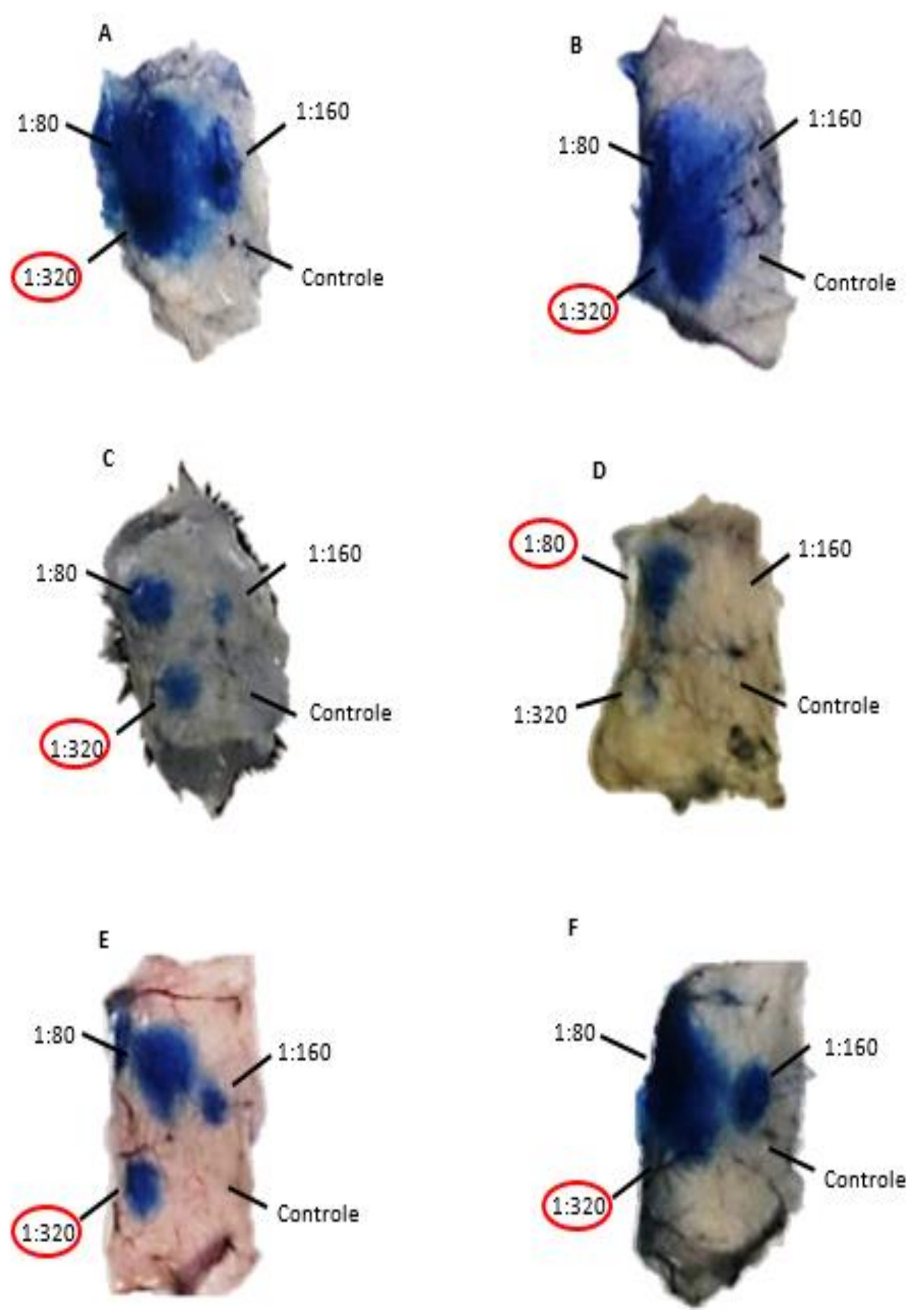

Figura 25 - Reação de Anafilaxia Cutânea Passiva. A reação foi testada em animais AIRmax (A e B), AIRmin (C e D) e BALB/c (E e F) (n=3-4). Tanto os animais AIRmax controle (A) como os tratados com CROM (B) apresentaram uma reação superior a 1:320. Os AIRmin controle (C) tiveram uma reação igual a 1:320, enquanto que os AIRmin tratados com CROM (D) tiveram uma reação igual a 1:80. Os animais BALB/c controle (E) e tratados com CROM (F) tiveram uma reação igual a 1:320. 
5 DISCUSSÃO 


\section{DISCUSSÃO}

O processo inflamatório é essencial para o combate de infecções e o reparo de injúrias no organismo. $\mathrm{O}$ estudo da inflamação nos animais selecionados para alta ou baixa reatividade inflamatória aguda (AIRmax e AIRmin) tem trazido importantes dados para a compreensão desse fenômeno.

O veneno da Bothrops jararaca (VBj) é um potente agente inflamatório. A patogênese do envenenamento por essa serpente envolve uma ação combinada de metaloproteinases, fosfolipases e serinoproteases, bem como da liberação de vários mediadores químicos oriundos do plasma ou de células inflamatórias da vítima (BONAVITA et al., 2006; GUTIÉRREZ; LOMONTE, 1995; TREBIEN; CALIXTO, 1989).

Tem sido cada vez mais evidenciada a participação dos mastócitos na inflamação em diversos cenários, uma vez que seus mediadores atuam em várias etapas desse processo (HEIB et al., 2008; STASSEN et al., 2002). Para avaliarmos o papel dos mastócitos na inflamação desencadeada pelo $\mathrm{VBj}$ nas linhagens selecionadas para diferentes capacidades de resposta inflamatória, utilizamos um fármaco estabilizador de mastócitos (Cromoglicato de Sódio CROM), mensurando diferentes aspectos da inflamação sob a ação do veneno.

Os resultados onde avaliamos o efeito da droga sob os mastócitos mesentéricos dos animais selecionados para a inflamação revelaram que CROM estabilizou parcialmente a desgranulação dos mastócitos sob o estímulo de um potente desgranulador, o Composto 48/80, e do $\mathrm{VBj}$, o que demonstrou que o tratamento possui efeito estabilizador em nível local. É importante ressaltar, no entanto, que a injeção de PBS no peritônio dos animais já foi capaz de causar desgranulação dos mastócitos mesentéricos em ambas as linhagens.

Trabalhos recentes demonstraram a participação dos mastócitos na formação de edema e dor desencadeados por toxinas de animais, tanto de espécies de serpentes (NASCIMENTO et al., 2010), como de outros animais (KIMURA et al., 2015), através da atuação de CROM. No nosso modelo animal, no entanto, o edema desencadeado pelo $\mathrm{VBj}$, não foi modulado com a utilização do CROM em nenhuma das linhagens, mesmo quando este foi administrado em maiores doses ou quando a dose do veneno foi diminuída. Já na dor, pudemos observar uma modulação significativa.

Pela primeira vez, foi avaliada a dor nas linhagens selecionadas para a inflamação, revelando que os animais AIRmax apresentam menor limiar nociceptivo (maior dor) do que os AIRmin, fato que pode estar associado ao maior nível de prostaglandina $\mathrm{E}_{2}\left(\mathrm{PGE}_{2}\right)$ observado em AIRmax após 2 e 4 hs de ação do veneno (CARNEIRO et al., 2002). Esse evento mostrou- 
se relacionado com a ação dos mastócitos, uma vez que o tratamento com CROM foi capaz de inibir parcialmente a dor, o que ocorreu por mais tempo em camundongos AIRmax do que em AIRmin. Esses resultados foram comparados com os resultados obtidos nos animais BALB/c, uma linhagem isogênica de referência, evidenciando que o limiar de dor destes animais é semelhante ao dos AIRmax, porém com menor inibição sob a ação do CROM.

A prostaglandina é um mediador lipídico produzido pelas cicloxigenases a partir do ácido aracdônico em resposta a diversos estímulos, sejam eles patogênicos (PAMPs) ou por lesões estéreis (DAMPs). A PGE 2 , um subtipo das prostaglandinas é capaz de ativar várias células, como os mastócitos, causando inflamação e dor (KAWAHARA et al., 2015). Esse efeito pode explicar a maior hiperalgesia observada nos animais AIRmax com relação aos AIRmin, bem como o fato do CROM ter sido capaz de inibir parcialmente a dor desencadeada pelo veneno.

Apesar de o edema e a dor ocorrerem concomitantemente na inflamação, a dor mostrou ser parcialmente dependente dos mediadores inflamatórios dos mastócitos, evento que já havia sido observado em ratos sob o estímulo de VBj (BONAVITA et al., 2006), enquanto que a formação do edema, não. Zichar et al., (2010) demonstraram que o edema desencadeado pelo VBj tratado com um inibidor de metaloproteinases é consideravelmente menor do que pelo veneno bruto, o que indica que apenas a ação das metaloproteinases já seria suficiente para ocasionar o edema, independente da ação dos mastócitos. Além disso, uma vez que o VBj induz uma resposta multimediada, outras células podem estar envolvidas no efeito edematogênico, como visto em macrófagos e neutrófilos em resposta a venenos, inclusive ao veneno botrópico (FURTADO et al., 2014; MOREIRA et al., 2009).

O veneno foi, então, inoculado no peritônio, onde avaliamos a migração celular no local da injeção. Após 3 hs, os animais AIRmax apresentaram um número maior de células totais que os AIRmin. A contagem diferencial indicou que os leucócitos responsáveis por esse aumento foram, principalmente, os macrófagos. Não foi observada nenhuma modulação na migração das células peritoneais com o uso de CROM após 1 e 3 hs do veneno. Após 24 hs, no entanto, o tratamento como CROM aumentou o número de macrófagos no peritônio sob a ação do veneno. O número de neutrófilos, porém, mostrou-se maior nos animais AIRmax do que nos AIRmin após 24 hs do veneno, efeito parcialmente inibido sob ação do CROM. Esses resultados estão de acordo com um estudo de Kimura et al., (2015), em que foi utilizado o veneno da arraia Potamotrygon motoro em patas de camundongos, onde o tratamento com CROM também aumentou o recrutamento de macrófagos e diminuiu o número de neutrófilos após 4 hs da injeção local do veneno. Os dados nos indicam, portanto que, nos animais AIRmax, a migração 
de neutrófilos para o foco inflamatório em resposta ao veneno depende de mediadores liberados pelos mastócitos.

A análise das subpopulações de células do peritônio mostrou que, após 3 e 24 hs do veneno, o número de mastócitos, diminui. Após 3 hs, somente, o pré-tratamento com CROM inibe esse efeito, indicando que o veneno pode estar desgranulando os mastócitos locais, desintegrando sua membrana e impedindo a sua marcação com os anticorpos monoclonais e que, 3 hs após a injeção do veneno, o CROM ainda atua nas células, inibindo esse fenômeno. A análise também evidenciou que as populações correspondentes a macrófagos e neutrófilos, após 24 hs do veneno, também são alteradas sob a ação do veneno e do CROM, e que os animais AIRmax apresentam maior número dessas células sob a ação do veneno do que os animais AIRmin.

Embora os resultados da contagem diferencial de células pela técnica da citospin e da citometria de fluxo não tenham sido semelhantes, é importante ressaltar a diferença entre as técnicas. A citospin é uma técnica mais rápida, no entanto, vários fatores podem interferir na contagem, como o processo de centrifugação e coloração e a diferença de interpretação dos elementos celulares ao microscópio. A citometria de fluxo, por sua vez, utiliza marcadores específicos e sua análise é capaz de restringir com maior precisão as populações celulares. Ambas as técnicas, no entanto, ofereceram informações importantes para o presente estudo, apontando que o veneno e o CROM alteram o perfil celular local.

Avaliando o estado de ativação das células que migraram através da quantificação da produção de ROS sob o estímulo de PMA, detectamos que, 24 hs após a injeção do veneno, os animais AIRmax produzem mais ROS do que os AIRmin. O pré-tratamento com CROM é capaz de inibir essa produção na linhagem AIRmax no mesmo período. Esse resultado pode estar relacionado com o aumento de neutrófilos e macrófagos 24 hs após o veneno, uma vez que essas células são as principais produtoras de ROS.

Uma vez que os mastócitos liberam uma variedade de citocinas e que elas desempenham um papel importante na fisiopatologia do envenenamento ofídico (AVILA-AGUERO et al., 2001; BARRAVIERA et al., 1995), analisamos a produção e a expressão das citocinas próinflamatórias IL-1 $\beta$, IL-6 e TNF- $\alpha$ da citocina anti-inflamatória IL-10.

A análise da produção e liberação de citocinas não apontou diferenças significativas entre os grupos de tratamento ou entre as linhagens. A expressão gênica das citocinas próinflamatórias, porém, mostrou-se mais intensa 3 hs após a inoculação de PBS do que 24 hs depois, indicando um tipo de resposta mais imediata. Surpreendentemente, porém, a inoculação do veneno não alterou o perfil de expressão dessas citocinas em nenhum dos dois horários 
analisados e em nenhuma das linhagens, exceto no caso da expressão de IL-6, em que o veneno suprimiu a expressão dessa citocina. $\mathrm{O}$ tratamento com CROM modulou apenas a expressão de IL-1 $\beta$ nos animais AIRmin 3 hs após o veneno, aumentando a expressão dessa citocina com relação aos animais AIRmax e às 24 hs. A expressão da citocina anti-inflamatória IL-10 não foi modulada com os diferentes tratamentos, nem mostrou diferença entre as linhagens sob essas condições.

Estudos experimentais demonstraram que, em alguns cenários, o veneno botrópico é capaz de aumentar os níveis de citocinas em camundongos. É o caso do veneno da serpente Bothrops asper, injetado na pata, em que o nível sérico de IL-6 aumenta após 3 e 6 hs (LOMONTE et al., 1993); do veneno de Bothrops atrox, injetado no peritônio, que aumenta o nível sérico de IL-6, IL-10 e TNF- $\alpha$ (BARROS et al., 1998); e mesmo do veneno bruto da Bothrops jararaca, injetado no peritônio com a dose letal mediana $\left(\mathrm{LD}_{50}\right)$, em que ocorre o aumento de IL-1 $\beta$, IL-6, IL-10 e TNF- $\alpha$ no soro (PETRICEVICHA et al., 2000). Semelhantemente, a jararagina, uma metaloproteinase isolada do VBj, injetada i.p., também aumenta o nível de TNF- $\alpha$ e IL-1 $\beta$ em cultura de células aderentes 4 e 24 hs, respectivamente (CLISSA et al., 2001).

No nosso modelo animal, Carneiro et al., (2002; 2008) demonstraram que a injeção i.p do VBj aumentou o nível de IL-6 no sobrenadante de células peritoneais após 4 e 8 hs em ambas as linhagens. O nível de TNF- $\alpha$, medido pelo ensaio biológico de citotoxicidade, aumentou nos animais AIRmax em relação aos AIRmin após 8 hs. Quando analisado o sobrenadante do macerado de patas injetadas com o VBj, foi observado que os animais AIRmax apresentam um aumento da liberação de IL-1 $\beta$ e IL-6 após 1, 3 e 6 hs, enquanto que os AIRmin apenas 3 e 6 hs da injeção do veneno.

Foram analisadas também a expressão de duas quimiocinas, uma com ação quimiotática para mastócitos (CCL2), e outra liberada por mastócitos, com ação quimiotática para neutrófilos, (CXCL2). A análise revelou que ambas as quimiocinas têm maior expressão 3 hs após a injeção de PBS do que após 24 hs nos animais AIRmax, indicando um efeito mais imediato para a quimiotaxia dessas células. Nos animais AIRmin, há uma maior expressão de CCL2 após 24 hs da injeção de PBS do que da injeção do veneno, mesmo em animais prétratados com CROM. Esse resultado parece indicar que o sinal quimiotático para mastócitos ocorre concomitantemente com o sinal quimiotático para os neutrófilos liberados por essas células para o local da injeção de VBj.

Tomados em conjunto esses dados nos mostraram que os animais AIRmax e AIRmin diferiam quanto a ativação dos mastócitos e quanto à eficácia do CROM na inibição dessa 
ativação. Em um teste clássico de anafilaxia, o PCA, cujo resultado é dependente da desgranulação dos mastócitos, pudemos observar um extravasamento mais intenso nos animais AIRmax comparado com os AIRmin, embora ambos tenham tido reação sob a mesma diluição do soro utilizado, confirmando a diferença de AIRmax e AIRmin quanto a liberação dos mediadores inflamatórios do mastócito. O tratamento com o CROM, no entanto, foi eficaz para inibição parcial dessa reação apenas em AIRmin.

A eficácia de CROM em camundongos foi questionada em um trabalho de Oka et al., (2012), onde mesmo com altas doses da droga não houve a inibição da desgranulação dos mastócitos. Estudos anteriores haviam demonstrado que o CROM teria efeitos inibitórios em algumas funções dos mastócitos, mas não em outras (KOBAYASHI et al., 1993; MARQUARDT et al., 1986). Somado a isso, existem diferentes subtipos de mastócitos encontrados em camundongos que possuem sensibilidade diferenciada à droga (METCALFE et al., 1997). Esses fatos podem explicar a divergência das respostas encontradas nos sucessivos experimentos, onde CROM atuou com diferentes intensidades ou mesmo foi ineficaz.

Nossos resultados mostraram que os mastócitos desempenham um papel importante na migração celular, na ativação para a produção de reativos do oxigênio e no controle da dor desencadeado pelo veneno.

Os animais AIRmax possuem mastócitos mais sensíveis para desgranulação do que os AIRmin, e o tratamento com o CROM atuou de forma significativa com relação à modulação da dor, inibição da migração de neutrófilos e produção de ROS, sugerindo que a seleção genética para obtenção dos animais AIRmax e AIRmin baseada na intensidade da resposta inflamatória, interferiu na reatividade dos mastócitos. 
6 CONCLUSÃO 


\section{CONCLUSÃO}

$\checkmark$ O efeito edematogênico ocasionado pelo VBj não foi diferente entre AIRmax e AIRmin; os mastócitos não modularam essa reação.

$\checkmark$ Animais AIRmax são mais nociceptivos que os animais AIRmin; a hiperalgesia ocasionada pelo VBj é maior em AIRmax do que em AIRmin; os mastócitos participam dos eventos mais imediatos da dor em ambas as linhagens.

$\checkmark$ O número de neutrófilos e macrófagos recrutados sob o estímulo do VBj é maior em AIRmax do que em AIRmin; os mastócitos têm participação nesse recrutamento nos animais AIRmax.

$\checkmark$ A ativação dos leucócitos sob a ação do VBj é maior em AIRmax do que em AIRmin; os mastócitos participam dessa ativação nos animais AIRmax.

$\checkmark$ Os mastócitos dos animais AIRmax são sensíveis para desgranulação que os dos AIRmin em reações anafiláticas. 
REFERÊNCIAS 


\section{REFERÊNCIAS*}

ABRAHAM, S. N.; JOHN, A. L. S. Mast cell-orchestrated immunity to pathogens. Nature Reviews - Immunology, v. 10, p. 440-452, 2010.

ABRAHAM, S. N.; MALAVIYA, R. Mast cells in infection and immunity. Infection and Immunity, v. 65, p. 3501-3508, 1997.

ALDENBORG, F.; ENERBACK, L. Thymus dependence of connective tissue mast cells: a quantitative cytofluorometric study of the growth of peritoneal mast cells in normal and athymic rats. International Archives of Allergy and Immunology. v. 78, p. 277-282, 1985.

ARAÚJO, L. M.; RIBEIRO, O. G.; SIQUEIRA, M.; STAROBINAS, N.; MASSA, S.; CABRERA, W. H.; MOUTON, D.; SEMAN, M.; IBAÑEZ, O. M. Innate resistance to infection by intracellular bacterial pathogens differs in mice selected for maximal acute inflammatory response. European Journal of Immunology, v. 28, p. 2913-2920, 1998.

AVILA-AGUERO, M. L.; PARÍS, M. M.; PETERSON, P. K.; GUTIÉRREZ, J. M.; LOMONTE, B.; FAINGEZICHT, I. Systemic cytokine response in children bitten by snakes in Costa Rica. Pediatric Emergency Care, v. 17, p. 425-429, 2001.

BARBOSA, A. M.; DO AMARAL, R. O.; TEIXEIRA, C. F.; HYSLOP, S.; COGO, J. C. Pharmacological characterization of mouse hind paw oedema induced by Bothrops insularis (jararaca ilhoa) snake venom. Toxicon, v. 42, p. 515-523, 2003.

BARRAVIERA, B.; LOMONTE, B.; TARKOWSKI, A.; HANSON, L. A.; MEIRA, D. A. Acute-phase reactions, including cytokines, in patients bitten by Bothrops and Crotalus snakes in Brazil. Journal of Venomous Animals and Toxins, v. 1, p. 11-22, 1995.

BARROS, S. F.; FRIEDLANSKAIA, I.; PETRICEVICH, V. L.; KIPNIS, T. L. Local inflammation, lethality and cytokine release in mice injected with Bothrops atrox venom. Mediators of Inflammation, v. 7, p. 339-346, 1998.

BERAHOVICH, R. D.; MIAO, Z.; WANG, Y.; PREMACK, B.; HOWARD, M. C.; SCHALL, T. J. Proteolytic activation of alternative CCR1 ligands in inflammation. Journal of Immunology, v. 174, p. 7341-7351, 2005.

BIEDERMANN, T.; KNEILLING, M.; MAILHAMMER, R.; MAIER, K.; SANDER, C. A.; KOLLIAS, G.; KUNKEL, S. L.; HULTNER, L.; ROCKEN, M. Mast Cells Control Neutrophil Recruitment during T Cell-Mediated Delayed-Type Hypersensitivity Reactions through Tumor Necrosis Factor and Macrophage Inflammatory Protein 2. The Journal of Experimental Medicine, v. 192, n. 10, p. 1441-1452, 2000.

*De acordo com:

ASSOCIAÇÃO BRASILEIRA DE NORMAS TÉCNICAS. NBR 6023: informação e documentação:

referências: elaboração. Rio de Janeiro, 2002 
BIENSTOCK, J.; BEFUS, A. D.; DENBURG, J. A. Mast cell heterogeneity: basic questions and clinical implications. In: BEFUS, A.D.; BIENENSTOCK, J.; DENBURG, J. A. Mast cell differentiation and heterogeneity. New York: Raven Press, 1982. p. 300-391.

BIOZZI, G.; RIBEIRO, O. G.; SARAN, A.; ARAUJO, L. M.; MARIA, D. A.; DE FRANCO, M.; CABRERA, W. H.; SANT'ANNA, O. A.; MASSA, S.; COVELLI, V. Effect of genetic modification of acute inflammatory responsiveness on tumorigenesis in the mouse. Carcinogenesis, v. 19, p. 337-346, 1998.

BONAVITA, A. G.; DA COSTA, A. S.; PIRES, A. L.; NEVES- FERREIRA, A. G.; PERALES, J.; CORDEIRO, R. S.; MARTINS, M. A.; SILVA, P. M. Contribution of mast cells and snake venom metalloproteinases to the hyperalgesia induced by Bothrops jararaca venom in rats. Toxicon, v. 47, p. 885-893, 2006.

BORGHERESI, R. A. M. B.; PALMA, M. S.; DUCANCEL, F.; CAMARGO, A. C. M.; CARMONA, E. Expression and processing of recombinant sarafotoxins precursor in Pichia pastoris. Toxicon, v. 39, n. 8, p. 1211-1218, 2001.

CANHAMERO, T.; REINES, B.; PETERS, L. C.; BORREGO, A.; CARNEIRO, P. S.; ALBUQUERQUE, L. L.; CABRERA, W. H.; RIBEIRO, O. G.; JENSEN, J. R.; STAROBINAS, N.; IBAÑEZ, O. M.; DE FRANCO, M. Distinct early inflammatory events during ear tissue regeneration in mice selected for high inflammation bearing Slc11a1 $\mathrm{R}$ and $\mathrm{S}$ alleles. Inflammation, v. 34, p. 303-313, 2011.

CANHAMERO, T.; GARCIA, L. V.; DE FRANCO, M. Acute inflammation loci are involved in wound healing in the mouse ear punch model. [Review] Advances in Wound Care (New Rochelle), v. 3, p. 582-591, 2014.

CARNEIRO, A. S.; RIBEIRO, O. G.; DE FRANCO, M.; CABRERA, W. H. K.; SIQUEIRA, M.; IBAÑEZ, O. M.; STAROBINAS, N. Local inflammatory reaction induced by Bothrops jararaca venom differs in mice selected for accute inflammatory response. Toxicon, v. 40, p. 1571-1579, 2002.

CARNEIRO, A. S.; RIBEIRO, O. G.; CABRERA, W. H.; VORRARO, F.; DE FRANCO, M.; IBAÑEZ, O. M.; STAROBINAS, N. Bothrops jararaca venom (BjV) induces differential leukocyte accumulation in mice genetically selected for acute inflammatory reaction: the role of host genetic background on expression of adhesion molecules and release of endogenous mediators. Toxicon, v. 52, p. 619-627, 2008.

CHATTERJEA, D.; MARTINOV, T. Mast cells: Versatile gatekeepers of pain. Molecular Immunology, v. 63, p. 38-44, 2015.

CLISSA, P. B.; LAING, G. D.; THEAKSTON, R. D. G.; MOTA, I.; TAYLOR, M. J.; MOURA-DA-SILVA, A. M. The effect of jararhagin a metalloproteinase from Bothrops jararaca venom, on pro-inflammatory cytokines released by murine peritoneal adherent cells. Toxicon, v. 48, p. 1567-1573, 2001.

DAHLGREN, C.; KARLSSON, A. Respiratory burst in human neutrophils. Journal of Immunological Methods, v. 232, p. 3-14, 1999. 
DE FARIA, L.; ANTUNES, E.; BOM, C.; DE ARAUJO, A.L. Pharmacological characterization of the rat paw oedema induced by Bothrops lanceolatus (Fer de lance) venom. Toxicon, v. 39, p. 825-830, 2001.

DE FILIPPO, K.; DUDECK, A.; HASENBERG, M.; NYE, E.; ROOIJEN, N. V.; HARTMANN, K.; GUNZER, M.; ROERS, A.; HOGG, N. Mast cell and macrophage chemokines CXCL1/CXCL2 control the early stage of neutrophil recruitment during tissue inflammation. Blood, v. 121, p. 4930-4937, 2013.

DE FRANCO, M.; CARNEIRO, P. S.; PETERS, L. C.; VORRARO, F.; BORREGO, A.; RIBEIRO, O. G.; STAROBINAS, N.; CABRERA, W. K.; IBAÑEZ, O. M. Slc1 lal (Nramp1) alleles interact with acute inflammation loci to modulate wound healing traits in mice. Mammalian Genome, v. 18, p. 263-269, 2007.

DOENER, F.; MICHEL, A.; REUTER, S.; FRIEDRICH, P.; BOHM, L.; RELLE, M.; CODARRI, L.; TENZER, S.; KLEIN, M.; BOPP, T.; SCHMITT, E.; SCHILD, H.; RADSAK, M. P.; TAUBE, C.; STASSEN, M.; BECKER, M. Mast cell-derived mediators promote murine neutrophil effector functions. International Immunology, v. 25, p. 553-561, 2013.

DOS SANTOS, J. I.; CARDOSO, F. F.; SOARES, A. M.; DAL PAI SILVA, M.; GALLACCI, M.; FONTES, M. R. Structural and functional studies of a bothropic myotoxin complexed to rosmarinic acid: new insights into Lys49-PLA2 inhibition. PLoS One, v. 6, n. 12, 2011.

DRAY, A. Inflammatory mediators of pain. British Journal of Anesthesia, v. 75, p. 125-131, 1995.

DUFFY, S. M.; BERGER, P.; CRUSE, G.; YANG, W.; BOLTON, S. J.; BRADDING, P. The $\mathrm{K}^{+}$channel iKCA1 potentiates $\mathrm{Ca}^{2+}$ influx and degranulation in human lung mast cells. Journal of Allergy and Clinical Immunology, v.114, p. 66-72, 2004.

DVORAK, A. M.; MASSEY, W.; WARNER, J.; KISSELL, S.; KAGEY-SOBOTKA, A.; LICHTENSTEIN, L. M. IgE-mediated anaphylactic degranulation of isolated human skin mast cells. Blood, v. 77, p. 569-578, 1991.

FERNANDES, J. G.; CANHAMERO, T.; BORREGO, A.; JENSEN, J. R.; CABRERA, W. H.; CORREA, M. A.; STAROBINAS, N.; RIBEIRO, O. G.; IBAÑEZ, O. M.; DE FRANCO, M. Distinct gene expression profiles provoked by polyacrylamide beads (Biogel) during chronic and acute inflammation in mice selected for maximal and minimal inflammatory responses. Inflammation Research, v. 65, p. 313-323, 2016.

FORSYTHE, P.; BIENENSTOCK, J. The mast cell-nerve functional unit: A key component of physiologic responses. Chemical Allergy and Immunology, v. 98, p. 196-221, 2012.

FOX, J. W.; SERRANO, S. M. T. Structural considerations of the snake venom metalloproteinases, key members of the M12 reprolysin family of metalloproteinases. Toxicon, v. 45, p. 969-985, 2005.

FREITAS, M.; LIMA, J. L. F. C, FERNANDES, E. Optical probes for detection and quantification of neutrophils' oxidative burst. A review. Analytica Chimica Acta, v. 649, p. $8-23,2009$. 
FROSSI, B.; D'INCA, F.; CRIVELLATO, E.; SIBILANO, R, GRI, G.; MONGILLO, M.; DANELLI, L.; MAGGI, L.; PUCILLO, C. E. Single-cell dynamics of mast cell-CD4+ CD25+ regulatory T cell interactions. European Journal of Immunology, v. 41, p. 1872-1882, 2011.

FURTADO, J. L.; OLIVEIRA, G. A.; PONTES, A. S.; SUTÚBAL, S. S.; XAVIER, C. V.; LACOUTH-SILVA, F. LIMA, B. F.; ZAQUEO, K. D.; KAYANO, A. M.; CALDERON, L. A.; STÁBELI, R. G.; SOARES, A. M.; ZULIANI, J. P. Activation of J77A.1 macrophages by three phospholipases A2 isolated from Bothrops atrox snake venom. BioMed Research International, 2014. http://dx.doi.org/10.1155/2014/683123.

GALLI, S. J.; TSAI, M. Mast cells: Versatile regulators of inflammation, tissue remodeling, host defense and homeostasis. Journal of Dermatological Science, v. 49, p. 7-19, 2008.

GALLI, S. J.; BORREGAARD, N.; WYNN, T. A. Phenotypic and functional plasticity of cells of innate immunity: macrophages, mast cells and neutrophils. Nature Immunology, v. 12, p. 1035-1044, 2011.

GILROY, D. M.; LAWRENCE, T.; PERRETTI, M.; ROSSI, A. G. Inflammatory resolution: New opportunities for drug discovery. Nature Reviews Drug Discovery, v. 3, p. 401-416, 2004.

GUTIÉRREZ, J. M. Phospholipase A2 myotoxins from Bothrops snake venoms. Toxicon, v. 33, p. 1405-1424, 1995.

GUTIÉRREZ, J.M.; LOMONTE, B. Phospholipase A2 myotoxins from Bothrops snake venoms. Toxicon, v. 33, p.1405-1424, 1995.

GUTIÉRREZ, J. M.; OWNBY, C. L. Skeletal muscle degeneration induced by venom phospholipases A2: insights into the mechanisms of local and systemic myotoxicity. Toxicon, v.42, p. 915-931, 2003.

GOUREVITCH, D.; CLARK, L.; CHEN, P.; SEITZ, A.; SAMULEWICZ, S. J.; HEBERKATZ, E. Matrix metalloproteinase activity correlates with blastema formation in the regenerating MRL mouse ear hole model. Developmental Dynamics, v. 226, p. 377-387, 2003.

HATANAKA, E. LEVADA-PIRES, A. C.; PITHON-CURI, T. C.; CURI, R. Systematic study on ROS production induced by oleic, linoleic, and $\gamma$-linolenic acids in human and rat neutrophils. Science Direct, v. 41, p. 1124-1132, 2006.

HEIB, V.; BECKER, M.; TAUBE, C.; STASSEN, M. Advances in the understanding of mast cell function. British Journal of Haematology, v. 142, n.5, p. 683-694, 2008.

HENDRIX, S.; KRAMER, P.; PEHL, D.; WARNKE, K.; BOATO, F.; NELISSEN, S.; LEMMENS, E.; PEJLER, G.; METZ, M.; SIEBENHAAR, F.; MAURER, M. Mast cells protect from post-traumatic brain inflammation by the mast cell-specific chymase mouse mast cell protease-4. FASEB Journal, v. 27, p. 920-929, 2013.

HOFSTRA, C. L.; DESAI, P. J.; THURMOND, R. L.; FUNG-LEUNG, W. P. Histamine H4 receptor mediates chemotaxis and calcium mobilization of mast cells. The Journal of Pharmacology and Experimental Therapeutics, v. 305, n. 3, p. 1212-1221, 2003. 
IBAÑEZ, O. M.; STIFFEL, C.; RIBEIRO, O. G.; CABRERA, W. H.; MASSA, S.; DE FRANCO, M.; SANT'ANNA, O. A.; DECREUSEFOND, C.; MOUTON, D.; SIQUEIRA, M.; BIOZZI, G. Genetics of nonspecific immunity: I. Bidirectional selective breeding of lines of mice endowed with maximal or minimal inflammatory responsiveness. European Journal of Immunology, v. 22, p. 2555-2563, 1992.

IWAMOTO, S.; ASADA, Y.; EBIHARA, N.; HORI, K.; OKAYAMA, Y.; KASHIWAKURA, J.; WATANABE, Y.; KAWASAKI, S.; YOKOI, N.; INATOMI, T.; SHINOMIYA, K.; MURAKAMI, A.; MATSUDA, A. Interaction between conjunctival epithelial cells and mast cells induces CCL2 expression and piecemeal degranulation in mast cells. Investigative Ophthalmology and Visual Science, v. 54, p. 2465-2473, 2013.

KNEILLING, M. AND ROCKEN, M. Mast cells: Novel clinical perspectives from recent insights. Experimental Dermatology, v. 18, n. 5, p. 488-496, 2009.

KAMIGUTI, A. S.; HAY, C. R.; ZUZEL, M. Inhibition of collagen-induced platelet aggregation as the result of cleavage of alpha 2 beta 1 - integrin by the snake venom metalloproteinase jararhagin. Biochemical Journal, v. 320 (Pt 2), p. 635-641, 1996.

KAMIGUTI, A. S.; SLUPSKY, J. R.; ZUZEL, M.; HAY, C. R. Properties of fibrinogen cleaved by jararhagin, a metalloproteinase from the venom of Bothrops jararaca. Thrombosis and Haemostasis, v. 72, p. 244-249, 1994.

KAWAHARA, K.; HOHJOHA, H.; INAZUMIA, T.; TSUCHIYA, S.; YUKIHIKO, S. Prostaglandin E2-induced inflammation: Relevance of prostaglandin E receptors. Biochimica et Biophysica Acta (BBA) - Molecular and Cell Biology of Lipids, v. 1851, p. 414-421, 2015.

KIMURA, L. F.; PREZOTTO-NETO, J. P.; TÁVORA, B. C. L. F.; FAQUIM-MAURO, E. L.; PEREIRA, N. A.; ANTONIAZZI, M. M.; JARED, S. G. S.; TEIXEIRA, C. F. P.; SANTORO, M. L.; BARBARO, K. C. Mast cells and histamine play an important role in edema and leukocyte recruitment induced by Patamotrygon motoro stingray venom in mice. Toxicon, v. 103, p. 65-73, 2015.

KOBAYASHI, K.; HIROI, J.; KISHI, S. SAWASE, K.; HIRAYAMA, Y.; CHIHARA, S.; IMAI, T.; SHIGI, Y.; SHIMOMOURA, K.; KOHSAKA, M. Effects of quinotolast, a new orally active antiallergic drug, on experimental allergic models. Japanese Journal of Pharmacology, v. 63 , p. 73-81, 1993.

LAW, J. K. Y.; YEUNG, C. K.; WAN, S. P.; INGEBRANDT, S.; LAU, H. Y. A.; RUDD, J. A.; CHAN, M. The significance of chloride in the inhibitory action of disodium cromoglycate on immunologically-stimulated rat peritoneal mast cells. Biochimica et Biophysica Acta, v. 1810, p. 867-874, 2011.

LIVAK, K. J.; SCHMITTGEN, T. D. Analysis of relative gene expression data using real-time quantitative PCR and the 2[-Delta Delta C(T)]. Methods.; v. 25, p. 402-408, 2001.

LOMONTE, B. TARKOWSKI, A.; HANSON, L. A. Host response to Bothrops asper snake venom. Analysis of edema formation, inflammatory cells, and cytokine release in a mouse model. Inflammation, v. 7, p. 93-105, 1993. 
MALAVIYA, R.; MALAVIYA, R.; JAKSCHIK, B. A. Control of mast-cell 5-lipoxygenase. American Journal of Therapeutics, v. 4, p. 225-228, 1997.

MARQUARDT, D. L.; WALKER, L. L.; WASSERMAN, S. I. Cromolyn inhibition of mediator release in mast cells derived from mouse bone marrow. The American Review of Respiratory Disease, v. 133, p. 1105-1109, 1986.

MATSUI, T.; FUJIMURA, Y.; TITANI, K. Snake venom proteases affecting hemostasis and thrombosis. Biochimica et Biophysica Acta, v. 1477, p. 146-156, 2000.

MCCURDY, J. D.; OLYNYCH, T. J.; MAHER, L. H.; MARSHALL, J. S. Cutting edge: distinct Toll-like receptor 2 activators selectively induce different classes of mediator production from human mast cells. Jounal of Immunology, v. 170, p.1625-1629, 2003.

MEBS, D.; OWNBY, C. L. Myotoxic components of snake venoms: their biochemical and biological activities. Pharmacology and Therapeutics, v. 48, p. 223-236, 1990.

MEKORI, Y. A.; METCALFE, D. D. Mast cells in innate immunity. Immunological Reviews, v. 173, p. 131-140, 2000.

METCALFE, D. D.; BARAM, D.; MEKORI, Y. A. Mast cells. Physiological reviews, v. 77, n. 4, p. 1033-1079, 1997.

METZ, M.; PILIPONSKY, A. M.; CHEN, C. C.; LAMMEL, V.; ABRINK, M.; PEJLER, G.; TSAI, M.; GALLI, S. J. Mast cells can enhance resistance to snake and honeybee venoms. Science, v. 313, p. 526-530, 2006.

METZ, M.; MAURER, M. Mast cells-key effector cells in immune responses. Trends in Immunology, v. 28, n. 5, p. 234-241, 2007.

MILLER, H. R. P.; J. F. HUNTLEY, G. F. J. NEWLANDS, A. MACKELLAR, J. IRVINE, D. M. HAIG, A. MACDONALD, A. D. LAMMAS, D. WAKELIN, AND R. G. WOODBURY. Mast cell granule proteases in mouse and rat: a guide to mast cell heterogeneity and activation in the gastrointestinal tract. In: GALLI, S. J.; AUSTEN, K. F. Mast Cell and Basophil Differentiation and Function in Health and Disease, New York: Raven, 1989. p. 81.

MINISTÉRIO DA SAÚDE. Manual de diagnóstico e tratamento de acidentes por animais peçonhentos. $2^{\mathrm{a}}$ ed. Brasília: Fundação Nacional de Saúde, 2001. 120 p.

MINISTÉRIO DA SAÚDE. Secretaria de Vigilância em Saúde. Série A. Normas e Manuais Técnicos $7^{\mathrm{a}}$ ed. Brasília: Departamento de Vigilância Epidemiológica, 2009. 816 p.

MINISTÉRIO DA SAÚDE. Notificações registradas no Sistema de Notificação de Agravos de Notificação - SINAN NET, 2014. Disponível em: <http://dtr2004.saude.gov.br/sinanweb/tabnet/dh?sinannet/animaisp/bases/animaisbrnet.def>. Acesso em: 11 jun. 2015.

MOON, C. T.; BEFUS, D. A.; KULKA, M. Mast cells mediators: their differential realease and the secretory pathways involved. Frontiers in Immunology, v. 5, article 569, 2014. 
MOREIRA, V.; GUTIÉRREZ, J. M.; AMARAL, R. B.; ZAMUNÉR, S. R.; TEIXEIRA, C. F. Effects of Bothrops asper snake venom on the expression of cyclooxygenases and production of prostaglandins by peritoneal leukocytes in vivo, and by isolated neutrophils and macrophages in vitro. Prostaglandin, Leukotrienes, and Essential Fatty Acids, v. 80, p. 107-114, 2009. MOTA, I. The mechanism of anaphylaxis: Prodution and biological properties of 'mast cell sensitizing' antibody. Immunology, v. 7, p. 681-699, 1964.

MOURA-DA-SILVA, A. M.; LAING, G. D.; PAINE, M. J.; DENNISON, J. M.; POLITI, V.; CRAMPTON, J. M.; THEAKSTON, R. D. Processing of pro-tumor necrosis factor-alpha by venom metalloproteinases: a hypothesis explaining local tissue damage following snakebite. European Journal of Immunology, v. 26, p. 2000-2005, 1996.

NAKAE, S.; HO, L. H.; MONTEFORTE, R.; IIKURA, M.; SUTO, H.; GALLI, S. J. Mast cellderived TNF contributes to airway hyperreactivity, inflammation, and TH2 cytokine production in an asthma model in mice. The Journal of Allergy and Clinical Immunology, v. 120, p. 48$55,2007$.

NASCIMENTO, N. G.; SAMPAIO, M. C.; OLIVO, R. A.; TEIXEIRA, C. Contribution of mast cells to the oedema induced by Bothrops moojeni snake venom and a pharmacological assessment of the inflammatory mediators involved. Toxicon, v. 55, p. 343-352, 2010.

NELISSEN, S.; VANGANSEWINKEL, T.; GEURTS, N.; GEBOES, L.; LEMMENS, E.; WILLEMS, L.; BOATO, F.; DOOLEY, D.; PEHL, D.; PEJLER, G.; MAURER, M.; METZ, M.; HENDRIX, S. Mast cells protect from post-traumatic spinal cord damage in mice by degrading inflammation-associated cytokines via mouse mast cell protease 4 . Neurobiology of Disease, v. 62, p. 260-272, 2013.

NEMETH, A.; MAGYAR, Z.; HUSZTI, Z. Inhibition of potassium-induced release of histamine from mast cells by tetraethylammonium and tetramethylammonium. Agents Actions, v. 30, p. 143-145, 1990.

NORRIS, A. A.; ALTON, E. W. Chloride transport and the action of sodium cromoglycate and nedocromil sodium in asthma. Clinical and Experimental Allergy, v.26, p. 250-253, 1996.

OKA, T.; KALESNIKOFF, J;. STARKL, P.; TSAI, M.; GALLI, S. J. Evidence questioning cromolyn's effectiveness and selectivity as a 'mast cell stabilizer' in mice. Laboratory Investigation, v. 92, p. 1472-1482, 2012.

OLIVEIRA, F. N.; BRITO, M. T.; MORAIS, I. C. O.; FOOK, S. M. L.; ALBUQUERQUE, H. N. Accidents caused by Bothrops and Bothropoides in the State of Paraiba: epidemiological and clinical aspects. Revista da Sociedade Brasileira de Medicina Tropical, v. 43, n. 6, p. 662-667, 2010.

OLIVO, R. A.; TEIXEIRA, C. F.; WALLACE, J. L.; GUTIÉRREZ, J. M.; ZAMUNER, S. R. Role of cyclooxygenases in oedema-forming activity of bothropic venoms. Toxicon, v. 49, p. 670-677, 2007.

OVARY, Z. Passive cutaneous anaphylaxis in the mouse. Journal of Immunology, v. 81, n. 4, p.355-357, 1958. 
PÁLMAI-PALLAG, T.; BACHRATI, C. Z. Inflammation-induced DNA damage and damageinduced inflammation: a vicious cycle. Microbes and infection, v. 16, p. 822-832, 2014.

PETRICEVICHA, V. L.; TEIXEIRA, C. F. P.; TAMBOURGIA, D. V.; GUTIÉRREZ, J. M. Increments in serum cytokine and nitric oxide levels in mice injected with Bothrops asper and Bothrops jararaca snake venoms. Toxicon, v. 38, p. 1253-1266, 2000.

QIAN, Y.X.; MCCLOSKEY, M.A. Activation of mast cell $\mathrm{K}^{+}$channels through multiple G protein-linked receptors. Proceedings of the National Academy of Sciences U.S.A., v. 90, p. 7844-7848, 1993.

REN, K.; DUBNER, R. Interactions between the immune and nervous system in pain. Nature Medicine, v. 16, p. 1267-1276, 2010.

RIBEIRO, O. G.; MARIA, A. D.; ADRIOUCH, S.; PECHBERTY, S.; CABRERA, W. H. K.; MORISSET, J.; IBAÑEZ, O. M.; SEMAN, M. Convergent alteration of granulopoiesis, chemotactic activity, and neutrophil apoptosis during mouse selection for high acute inflammatory response. Journal of Leukocite Biology, v. 74, p. 497-506, 2003.

RIVERA, J.; OLIVERA, A. A current understanding of Fc epsilon RI-dependent mast cell activation. Current Allergy and Asthma Reports, v.8, p.14-20, 2008.

ROMANIN, C.; REINSPRECHT, M.; PECHT, I.; SCHINDLER, H. Immunologically activated chloride channels involved in degranulation of rat mucosal mast cells. The EMBO Journal, v.10, p. 3603-3608, 1991.

SANTORO, M. L.; SANO-MARTINS, I. S. Distúrbios hemostáticos em envenenamentos por animais peçonhentos no Brasil. In: CARDOSO, J. L. C.; FRANÇA, F. O.; FAN, H. W.; MÁLAQUE, C. M. S.; HADDAD Jr, B. (Eds.), Animais peçonhentos no Brasil: Biologia, Clínica e Terapêutica dos Acidentes. São Paulo: Sarvier, 2003. p. 289-309.

SECRETARIA DA SAÚDE, Paraná. (Ofidios) Acidente botrópico. Disponível em $<$ http://www.saude.pr.gov.br/modules/conteudo/conteudo.php?conteudo=1461 >. Acessado em: 23/06/2015.

SERRANO, S. M. T. The long road of research on snake venom serine proteinases. Toxicon, v. 62, p. 19-26, 2013.

STASSEN, M.; HULTER, L.; MULLER, C.; SCHMITT, E. Mast cells and inflammation. Archivum Immunologiae et Therapiae Experimentalis (Warsz), v. 50, n. 3, p. 179-185, 2002.

STIFELL, C.; IBAÑEZ, O. M.; RIBEIRO, O. G.; DECREUSEFOND, C.; SIQUEIRA, M.; MOUTON, D.; BIOZZI, G. Genetic regulation of specific and non-specific component of immunity. Immunology Letters, v. 16, p. 205-218, 1987.

TAL, M.; BENNETT, G. J. Extra-territorial pain in rats with a peripheral mononeuropathy: mechano-hyperalgesia and mechano-allodynia in the territory of an uninjured nerve. Pain, v. 57, p. 375-382, 1994. 
TANI, K.; OGUSHI, F.; KIDO, H.; KAWANO, T.; KUNORI, Y.; KAMIMURA, T.; CUI, P.; SONE, S. Chymase is a potent chemoattractant for human monocytes and neutrophils. Journal of Leukocyte Biology, v. 67, p. 585-589, 2000.

TEIXEIRA, C. F. P.; CURY, Y.; OLGA, S.; JANCAR, S. Hyperalgesia induced by Bothrops jararaca in rats: role of eicosanoids and platelet activating factor. Toxicon, v. 32, p. 419-426, 1994.

TEIXEIRA, C. F. P.; ZAMUNÉR, S. R.; ZULIANI, J. P.; FERNANDES, C. M.; CRUZHOFLING, M. A.; FERNANDES, I.; CHAVES, F.; GUTIÉRREZ, J. M. Neutrophils do not contribute to local tissue damage, but play a role in skeletal muscle regeneration, in mice injected with Bothrops asper snake venom. Muscle and Nerve, v. 28, p. 449-459, 2003.

TEIXEIRA, C.; CURY, Y.; MOREIRA, V.; PICOLO, G.; CHAVES, F. Inflammation induced by Bothrops asper venom. Toxicon, v. 54, p. 67-76, 2009.

THAKURDAS, S. M.; MELICOFF, E.; SANSORES-GARCIA, L.; MOREIRA, D. C, PETROVA, Y.; STEVENS, R. L.; ADACHI, R. The mast cell-restricted tryptase mMCP-6 has a critical immunoprotective role in bacterial infections. The Journal of Biological Chemistry, v. 282, p. 20809-20815, 2007.

TIDBALL, J. G. Inflammatory cell response to acute muscle injury. Medicine and Science in Sports and Exercise, v. 27, n. 7, p. 1022-1032, 1995.

TREBIEN, H. A.; CALIXTO, J. B. Pharmacological evaluation of rat paw oedema induced by Bothrops jararaca venom. Agents Actions, v. 26, p. 292-300, 1989.

VICARIO, M.; GUILARTE, M.; ALONSO, C.; YANG, P.; MARTINEZ, C.; RAMOS, L.; LOBO, B.; GONZÁlEZ, A.; GUILÀ, M.; PIGRAU, M.; SAPERAS, E.; AZPIROZ, F.; SANTOS, J. Chronological assessment of mast cell-mediated gut dysfunction and mucosal inflammation in a rat model of chronic psychosocial stress. Brain, Behavior, and Immunity, v. 24, p. 1166-1175, 2010.

VIGAR, N. D.; CABRERA, W. H.; ARAUJO, L. M. M.; RIBEIRO, O. G.; OGATA, T. R. P.; SIQUEIRA, M.; IBAÑEZ, O. M.; DE FRANCO, M. Pristane - induced arthritis in mice selected for maximal or minimal acute inflammatory reaction. European Journal of Immunology, v. 30, p. 431-437, 2000.

WAERN, I.; JONASSON, S.; HJOBERG, J.; BUCHT, A.; ABRINK, M.; PEJLER, G.; WERNERSSON, S. Mouse mast cell protease 4 is the major chymase in murine airways and has a protective role in allergic airway inflammation. Journal of Immunology, v. 183, p. 63696376, 2009.

WAERN, I.; KARLSSON, I.; THORPE, M.; SCHLENNER, S. M.; FEYERABEND, T. B.; RODEWALD, H. R.; ABRINK, M.; HELLMAN, L. PEJLER, G.; WERNERSSON, S. Mast cells limit extracellular levels of IL-13 via a serglycin proteoglycan-serine protease axis. Biological Chemistry, v. 393, p.1555-1567, 2012. 
WAERN, I.; LUNDEQUIST, A.; PEJLER, G.; WERNERSSON, S. Mast cell chymase modulates IL-33 levels and controls allergic sensitization in dust-mite induced airway inflammation. Mucosal immunology, v.6, p. 911-920, 2013.

WEISEL-EICHLER, A.; LIBERSAT, F. Venom effects on monoaminergic systems. Journal of Comparative Physiology, v. 190, n. 9, p. 683-690, 2004.

WERNERSSON, S.; PEJLER, G. Mast cell secretory granules: armed for battle. Nature Reviews Immunology, v. 14, p. 478-494, 2014.

YAN, X. J.; FENG, C. C.; LIU, Q.; ZHANG, L. Y.; DONG, X.; LIU, Z. L.; CAO, Z. J.; MO, J. Z.; LI, Y.; FANG, J. Y.; CHEN, S. L. Vagal afferents mediate anti-nociception of estrogen in a rat model of visceral pain: the involvement of intestinal mucosal mast cells and 5hydroxytryptamine 3 signaling. The Journal of Pain, v. 15, p. 204-217, 2014.

ZHANG, T.; FINN, D. F.; BARLOW, J. W.; WALSH, J. J. Mast cell stabilisers. European Journal of Pharmacology, v. 788, p. 158-168, 2016.

ZHAO, W.; OSKERITZIAN, C. A.; POZEZ, A. L.; SCHWARTZ, L. B. Cytokine production by skin-derived mast cells: endogenous proteases are responsible for degradation of cytokines. Journal of Immunology, v. 175, p. 2635-2642, 2005.

ZICHAR, B. C.; DALE, C. S.; DEMARCHI, D. S.; GONÇALVEZ, L. R. C. Contribution of metalloproteases, serine proteases and phospholipases A2 to the inflammatory reaction induced by Bothrops jararaca crude venom in mice. Toxicon, v. 55, p. 227-234, 2010. 